Illinois State University

ISU ReD: Research and eData

Theses and Dissertations

$6-24-2020$

\title{
The Beast And The Revival Of Rome: Mussolini And Rome In The Premillennial Imagination
}

Jon Stamm

Illinois State University, jon.stamm@icc.edu

Follow this and additional works at: https://ir.library.illinoisstate.edu/etd

Part of the History of Religion Commons, and the United States History Commons

\section{Recommended Citation}

Stamm, Jon, "The Beast And The Revival Of Rome: Mussolini And Rome In The Premillennial Imagination" (2020). Theses and Dissertations. 1312.

https://ir.library.illinoisstate.edu/etd/1312

This Thesis is brought to you for free and open access by ISU ReD: Research and eData. It has been accepted for inclusion in Theses and Dissertations by an authorized administrator of ISU ReD: Research and eData. For more information, please contact ISUReD@ilstu.edu. 
THE BEAST AND THE REVIVAL OF ROME: MUSSOLINI

AND ROME IN THE PREMILLENNIAL IMAGINATION

\section{JON STAMM}

\section{Pages}

Premillennial dispensationalism became immensely influential among American

Protestants who saw themselves as defenders of orthodoxy. As theological conflict heated up in the early $20^{\text {th }}$ century, dispensationalism's unique eschatology became one of the characteristic features of the various strands of "fundamentalists" who fought against modernism and the perceived compromises of mainline Protestantism. Their embrace of the dispensationalist view of history and Biblical prophecy had a significant effect on how they interpreted world events and how they lived out their faith. These fundamentalists established patterns of interpretation that in the second half of the $20^{\text {th }}$ century would fuel the emergence of a politically influential form of Christian Zionism. Improving the understanding of dispensationalist views on international affairs during the interwar period will help explain Christian Zionist development. This study will contribute to that understanding by addressing how premillennial dispensationalists viewed Italian dictator Benito Mussolini during the interwar period and explaining why he received so much attention.

Keywords: Mussolini, fundamentalism, premillennial dispensationalism, fascism, eschatology 
THE BEAST AND THE REVIVAL OF ROME: MUSSOLINI AND ROME IN THE PREMILLENNIAL IMAGINATION

JON STAMM

\author{
A Thesis Submitted in Partial \\ Fulfillment of the Requirements \\ for the Degree of \\ MASTER OF SCIENCE \\ Department of History \\ ILLINOIS STATE UNIVERSITY
}


C 2020 Jon Stamm 
THE BEAST AND THE REVIVAL OF ROME: MUSSOLINI AND ROME IN THE PREMILLENNIAL IMAGINATION

JON STAMM

COMMITTEE MEMBERS:

Andrew Hartman, Chair

Richard Soderlund

Stewart Winger 


\section{CONTENTS}

Page

CHAPTER I: INTRODUCTION

Premillennial Dispensationalism’s Origins and Growth 2

Explaining Fundamentalism and Modern Dispensationalism 6

Mussolini, Forgotten Antichrist $\quad 14$

Reporting the Signs of the Times

$\begin{array}{ll}\text { The Antichrist } & 19\end{array}$

CHAPTER II: THE RETURN OF ROME

The Empire Reestablished 39

$\begin{array}{ll}\text { Antichrists but not the Antichrist } & 47\end{array}$

The Romanization of Italy $\quad 56$

CHAPTER III: THE ANTICHRIST AND CENTRALIZATION 60

$\begin{array}{ll}\text { The Antichrist as Dictator } & 61\end{array}$

Economic Collectivization and the Antichrist $\quad 69$

CHAPTER IV: THE THREAT OF THE “ISMS”

Fascism as False Religion $\quad 88$

Fundamentalism, Fascism, and Modernity 93

Mussolini, Man of Mystery! $\quad 97$

The Great Harlot $\quad 106$

Mussolini, Jewish Fascist? 114

$\begin{array}{ll}\text { CHAPTER V: CONCLUSION } & 119\end{array}$

$\begin{array}{ll}\text { BIBLIOGRAPHY } & 122\end{array}$ 


\section{CHAPTER I: INTRODUCTION}

Premillennial dispensationalism became immensely influential among American

Protestants who saw themselves as defenders of orthodoxy. As theological conflict heated up in the early $20^{\text {th }}$ century, dispensationalism's unique eschatology became one of the characteristic features of the various strands of "fundamentalists" who fought against modernism and the perceived compromises of mainline Protestantism. Their embrace of the dispensationalist view of history and Biblical prophecy had a significant effect on how they interpreted world events and how they lived out their faith. These fundamentalists established patterns of interpretation that in the second half of the $20^{\text {th }}$ century would fuel the emergence of a politically influential form of Christian Zionism. Improving the understanding of dispensationalist views on international affairs during the interwar period will help explain Christian Zionist development. This study will contribute to that understanding by addressing how premillennial dispensationalists viewed Italian dictator Benito Mussolini during the interwar period and explaining why he received so much attention.

Dispensationalist preoccupations with Mussolini were primarily due to an unusual congruence between his personal characteristics and their eschatological expectations, further amplified by his relevance to some of the most intense anxieties that dispensationalists felt during this time period. This study will demonstrate that Mussolini's geography, imperial ambitions, political power, economic approach, ideology, atheism, relationship with the Catholic Church, and other personal characteristics seemed to not only line up with dispensationalist prophetic interpretations but mirrored some of their biggest apprehensions. 


\section{Premillennial Dispensationalism's Origins and Growth}

The first half of the $19^{\text {th }}$ century saw many new millenarian movements within American and British Protestantism that anticipated the imminent return of Christ, who would usher in a 1000-year reign of peace. Those who expected Christ's return before this "millennium" were called "premillennialists." While there were competing frameworks within this group, by far the most long-lasting and successful variant of premillennialism were the premillennial dispensationalists. They took the prophecies found in Old Testament books like Daniel and Ezekiel along with New Testament prophecies and applied them literally to the future. British pastor John Nelson Darby (1800-1882) divided history up into several “dispensations" and in each one "man is tested in respect of obedience to some specific revelation of the will of God" in a different way. ${ }^{1}$ Darby distinguished between Israel, who God used to bring about his earthly purposes, and the church, which had a spiritual purpose during the current dispensation. The world has been in the "church age" ever since Christ's death, which will end with the "rapture" when the church will be taken up to heaven. The church age has been a "great parenthesis" where prophetic events are in something of a holding pattern, but the rapture will mark the beginning of the end times when prophecies will be fulfilled. ${ }^{2}$ The rapture will be followed by a seven-year period of tribulation under control of the Antichrist, which will end as Christ returns, and following the battle of Armageddon, sets up a 1000-year kingdom that precedes the final judgement. ${ }^{3}$

\footnotetext{
${ }^{1}$ C.I. Scofield, ed., Scofield Reference Bible (New York: Oxford University Press, 1909), 5. Quoted in Timothy P. Weber, Living in the Shadow of the Second Coming: American Premillennialism, 1875-1982 (Chicago: University of Chicago Press, 1987), 17.

${ }^{2}$ Weber, Living in the Shadow, 20-21.

3 Matt Avery Sutton, American Apocalypse: A History of Modern Evangelicalism (Cambridge, MA: Belknap Press of Harvard University Press, 2014), 18-19.
} 
By the 1870s premillennial dispensationalism had a foothold in the United States and over the next few decades gained support through books and sermons of popular preachers like Dwight Moody and William E. Blackstone. The 1909 publication of C.I. Scofield's Scofield Reference Bible solidified the status of dispensationalism among Protestant theological conservatives as many Bible readers unwittingly imbibed its interpretations and given the layout of the pages, possibly confused the canonized scripture with the commentary. ${ }^{4}$

Dispensationalism became closely linked to the fundamentalist movement that emerged in the 1920s in response to Biblical higher criticism, modernism, and the Social Gospel. Not all fundamentalists were dispensationalists, but nearly all dispensationalists were fundamentalists. Fundamentalism has been described as the "public expression" of this theological perspective during that time period. ${ }^{5}$

Dispensationalism was also the dominant eschatological viewpoint of the new and rapidly growing Pentecostal movement in the United States. Pentecostalism, which embraced and encouraged tangible manifestations of the Holy Spirit like speaking in tongues and healing, exploded after William Seymour initiated the Azusa Street revival of 1906 in Los Angeles. The Pentecostal movement shared a similar theological genealogy to fundamentalists, which included the Wesleyan holiness movement and the Keswick "higher life" conferences. ${ }^{6}$ They shared the fundamentalist view of Biblical authority but saw a much larger role for the Holy Spirit's direct communication to individuals.

\footnotetext{
${ }^{4}$ Robert C. Fuller, Naming the Antichrist: The History of an American Obsession (New York: Oxford University Press, 1995), 125.

${ }^{5}$ Sutton, American Apocalypse, 82.

${ }^{6}$ Grant Wacker, Heaven Below: Early Pentecostals and American Culture (Cambridge, MA: Harvard University Press, 2001), 2-3.
} 
For example, in an article partly addressing the Washington Naval Conference, a Pentecostal author said that he asked the Lord for guidance on understanding the significance of the Four-Power Treaty. He claimed that the word "Make-Believe" flashed into his mind, telling him that these human attempts at peace would fail. ${ }^{7}$ While most fundamentalists at the time came to the same conclusion and were capable of equal levels of subjectivity, they would have found his method too untethered to Biblical exegesis for their comfort.

Regarding eschatology, Grant Wacker argues that Pentecostals "assumed the basic framework of premillennial dispensationalism" even as they made minor modifications, including the belief that only Pentecostals would be raptured before the tribulation. ${ }^{8}$ While Pentecostals thought their less lively fundamentalist cousins would have to suffer through the tribulation, fundamentalists published books and pamphlets questioning the legitimacy of Pentecostal theology, their understanding of the "gifts of the spirit," and even the source of the miraculous manifestations that they claimed. Leading dispensationalist writer Arno Gaebelein called it a "counterfeit movement" that drew in "simple-minded and untaught Christians" and reported feeling a "strange power" in the presence of Pentecostals. He compared it to $19^{\text {th }}$ century Spiritism and possibly belied a discomfort with the racially integrated nature of early Pentecostalism when he traced its origins to "a small meeting of excited colored people in Los Angeles" that started a "religious frenzy."

\footnotetext{
${ }^{7}$ Arthur W. Frodsham, "The Return of the Lord," Pentecostal Evangel, February 18, 1922, 7. See Wacker, Heaven Below, 81-84 for a discussion of the various ways Pentecostals believed the Holy Spirit could communicate with them.

${ }^{8}$ Wacker, Heaven Below, 253.

${ }^{9}$ Arno Gaebelein, Half a Century: The Autobiography of a Servant (1930; repr.; New York: Garland Publishing, 1988), 177; Arno Gaebelein, The Hope of the Ages: The Messianic Hope in Revelation, in History and in Realization (New York: Our Hope, 1938), 176.
} 
Fundamentalism and Pentecostalism can be usefully classified both as distinct groups or together under a broader Evangelical umbrella, depending on what topic is being considered. Since the disagreements and acrimony between the two groups did not make a significant difference in their interpretive conclusions regarding world events, this study will draw on both fundamentalist and Pentecostal sources. The extensive cross referencing between fundamentalist and Pentecostal publications would seem to indicate that there was significant overlap in what they were reading. This study will emphasize what passed for mainstream interpretations within each of these groups. Some of the more controversial religious figures of the time period, including Pentecostal Aimee Semple McPherson and renegade fundamentalist Gordon Winrod were not always welcome among the leaders of these wider movements but also were dispensationalist in their eschatology. They did interact with the mainstream at different periods of their career and contributed to the public conversation regarding Mussolini, so their publications will be examined as well. ${ }^{10}$

Dispensationalist eschatology attributed a great deal of importance to the restoration of Israel and already in the late $19^{\text {th }}$ century prominent American dispensationalists were advocating for the establishment of a Jewish nation in Palestine. Although their views of Judaism were somewhat ambivalent during the interwar years and their public advocacy waxed and waned, they never quit closely watching events in the Holy Land. After Israel became a nation-state in 1948, dispensationalists were some of its most ardent supporters, which only intensified in light of Israel's stunning success in the 1967 Six Day War. ${ }^{11}$ Dispensationalism spawned a powerful political movement that focused on supporting Israel, surfacing in the 1970s

\footnotetext{
${ }^{10}$ In his autobiography the prominent dispensationalist preacher Arno Gaebelein fondly recalls spurning Aimee Semple McPherson when she attended one of his talks. Gaebelein, Half a Century, 210.

${ }^{11}$ Yaakov Ariel, "Israel in Contemporary Evangelical Christian Millennial Thought," Numen: International Review for the History of Religions 59 (2012): 467.
} 
along with the broader emergence of the Religious Right. ${ }^{12}$ This movement has often been referred to as "Christian Zionism," an unfortunately imprecise term that has also been applied to earlier mainline Protestant support for Israel that was not dispensationalist in its theological outlook. While "Evangelical Zionism" or "Fundamentalist Zionism" might be more accurate, to stay consistent with the literature this paper will use Christian Zionism to refer to the more recent, largely dispensationalist influenced movement.

\section{Explaining Fundamentalism and Modern Dispensationalism}

The American history of premillennial dispensationalism overlaps with that of American fundamentalism. Given the extensive embrace of dispensationalism by fundamentalists, many works on fundamentalism are essentially histories of premillennial dispensationalism, even if the earliest scholars downplayed the importance of eschatology. For nearly fifty years after the Scopes Monkey Trial, fundamentalists were depicted as deprived, mostly rural, and uneducated rubes whose opposition to change was pathological.

Stewart Cole was the first to attempt a history of the movement in 1931 and set the tone for subsequent scholars. Cole counted some of the most influential American liberal theologians of the early $20^{\text {th }}$ century as advisors, including Shailer Matthews. Matthews was the Dean of the Divinity School at the University of Chicago and his critiques of fundamentalism put him at the center of the Modernist/Fundamentalist controversies of the day. Cole describes his History of Fundamentalism as a "psychological study" even though most of the value of the work lies in its organizational history. ${ }^{13}$ The psychological analysis is limited to pejorative assertions lacking in empirical support. Fundamentalists are described as "malcontents," "disturbed," "maladjusted,"

\footnotetext{
12 Timothy Weber, On the Road to Armageddon: How Evangelicals Became Israel's Best Friend (Grand Rapids, MI: Baker Academic, 2004), 184-187, 199.

${ }^{13}$ Stewart G. Cole, The History of Fundamentalism, (Eugene, OR: Wipf and Stock, 1931), xi.
} 
and "pathological," while liberals are invariably "[h]ealthy-minded," "[a]dventerous," "forwardlooking," and "courageous." Fundamentalism is often described as "cult" that "rested their religion on a foundation of an uncritical piety" while liberals "established harmonious adjustment with their world." ${ }^{14}$ Cole does make the potentially useful point that fundamentalist commitment to their beliefs had a significant emotional component, but the concrete evidence is scarce, and he implies that the heroic liberals are immune to such influences as they fearlessly subject their theological positions to cold-blooded scrutiny. Cole claims that students in fundamentalist Bible institutes have a "passion for saintliness [that] often leads to near hysteria. The constant nervous strain due to exaggerated beliefs in the inner working of the Holy Spirit and the imminence of the Second Coming tend to provoke a psychopathic condition in the devotee." 15 Given the overall tone of the work and lack of substantiating evidence, this sounds suspiciously like either the reaction he would expect to result from those beliefs or a fundamentalist caricature of Pentecostalism. He describes fundamentalist theology as "mediaeval," which illustrates not only an ignorance of either mediaeval or fundamentalist theology but also shows that he recognizes nothing new in fundamentalism. ${ }^{16}$ This is a common misconception held not only by liberal scholars of this era, but of the fundamentalists themselves, who insisted they were holding on to timeless truths, rather than relatively recent innovations.

Another emphasis of early scholarly appraisals of fundamentalism that would later be challenged was their ideas about its geographic and socio-economic characteristics. Cole argued that the revivalism that influenced fundamentalists was primarily successful among the "rural-

\footnotetext{
${ }^{14}$ Cole, History of Fundamentalism, 138, 336, 282, xii, 28, 29, 138, 334, 52, 335.

${ }^{15}$ Cole, History of Fundamentalism, 250.

${ }^{16}$ Cole, History of Fundamentalism, 52.
} 
minded and the discontented masses in large metropolitan regions." ${ }^{17}$ Rural, Southern, and poor became tightly linked with fundamentalism, probably partly due to impressions formed by the Scopes Monkey Trials. Even a scholar as gifted as H. Richard Niebuhr saw the Protestant divide "as a conflict between urban and rural religion," contrasting "rural Fundamentalism with bourgeoise Modernism." 18

In 1963 Norman Furniss's The Fundamentalist Controversy, 1918-1931 showed that not much had changed in the subsequent thirty years regarding the historiography of fundamentalists. Like his predecessors, he focused on organizations and individuals at the expense of fundamentalist ideas. When their beliefs were addressed they were portrayed as "static habits of thought" or "familiar doctrines" and he was focused on the issues of evolution and modernism more generally. ${ }^{19}$ Eschatology is completely absent in his account. Furniss also reinforces the rural, low income image of fundamentalists. He does express some doubt regarding Neibuhr's more economic understanding of rural/urban tensions but instead he just attributes rural fundamentalism to a lack of education. While Furniss was not as explicitly psychological in his approach, he mostly reinforces Cole's conclusions, attributing negative personality characteristics to fundamentalists rather than exploring their theological commitments. In a chapter on the "Characteristics of the Fundamentalists" we learn that "[v]iolence in thought and language," "ignorance, even illiteracy," "anti-intellectualism," "vaguely defined fear," "egotism," sentimentality, and concern for children were all important features. ${ }^{20}$ In fact, their egotism was a major motivation for their opposition to evolution, as the

\footnotetext{
${ }^{17}$ Cole, History of Fundamentalism, 38.

${ }^{18}$ H. Richard Niebuhr, The Social Sources of Denominationalism (1929; repr.; Cleveland: Meridian Books, 1965), 184-186.

${ }^{19}$ Norman F. Furniss, The Fundamentalist Controversy, 1918-1931 (Hamden, CN: Archon Books, 1963), 15-16.

${ }^{20}$ Furniss, Fundamentalist Controversy, 35-44.
} 
fragile pride of "the poverty-stricken farmer of Tennessee, the restless inhabitant of a

Minneapolis tenement, and the unsuccessful preacher of New York" felt attacked by the idea that they descended from apes. ${ }^{21}$

One additional feature of scholarly understanding that developed after Cole's account was that fundamentalism was a short-lived outburst that quickly faded into irrelevance. Furniss argues that fundamentalism began to decline after the Scopes Monkey Trials and the death of William Jennings Bryan, whom he attaches more importance to than subsequent scholars do. The dissemination of knowledge made fundamentalist appeals less convincing and, in his view, no one could replace The Great Commoner as a leader. Cole measures the decline of "aggressive fundamentalism" by the amount of anti-evolutionist agitation. He cites a shifting focus to anti-wet campaigning as proof. ${ }^{22}$ This is an unnecessarily narrow definition of fundamentalism and it is unclear why aggressive agitation to maintain prohibition is evidence of decline. $^{23}$

Earnest Sandeen's The Roots of Fundamentalism, published in 1970 was a turning point in the historiography of fundamentalism. Sandeen challenges not only the rural, Southern, lower-class stereotypes but the overall approach of the more strictly sociological explanations that had dominated academic interpretations of fundamentalism up to that point. He argues that theology needs to be taken seriously as an independent variable. Sandeen sees premillennial dispensationalism as a defining feature of fundamentalism, a viewpoint shared currently by Matthew Avery Sutton, who argues that fundamentalism is "best defined as radical apocalyptic

\footnotetext{
${ }^{21}$ Furniss, Fundamentalist Controversy, 44.

${ }^{22}$ Furniss, Fundamentalist Controversy, 178-180.

${ }^{23}$ This narrowness apparently affected his use of primary sources. He dismisses The King's Business as "of no value." This magazine is widely recognized by scholars of fundamentalism as one of the best sources for fundamentalist thinking during the interwar period. This comment is found in Furniss, Fundamentalist Controversy, 186.
} 
evangelicalism."24 George Marsden, probably the most prolific scholar of American fundamentalism over the last 40 years, does not draw those theological boundaries as narrowly as Sandeen and Sutton, as he includes non-dispensationalist theological conservatives as central figures in the fundamentalist movement. Marsden also takes fundamentalist theology seriously as an explanatory variable, but he explicitly casts doubt on Sandeen's view that premillennial dispensationalism was "the decisive influence" on fundamentalist ideas. ${ }^{25} \mathrm{He}$ argues for a broader set of cultural and intellectual influences that preceded the dominance of dispensationalism, including "Scottish Common-Sense Realism" and the holiness movement. For him, what ultimately bound fundamentalists together was their belief-based opposition to modernism. ${ }^{26}$ Marsden's approach is more comprehensive, but this study will focus on the dispensationalists studied by Sandeen and Sutton since eschatology plays a big part in explaining fundamentalist interest in Mussolini.

There is now widespread agreement that the imminent expectation of the second coming did not lead to a quietist fatalism for those early dispensationalists. The "now-not yet tensions" inherent in their ideology provided a powerful impetus for evangelization and social action. It may have been logically inconsistent at times and certainly appeared so to their liberal counterparts, but they believed that even though God's plans had been determined long ago they had an obligation to "occupy" until his return. ${ }^{27}$ Occupying always entailed evangelization and maintaining personal piety, but sometimes it also meant doing what one could to limit the evil in society. There is some disagreement as to whether or not fundamentalists have consistently tried

\footnotetext{
${ }^{24}$ See, respectively, Ernest R. Sandeen, The Roots of Fundamentalism: British and American Millenarianism, 18001930 (1970; repr., Chicago: University of Chicago Press, 2008), xi, xv; Sutton, American Apocalypse, 3.

${ }^{25}$ George Marsden, Fundamentalism and American Culture, $2^{\text {nd }}$ ed. (New York: Oxford University Press, 2006$), 7$.

${ }^{26}$ Marsden, Fundamentalism, 4, 14-16, 102.

${ }^{27}$ Weber, Living in the Shadow, 64.
} 
to shape the society outside the boundaries of their own movement. Marsden represents the onceconsensus view that fundamentalism was relatively insular and focused on institution building between the disgrace of the 1925 Scopes Monkey Trial and the emergence of neo-evangelicalism after World War II. ${ }^{28}$ This consensus was challenged by Matthew Avery Sutton. Sutton argues that this view is the result of a falsehood propagated by evangelicals who successfully rebranded themselves to escape from the fundamentalist stigma by mischaracterizing interwar fundamentalists as reclusive and insufficiently engaged. Sutton claims fundamentalists may have had less national influence during that period, but they never stopped trying to shape the world around them, and that energetic engagement was fueled by their apocalyptic premillennial dispensationalism. ${ }^{29}$

Studies specifically focusing on premillennial dispensationalism were almost completely absent until the 1980s, when it became apparent that these "Christian Zionists" were becoming a significant political force in the United States. Norman Krause's Dispensationalism in America (1963) was the most important earlier contribution. While Krause's work was more narrowly focused than Sandeen's and that of subsequent scholars of fundamentalism, he anticipates Sandeen by arguing that dispensationalism "made up the vanguard of the modern fundamentalist movement." ${ }^{30}$ Krause's account emphasizes the theological developments early in the movement. He argues that despite their claims of continuity with the historic church, dispensationalism was an innovation that was informed by theological assumptions that included "a rigid theory of verbal and plenary inspiration, the absolute depravity of man and his helplessness to assist in his own salvation, and the sovereign transcendence of the triune God." 31

\footnotetext{
${ }_{28}$ Marsden, Fundamentalism, 6, 191-194.

${ }^{29}$ Sutton, American Apocalypse, 294.

${ }^{30}$ Norman Krause, Dispensationalism in America (Richmond, VA: John Knox Press), 7.

${ }^{31}$ Krause, Dispensationalism in America, 45, 61.
} 
This understanding of inspiration led not to epistemological caution when interpreting scripture but rather to the conclusion that every word could be read literally (including in the Authorized English translation) and understood clearly by anyone, as long as they were guided by the Holy Spirit. Krause also recognizes that the pessimism of dispensationalists does not often lead to passivity and inaction. ${ }^{32}$ He ends his history with Scofield's role as a popularizer who played a big role in solidifying the basic framework of the dispensationalist interpretive system. This is understandable in a work like this that is meant to establish the theological origins of dispensationalism but unfortunately seemed to set a precedent regarding what eras were deemed worthy of attention.

In the 1980s the rise of the Religious Right, its pro-Israel foreign policy, and the election of a President who would occasionally cite obscure prophetic verses in his conversations led to a big increase in popular and scholarly attention to modern premillennial dispensationalism and its origins. While historians of fundamentalism have given the interwar era the attention it deserves, the more narrowly focused studies of recent Christian Zionism have largely neglected it. The typical treatment discusses dispensationalists' $19^{\text {th }}$ century beginnings and then jumps past the interwar era before touching briefly on the effect of Israel's 1948 establishment and then moving on to the period following the Six Day War. ${ }^{33}$

The now extensive scholarship on Christian Zionism has a variety of emphases. The theology, the political participation, and through recent ethnographic work, the culture of this movement has been examined. There is a consensus on the importance of premillennial dispensationalism as the theological framework that has most heavily influenced their political

\footnotetext{
${ }^{32}$ Krause, Dispensationalism in America, 65-66, 73-75.

${ }^{33}$ See Jan Nederveen Pieterse, "The History of a Metaphor: Christian Zionism and the Politics of the Apocalypse," Archives de Sciences Sociales des Religions 75 (1991): 91, https://www.jstor.org/stable/30116133.
} 
activity and most accounts include the $19^{\text {th }}$ century theological developments described above, although the theological detail is limited in the more politically focused works. But even the scholars stressing theology often skip from 1900 to 1970, leaving the impression that no important theological innovations happened in between. ${ }^{34}$

The scholars more interested in the political aspect of the movement spend more time on the ways that important figures in the Religious Right developed relationships with both conservative American politicians and Israel's government. ${ }^{35}$ Victoria Clark and Stephen Spector have both not only studied the higher level political interactions but spent a great deal of time with rank and file pro-Israel Zionists, going to churches and conferences, conducting interviews and in Clark's case, going on a tour to the Holy Land. While Clark's account mostly reinforces the primacy of eschatology (and the "fear-filled fundamentalist mindset"), Spector argues that the motivations for modern-day dispensationalist political activities are more complex and varied than normally portrayed. He found that many were motivated by noneschatological but still theological considerations like God's promise to bless those who bless Israel and the belief that God promised the Holy Land to the offspring of Sarah (Jews), not the offspring of Hagar (Arabs). He also found many who were motivated by guilt over the Church's historic mistreatment of Jews or filled with gratitude at the role that the Jewish people played in God's plan of salvation. ${ }^{36}$ Almost every author explained how the beliefs of this movement have

\footnotetext{
${ }^{34}$ See Stephen Sizer, Zion's Christian Soldiers? The Bible, Israel and the Church (Nottingham: Inter-Varsity Press, 2007); Dan Cohn-Sherbok, The Politics of Apocalypse: The History and Influence of Christian Zionism (Oxford: Oneworld, 2006).

${ }^{35}$ Grace Halsell, Prophecy and Politics: Militant Evangelists on the Road to Nuclear War (Westport, CN: Lawrence Hill and Company, 1986); Clifford A. Kiracofe, Dark Crusade: Christian Zionism and U.S. Foreign Policy (New York: I.B. Tauris, 2009).

${ }^{36}$ Victoria Clark, Allies for Armageddon: The Rise of Christian Zionism (New Haven: Yale University Press, 2007), 289; Stephen Spector, Evangelicals and Israel: The Story of American Christian Zionism (New York: Oxford University Press, 2009), 23-34.
} 
been widely popularized via mass media over the last 50 years, including radio, television, film, and especially books. Hal Lindsey's 1970 The Late Great Planet Earth is universally mentioned as a landmark literary contribution that kickstarted the more politically active phase. ${ }^{37}$

This study will start to fill in the chronological gap in the historiography of today's politically active premillennial dispensationalists by examining how their predecessors viewed international events, paying close attention to their eschatology, but informed by Spector's more multi-causal approach, also trying to identify how those interpretations interacted with their other concerns.

\section{Mussolini, Forgotten Antichrist}

There was no shortage of international news that fired the dispensationalist imagination during the interwar period. This included the threat of Communism and the spread of Fascism. This study will show that one figure uniquely endowed with characteristics that sent premillennialist speculations into overdrive was Italy's dictator, Benito Mussolini. Postwar upheaval in Italy led to a growing Fascist movement headed by Mussolini, who was appointed Prime Minister in 1922 and used intimidation to rapidly consolidate both Fascist control and his own personal power. ${ }^{38}$

While this study does not attempt any novel interpretations of Mussolini or Fascism it intends to fill out the small historiography of Mussolini's American reception history. John Patrick Diggins wrote the definitive account his 1972 study Mussolini and Fascism: The View from America, addressing the response from American labor unions, big business, Italian Americans, journalists, intellectuals, political groups, the government, and religious groups. His account of American religion understandably focused on American Catholicism's response to

\footnotetext{
${ }^{37}$ Hal Lindsey, The Late, Great Planet Earth (Grand Rapids, MI: Zondervan, 1970).

38 Denis Mack Smith, Mussolini (New York: Alfred A. Knopf, 1982), 62-68.
} 
Mussolini but also addressed American Protestantism. Almost all of the material on

Protestantism focused on mainline and liberal Protestantism and much of his analysis was drawn from The Christian Century. There was one paragraph on fundamentalists, citing six somewhat random sources. Diggins mentioned that some thought he was the Antichrist, attributing their concern to anti-Catholicism. ${ }^{39}$

Scholars of early American fundamentalism have touched on how dispensationalists viewed Mussolini when he was in power, although in works with much broader scopes than this one, only spending a few pages on him. ${ }^{40}$ There is not much variation in their accounts. Mussolini inspired widespread interest from dispensationalists. Some were convinced he was the Antichrist figure that they had been watching for, others saw him as paving the way for a future Antichrist, and the more circumspect withheld judgement. Given the scope of their research, these scholars understandably did not dig as deeply into the explanations for this fascination. They agreed that his position as the head of Italy was significant and Timothy Weber briefly mentioned that his charisma, military ambitions, and relationship with Catholicism also fit their expectations. ${ }^{41}$

Scholars of Christian Zionism have attempted to map and compare the various and changing interpretations made by dispensationalists of nations and their leaders with great detail, but they have overwhelmingly focused on the era since 1967. When they have taken a longer view it has focused on the role of Israel and Russia, whose perceived importance by

\footnotetext{
39 John Patrick Diggins, Mussolini and Fascism: The View from America (Princeton: Princeton University Press, 1972), 200-201.

${ }^{40}$ Sutton, American Apocalypse, 213-219; Weber, Living in the Shadow, 178-182; Joel Carpenter, Revive Us Again: The Reawakening of American Fundamentalism (New York: Oxford University Press, 1997), 92-94.

${ }^{41}$ Weber, Living in the Shadow, 178-179.
} 
dispensationalists has been consistent over time. ${ }^{42}$ They have written extensively on other post1967 areas of emphasis, like the Arab world and Iran but rarely mention earlier dispensationalist preoccupations. ${ }^{43}$ Weber is a notable exception since his earlier work focusing on the origins of dispensationalism positioned him to recognize the relevance of the interwar period to its current, more political manifestation. He briefly touched on Mussolini and other interwar issues in his study of the development of Christian Zionism, but even that scant treatment was an outlier. ${ }^{44}$ An unscientific but plausibly representative sample of six other books that did cover Christian Zionism's theological history only evinced one mention of Mussolini. ${ }^{45}$ It claimed in passing that he was considered by some as a candidate for the Antichrist, "but only briefly." 46 What constitutes brevity is debatable but the amount of sustained interest in Mussolini that this study will demonstrate relative to the length of time he spent on the world's stage challenges the accuracy of this statement.

The dispensationalist attitude towards Mussolini is an understudied topic in its own right and this study will reinforce but significantly add to Weber's explanation for their interest. It will provide some detail to the fundamentalist historiography of that era and help fill in a prominent gap in understanding current forms of politically involved dispensationalism. Like Sandeen and Sutton I take the beliefs of dispensationalists seriously as an independent variable. As important as that eschatological framework was however, the way dispensationalists applied

\footnotetext{
42 Dwight Wilson, Armageddon Now! The Premillenarian Response to Russia and Israel Since 1917 (Grand Rapids, MI: Baker Book House, 1977).

${ }^{43}$ See Tristan Sturm, "Imagining Apocalyptic Geopolitics: American Evangelical Citationality of Evil Others," in Mapping the End Times: American Evangelical Geopolitics and Apocalyptic Visions, ed. Jason Dittmer and Tristan Sturm (Burlington, VT: Ashgate, 2010), 133-154.

${ }^{44}$ Weber, On the Road to Armageddon, 88-91.

${ }^{45}$ The books include Sizer, Zion's Christian Soldiers; Cohn-Sherbok, Politics of Apocalypse; Kiracofe, Dark Crusade; Spector, Evangelicals and Israel; Clark, Allies for Armageddon; Halsell, Prophecy and Politics.

${ }^{46}$ Clark, Allies for Armageddon, 139.
} 
that framework to real world events was shaped by factors that were not always directly eschatological or even always theological. Dispensationalists thought they saw many similarities between Mussolini and the Antichrist figure they expected. Furthermore, those characteristics also reflected anxieties that dispensationalists expressed throughout their publications in this time period. These findings support the eschatological emphasis of previous work on both early fundamentalism and the more recent politically engaged Christian Zionism but avoids reductionism by demonstrating how that eschatology interacted with other dispensationalist social concerns.

\section{Reporting the Signs of the Times}

Scholars of dispensationalism have often emphasized the importance of books and periodicals, and scholars of fundamentalism more generally have relied on those sources to understand the 1920s and 1930s. While dispensationalist books of this time period did not begin to approach the more recent sales of Hal Lindsey's many books or Tim Lahaye's fictional Left Behind series, there was a significant market for books trying to connect international events to prophecy. Maybe more importantly, there were many periodicals issued by Bible colleges, parachurch organizations, and influential preachers that included extensive prophetic speculation. Joel Carpenter argues that these magazines were "the principle media for fundamentalist discourse" during this time period and he identified the most influential ones, including The King's Business and The Moody Bible Institute Monthly (MBIM). ${ }^{47}$ I will be relying heavily on the magazines and books of the time to understand what dispensationalist leaders were saying and what the rank and file were reading. Some of these magazines were devoted almost exclusively to prophecy while others had a wider variety of subject matter. But

\footnotetext{
${ }^{47}$ Carpenter, Revive Us Again, 25-26.
} 
even in those with greater breadth, prophetic articles appeared to be some of the most popular. The editors often announced upcoming series on prophetic topics and felt the need to explain the absence of popular contributors of that genre. Readers requested so many back copies of a Pentecostal Evangel article on the prophetic significance of Italy's invasion of Ethiopia that the magazine ran out and had to publish an apology to their disappointed readers, since the type was already destroyed. One reader wrote $M B I M$ asking if one could take prophecy too seriously and was assured that was not possible. ${ }^{48}$

Mussolini's rise to power almost immediately caught the attention of premillennial dispensationalists and from the beginning they saw eschatological implications. Louis Bauman, a prominent dispensationalist preacher and prolific writer of prophetic speculation, claimed that he started looking at Mussolini as "the world's foremost candidate for the job of the Antichrist" as soon as he came to power in 1922. As early as 1923, a MBIM article on Mussolini claimed that for "those of us who are Bible students every move is full of meaning" and connected happenings in Italy to John's vision in Revelation. ${ }^{49}$ By the middle of the 1920 s, this interest became widespread and the perceived connections between Mussolini and prophecy started to be spelled out more explicitly in dispensationalist magazines, books, and pamphlets. This continued unabated through the late 1930s. Between 1927 and 1933 there were more columns written on Mussolini in Gerald Winrod's Defender than "any other world figure." ${ }^{\circ 0}$ One internal

\footnotetext{
${ }^{48}$ See, respectively, Unknown, “Dr. Bauman's Articles," King's Business, February 1932, 51; Unknown, "Ethiopia Versus Italy," Pentecostal Evangel, November 16, 1935, 9; Grant Stroh, Practical and Perplexing Questions, Moody Bible Institute Monthly, March 1938, 374.

49 Louis S. Bauman, "The Reappearance of the Empire on the Fateful Hills of Rome," King's Business, July 1936, 257; Mrs. Gilbert Potter, "Will Mussolini and the Pope Join Forces?" Moody Bible Institute Monthly, November 1923, 110.

${ }^{50}$ Leo P. Ribuffo, The Old Christian Right (Philadelphia: Temple University Press, 1983), 100.
} 
critic of all the speculating claimed that "hundreds of the Premillenarians" had identified Mussolini with the Antichrist. ${ }^{51}$

As the above quotes demonstrate, much of the dispensationalist interest in Mussolini was related to their view of the mysterious Antichrist figure that was to play a role in end-times prophecy. Before we get to the explanations for why they connected Mussolini with the Antichrist, it is necessary to get some historical background regarding how this evil personage has been understood.

\section{The Antichrist}

The term "Antichrist" is only mentioned three times in the Bible, all in the letters of John, but the concept of the Antichrist has long generated intense interest among Christians. When those verses in the Johannine Epistles are read in isolation they do not seem to justify the body of interpretation that has developed around the concept. I John 2:18 says " ... as ye have heard that antichrist shall come, even now there are many antichrists, by which we know that it is the last time." I John 2:22 says "Who is a liar but he that denieth that Jesus is the Christ? He is antichrist that denieth the Father and the Son." In 2 John 7, after calling those who deny that Christ came in the flesh "deceivers" the author says "...This is a deceiver and an antichrist." In all of these verses the term is used to stigmatize those who have broken away from the Christian community that John is addressing. Only in the first verse mentioned is there a hint that there was some expectation of a specific figure that would come in the future. Various modern commentators disagree over whether this first mention refers to a more diffuse opposition or to a distinct

\footnotetext{
51 J.C. O'Hair, "Mussolini-Ethiopia-And Us," Bible Study for Bereans, October 1935, https://www.bereanbiblesociety.org/mussolini-ethiopia-and-us/.
} 
personality. ${ }^{52}$ Nevertheless, the Antichrist concept has a history that not only predates dispensationalism but also the Protestant Reformation.

Early church theologians disagreed over whether the Antichrist was Satan or a distinct person that would act on his behalf before Christ's return. By the fourth century, the latter interpretation became almost unchallenged among theologians with a more apocalyptic emphasis. The debate became more about how literally to read prophetic books like Revelation. Augustine advocated a more symbolic understanding where the Antichrist stood in for a more generalized opposition to God. This view has persisted in Catholicism and many strands of Protestantism today. But the more literal apocalyptic perspective of the Antichrist never entirely disappeared and reemerged throughout Christian history in response to various threats, including the sudden growth of Islam. ${ }^{53}$

Proto-Protestants like John Wycliffe and John Huss accused the Pope of being the Antichrist and unsurprisingly Protestant Reformers saw the Roman Catholic Church as part of the Antichrist's conspiracy. Although they rarely identified a particular Pope as the evil one, they believed the Antichrist would emerge out of Rome. During the American Revolutionary War, some religious-minded American Protestants saw the British Empire as a weapon of the Antichrist and in the 1790s the violence and anti-religious nature of the French Revolution led some Protestants to see a Satanic role being played by Freemasons, who were infiltrated by agents of the Bavarian Order of the Illuminati. ${ }^{54}$ While the British Empire mostly disappeared from American Protestant apocalyptic thinking, the Illuminati never completely did and the

\footnotetext{
${ }^{52}$ David Jackman, The Message of John's Letters (Downers Grove, II: Intervarsity Press, 1988), 69.

${ }^{53}$ Fuller, Naming the Antichrist, 31-33.

${ }^{54}$ Fuller, Naming the Antichrist, 37; James Alan Patterson, "Changing Images of the Beast: Apocalyptic Conspiracy Theories in American History," Journal of the Evangelical Theological Society 31, no. 4 (December 1988): 443-447.
} 
interest paid to the Catholic Church fluctuated, depending on domestic conditions and international events. ${ }^{55}$

Dispensationalists drew on this long tradition of Christian apocalyptic thought in the way they viewed the Antichrist, but their complicated system of interpretation emboldened them to assert a level of understanding that was unprecedented. Dispensationalists associated the Antichrist with other Biblical references to a powerful evildoer who would consolidate immense power during the end times in an ultimately failed attempt to defy God and destroy His people. In Daniel 9:26 a "prince that shall come" is prophesied to destroy Jerusalem, 2 Thessalonians 2:2 tells of a "man of sin" that will attempt to exalt himself as God, and Revelation 13:1 tells of a "beast" that will arise out of the sea and become a powerful ruler for a short time, to give just a few examples. To dispensationalists these references by different authors in different times are describing the same figure from their respective prophetic vantage points. The Scofield Reference Bible makes these connections explicit using commentary that accompanies the original text and "subject chain references" that link the topic of a given verse to relevant verses elsewhere. ${ }^{56}$

Most powerful and aggressive international figures that posed a threat to the United States caught the attention of American dispensationalists who were watching the signs of the times closely. Germany’s Kaiser Wilhelm was never as close to provoking an Antichristrelevant consensus as Mussolini would be but during the Great War there were dispensationalists who thought his ambitions and actions were prophetically significant. Since Germany was

\footnotetext{
55 In 1991 Larry Burkett, the foremost Evangelical financial advisor at the time, published a popular work of fiction where the Illuminati orchestrates the ascendance of an Antichrist-like figure: The Illuminati, (Nashville: Thomas Nelson, 1991).

${ }^{56}$ For a typical interpretation see Alva J. McClain, "Daniel's Prophecy of the 70 Weeks," The King's Business, July 1939, 256-257. For an explanation of how readers were to use these chain references see C.I. Scofield, ed., The New Scofield Reference Holy Bible, rev. ed. (New York: Oxford University Press, 1967), xiv.
} 
perceived as the source of the liberal theology that was so despised by fundamentalists, the militarily aggressive leader of that country made an appealing target.

Immediately after the onset of the war James Gray, the dean of Moody Bible Institute, asked in the subtitle of an article: "Will the Kaiser Develop into the World Emperor and is the Antichrist Kingdom to be Realized With-in the Next Few Months?" He extensively discussed how closely the Kaiser's characteristics matched the coming Antichrist, citing his bellicosity, boastfulness, and tendency towards "double-dealing" as favorable indications. Wilhelm's geographical origins were problematic and partially explains why he never reached Mussolini's status among dispensationalists, for eschatological reasons discussed below. Gray said it would be surprising if the Antichrist came from Germany but did not rule it out. ${ }^{57}$

Many thought he was a malevolent person but stopped short of directly tying him to the Antichrist figure. The King's Business thought the Kaiser was a threat but was more concerned with the role that the Catholic Church was playing behind the scenes, an issue that Gray also mentioned. It ran editorials detailing all the connections and shared sympathies between Wilhelm and the Vatican and claimed that if Germany was victorious Rome would join it in an alliance that would dominate the world.$^{58}$ Connecting the Kaiser to other contemporary bugaboos, an editorial in the same periodical managed to link German academia, paganism, and "Mohammedanism" together as animating influences on the German Emperor's bloodlust. Despite all the ways he could be associated with anti-Christian ideologies and forces historically perceived as demonic, The King's Business's editorial board still explicitly stated that they did

\footnotetext{
57 James Gray, "War, a Fulfillment of Prophecy," The Christian Evangel, October 31, 1914, 1.

58 Unknown, "Rome's Attitude," The King's Business, October 1917, 873-874; Unknown, "The Pope and the Kaiser," The King's Business, January 1918, 5-7; Gray, "War, a Fulfillment of Prophecy," 1.
} 
not think he was the Antichrist. ${ }^{59}$ The flamboyant, populist, and jingoistic crusader Billy Sunday was much less reticent, claiming Wilhelm had more in common with the Antichrist than other world leaders and G.R. Eads thought he might well be the "little horn" referenced in Daniel. ${ }^{60}$

The defeat of the Central Powers ended any remaining speculation regarding the Kaiser but in the immediate wake of the Great War some dispensationalists focused their attention on the nascent League of Nations. The ambiguity of the Biblical references to the Antichrist meant that the concept could be applied to an ideology, an institution, or a specific person and sometimes a combination of these entities. As an organization that purported to end war dispensationalists were sure the League was doomed to fail and at best was a waste of time. Many saw it in a more ominous light that was either unintentionally making things easier for the Antichrist or would actually be the vehicle for the Antichrist's rise to power. Dispensationalist preachers and fundamentalist magazines were not hesitant to weigh in on the validity of the organization.

There were a variety of approaches and most commentators at least alluded to the eschatological significance of the League of Nations but some commentators with impeccable dispensationalist credentials spent more time on concerns regarding the prudence of establishing this organization. James Gray, who The King's Business credited with representing "the position of Bible Institutes in general," opined that it was "a political more than a religious question," while others saw it in more religious terms but limited their analysis to social and Biblical considerations that were not strictly eschatological. ${ }^{61}$ In 1918, R.A. Torrey editorialized in The King's Business that given what the Bible teaches and what is known about human nature, the

\footnotetext{
59 Unknown, "The Prostitution of German Scholarship," The King's Business, April 1918, 279-280. Unknown, "Will There Be Universal and Lasting Peace?," The King's Business, January 1918, 3.

${ }^{60}$ Sutton, American Apocalypse, 69.

${ }^{61}$ Gray is cited in "The League of Nations," The King's Business, September 1919, 815.
} 
League would fail. The return of Jesus Christ was the only solution for world peace. He did mention in passing that an organization like the League of Nations would appear at the end of this age, but it was not accompanied by a warning that this particular version was a threat. Six months later in the same magazine, A.C. Dixon expressed concern that if the organization did not submit its authority to God it would be in danger of becoming "the nucleus of the Kingdom of Antichrist." Nevertheless, most of his article focused on the importance of righteousness and for him the biggest threat to the success of the League was the possibility that it would be infiltrated by "Drink Traffic," an entity that Dixon portrayed as a nefarious global power that "controls governments and owns Prime Ministers." This combination of this-worldly concerns and eschatological musings illustrates how intertwined prophetical interpretation was with whatever contemporary social issues preoccupied dispensationalists. A few months later, another editorial appeared expressing concern that the overwhelmingly Catholic makeup of the League would facilitate the increase in Catholic influence globally. ${ }^{62}$ This editorial did not make explicit eschatological claims but as we will see below, the threat of Catholicism remained a constant theme and dispensationalists would soon very confidently assert connections between world events, Catholic designs, and prophetic Biblical references.

Other commentators were more confident about the League's place in prophecy. A 1920 King's Business article claimed that whoever ultimately came to control the League would prove to be the "Politico-Beast" described in prophecy. It claimed that the Kaiser and Woodrow Wilson each wrongly thought they were the "Superman" that would rule the world and

\footnotetext{
62 Respectively, R.A. Torrey, “Can a League of Nations Work?,” The King's Business, November 2018, 932-933; A.C. Dixon, "The League of Nations," The King's Business, May 2019, 402-405; W.H.P., "Will Rome Again Dominate the World?," The King's Business, September 1919, 799-800.
} 
associated the League with "Internationalism" and "certain socialistic, communistic, Bolshevistic and nihilistic circles." $" 63$

A variety of circumstances meant that the interwar period was rife with potential individual candidates. Because of the alternative role that Russia was expected to play in endtimes scenarios (which will be explained in the next chapter), Lenin was not usually pegged as the Antichrist. Despite his inconvenient geography, his many other promising characteristics meant that in the early 1920s he was sometimes associated with the Antichrist's coming. An odd 1922 King's Business article organized around the significance of the color red claimed that "everything connected with the Antichrist is red" and that "Lenine [sic] is simply the awful shadow of the great Red king that is surely coming to reign over a great Red world."64 D.M. Panton, a British dispensationalist that was extensively quoted and sometimes published in American dispensationalist magazines, seemed to think that an antichrist out of Russia was possible, although someone "with the blood of the Caesars," and it is unclear if he meant Lenin or some other unnamed Bolshevik with a possible racial connection to Rome. ${ }^{65}$ We will see that Mussolini was the earliest and most long-lasting person of interest during these years but Stalin, Hitler and even Roosevelt were occasionally mentioned. ${ }^{66}$ Even though the Catholic Church usually played a subsidiary but still important role to the Antichrist during this period, it never completely lacked backers, as both the Pope and the head of the Jesuits were the objects of suspicion. $^{67}$

\footnotetext{
63 French E. Oliver, "The League of Nations and Prophecy's Program," The King's Business, October $1920,927$.

${ }^{64}$ Chas. J. Waehlte, "The Red Terror," The King's Business, September 1922, 908.

65 D.M Panton, “An Incomparable Phenomenon," The King's Business, September 1922, 929.

${ }^{66}$ See Matthew Avery Sutton, "Was FDR the Antichrist? The Birth of Fundamentalist Antiliberalism in a Global Age," Journal of American History 98, no. 4 (March 2012): 1052-1074.

${ }^{67}$ Regarding the Jesuits and the Antichrist see Nathan Cohen Beskin, "The Mark of the Beast," Pentecostal Evangel, July 4, 1931, 1, 8-9.
} 
After World War II the proliferation of international governing bodies generated an interest among dispensationalists similar to how the previous generation viewed the League of Nations, as the vehicle for the emergence of the Antichrist, who would become the head of those organizations. Even before the war was over, the preliminary planning for these institutions caused consternation for the prophetically-minded. The Pentecostal Evangel thought that although the term "United Nations" had a "happy ring" to those ignorant of scripture, "in view of prophetic scriptures" it had "an ominous ring about it." The author thought that it could well bring about "a coming Nebuchadnezzar, a possible anti-Christ." ${ }^{68}$ After the war, prominent dispensationalists like Arno C. Gaebelein and Harry A. Ironside saw not only the United Nations, but the North Atlantic Treaty Organization and a coming European political confederation as organizations that would reestablish the Antichrist's empire. ${ }^{69}$ This suspicion of supranational bodies continued. In the 1970s Hal Lindsey, easily the most successful popularizer of dispensationalist eschatology, argued that the ten nation European Common Market would morph into the empire headed by the Antichrist and that the Trilateral Commission was unwittingly clearing the path for the beast's one-world government. ${ }^{70}$ Even though the European Common Market expanded beyond ten nations, Lindsey continued to identify the organization now called the European Union as a harbinger of the Antichrist, a view shared by the less numerous European dispensationalist communities in places like the United Kingdom, the Netherlands, and Scandinavia. ${ }^{71}$ Given Lindsey's vast readership and influence this has been the most common viewpoint in the United States over the last few decades,

\footnotetext{
68 Unknown, The Passing and the Permanent, Pentecostal Evangel, February 19. 1944, 16.

${ }^{69}$ Wilson, Armageddon Now, 157.

${ }^{70}$ Weber, Living in the Shadow, 213, 220.

${ }^{71}$ See Brent F. Nelson and James L. Guth, "European Union or Kingdom of the Antichrist? Protestant Apocalyptic Narratives and European Unity," National Identities 19 no. 2 (June 2017): 251-267. Nelson and Guth link these dispensationalist viewpoints to Eurosceptic political movements.
} 
although individual dispensationalist authors have claimed any number of shadowy and not so shadowy organizations and figures would play a role, including the "New Age" movement, the cashless economic infrastructure (the "666 system”), the Council for Foreign Relations, any heretical or non-Christian religion (including Islam), and even members of the Evangelical Left. $^{72}$

While dispensationalists focused on global institutions did not always have a particular person in mind (yet), for many dispensationalists there were usually individuals who due to some combination of perceived threat, otherness, and possession of characteristics that fit eschatological expectations, appeared to be the "Man of Sin." Saddam Hussein's belligerence combined with his leadership of the country where ancient Babylon was situated made him an ideal candidate. Babylon is mentioned in Revelation but was normally interpreted symbolically by dispensationalists. Between the Gulf War and Desert Storm many dispensationalists were able to plausibly read those passages more literally than usual. There was a short-lived proliferation of prophetic literature during this time period, some of it claiming that Hussein was in the process of rebuilding Babylon. Hussein watchers were not limited to individuals working outside evangelical institutions, as authors included Moody Bible Institute Provost Charles Dyer, and Tim Lahaye wrote the forward for a book on the topic. ${ }^{73}$ An exhaustive list of individuals who have been identified as candidates in the last half-century would be impossible to compile given the entrepreneurial and non-institution nature of prophecy prognostication ushered in by Lindsey but prominent examples include Nikita Khrushchev, Henry Kissinger, Pope Paul VI,

\footnotetext{
72 Patterson, "Changing Images of the Beast," 451-452; Nilay Saiya, "Onward Christian Soldiers: American Dispensationalists, George W. Bush and the Middle East," Holy Land Studies 11 no. 2 (2012): 186-187.

${ }^{73}$ Charles H. Dyer, The Rise of Babylon: Sign of the End Times, (Chicago: Moody Publishers, 2003.); Joseph Chambers, A Palace for the Antichrist: Saddam Hussein's Drive to Rebuild Babylon and Its Place in Biblical Prophecy, (Green Forest, AR: New Leaf, 1996.)
} 
Ayatollah Khomeini, Anwar Sadat, Yassar Arafat, Mikhail Gorbachev, King Juan Carlos, Pope

John Paul II, Mu'ammar Gadhafi, with more recent speculation about Barack Obama, Vladimir Putin, both Clintons, and Donald Trump. ${ }^{74}$

Like current prophecy speculators, interwar period dispensationalists also lacked a central authority and had something of do-it-yourself spirit, but the larger role of Bible colleges and well-known preachers in mediating the content seemed to ensure a bit more conformity regarding the boundaries of speculation than what has transpired since the emergence of million selling laymen like Lindsay and the internet. While there was not a consensus during the interwar period and interesting variations can be identified, Mussolini was not only the figure most commonly linked to the coming Antichrist but really the only one who many writers thought actually could be him.

Interwar premillennial dispensationalists knew their Bible well enough to understand that no one could know for sure who the Antichrist would be until the rapture and the onset of the times of tribulation. A few of them, like Arno Gaebelein and J.C. O'Hair actually applied dispensationalist assumptions consistently enough to avoid speculating about the Antichrist. ${ }^{75}$ But the vast majority of them took the biblical exhortation "when these things begin to come to pass, then look up, and lift up your heads" as justification to make educated guesses, as long as their speculations were accompanied by the requisite qualifications. ${ }^{76}$ Articles on Mussolini were almost always accompanied by at least some hint of connection to the Antichrist and often included discussion of ways in which he fit the description. There was a range of

\footnotetext{
${ }^{74}$ Fuller, Naming the Antichrist, 147, 157, 159-160.

${ }^{75}$ Gaebelein called naming the Antichrist "fanatical, erratic and unscriptural" in Gaebelein, Hope of the Ages, 177; See O'Hair, "Mussolini-Ethiopia-And Us" for a critique of trying to name the Antichrist that uses dispensationalist logic.

${ }^{76}$ Luke 21:28 (KJV). For an example that uses this rationale to defend an interest in prophecy see Louis S. Bauman, There Shall Be Signs, King's Business, March 1931, 101.
} 
epistemological humility (or lack of it) in the articles. Some stopped just short of deeming him the Antichrist and emphasized the high probability that he would be. Most were less confident but would point out facts that were "interesting" or "significant" in light of prophecy. A few were convinced that they could identify something that disqualified him. What was shared by boosters and doubters of Mussolini's Antichrist credentials alike was the notion that he was in some way a precursor for the Antichrist, either by playing a part in setting the conditions necessary for his emergence or as "a foreshadowing at least of the coming super-man."”7

The idea that ideologies and social conditions could be identified with the imminent arrival of the Antichrist was present among dispensationalists decades before Mussolini came to power. In 1878 William E. Blackstone first published Jesus is Coming, which set the template for dispensationalist best-sellers. It sold millions of copies and still is in print. In a revised 1908 edition Blackstone suggested that the "atheistic and lawless trio of socialism, nihilism and anarchy" may be "the immediate precursors of antichrist." "78 Dispensationalists of the interwar era applied this notion of a precursor to the individual, especially Mussolini. He was described as "almost the immediate predecessor of the Antichrist," as "a remarkable understudy" of the Antichrist and as likely to "have a prominent part in setting the stage for the coming world dictator." One author identified him as the Antichrist's equivalent of John the Baptist, "preparing the way." one author's discussion of the nearness of the Antichrist he stated, "The World's Mussolini will

\footnotetext{
77 Oswald J. Smith, “Is Antichrist at Hand," Pentecostal Evangel, October 30, 1926, 3.

78 William E. Blackstone, Jesus is Coming. (1908; Old Tappan, NJ: Fleming H. Revell, 1932), 112.

${ }^{79}$ Respectively, Thomas M. Chalmers, "The Present Situation in World Jewry," King's Business, June 1934, 216; W. Percy Hicks, "Is Mussolini Fulfilling Prophecy," Pentecostal Evangel, April 17, 1926, 7; W.D. Herrstrom, "A Borrowed Body," King's Business, October 1936, 376; Nathan Cohen Beskin, "The Mark of the Beast," Pentecostal Evangel, July 4, 1931, 8.
} 
come." Even if Mussolini did not end up being the Antichrist "his spirit is the spirit of the last great antagonist of Israel."${ }^{\circledR 0}$

So why was Mussolini the most popular candidate during this period? Why was he unintentionally able to sustain such an intense interest for over 15 years among a group of people that have seen characteristics of the Antichrist in such a wide variety of sources? Part of the answer does have to do with an unusual congruence between his situation, personal characteristics and the eschatological framework that preceded his emergence. But it also is partly explained by the way that his characteristics tied into the most pressing issues on the minds of interwar fundamentalists. It makes sense to start with the most prominent eschatological consideration. We have seen dispensationalism is flexible enough that a case could be made for almost anyone to be the Antichrist. That being said, the more straightforward the application of previous eschatological assumptions to the contemporary situation the more persuasive and influential the arguments will be. Mussolini's position as the leader of Rome meant dispensationalists could speculate with minimal intellectual gymnastics regarding his political status and geographical position. The revival of Rome is the place to start.

\footnotetext{
${ }^{80}$ Louis S. Bauman, Present-Day Fulfillment of Prophecy, King's Business, June 1933, 182; Louis S. Bauman, "The Marks of the Antichrist: Will Mussolini Fill the Bill," King's Business, February 1926, 106.
} 


\section{CHAPTER II: THE RETURN OF ROME}

Mussolini possessed many characteristics that made dispensationalists wonder about his role in the end times. One thing that distinguished Mussolini from other candidates like Stalin and Hitler was the way that geography interacted with prophecy. He was the leader of the modern nation-state that shared a capital with the ancient Roman Empire. For a variety of theological and historical reasons, dispensationalists attached a great deal of importance to the role that a renewed Roman Empire would play in the eschaton. Even for dispensationalists who thought Mussolini was only a forerunner to the Antichrist, Rome was significant in their interpretations of prophetic Biblical passages. The most common interpretation during this time period was that key verses in the book of Daniel and Revelation referred to a Roman Empire that would be reconstituted during the end times. Rome is not mentioned in these prophetic books and although dispensationalists stressed their "literal" reading of the scripture, how strictly they maintained their literalism varied.

In Daniel chapter 7, the author records a terrifying vision of a series of four beasts: a winged lion, a bear-like creature, a four-headed winged leopard, and a powerful beast with iron teeth and ten horns. A "little horn" then arose out of the fourth beast, with human eyes and a boasting mouth. An interpretation of the vision follows, as Daniel is told by a heavenly being that the beasts represent kingdoms and the fourth beast represents a kingdom different from all

others that would "devour the whole earth, and shall tread it down, and break it in pieces." 81 The little horn was a king that would come out of that kingdom and "speak great words against the Most High" and oppress his followers. ${ }^{82}$ The book of Revelation also details terrifying beasts, ten kings, and oppressive kingdoms to come, so dispensationalists (and other apocalyptic minded

\footnotetext{
${ }^{81}$ Daniel 7:23 KJV

${ }^{82}$ Dan. 7:27 KJV
} 
Christians throughout history) read Daniel alongside the book of Revelation, understanding them as overlapping accounts of the same events from different vantage points. In Revelation, chapters 17 and 18 portray Babylon as the political epicenter of these events but describe it as a city with seven hills. Interpreters from various groups and time periods have differed regarding the identity of the city John described. As we saw above, some have taken "Babylon" literally, especially if international events were conducive to that interpretation, and W.E. Blackstone thought that Mesopotamian city would become a global commercial center and "Satan's earthly capitol." ${ }^{83}$ Others concluded that this is code for Rome, citing the topography and Rome's role in persecuting Christians at the time this book was written.

The Roman interpretation was the overwhelming consensus for dispensationalists during the interwar period, although there were always a few dispensationalists who even then took the Babylonian identity literally. Dispensationalists saw these descriptions as prophecies of what would take place as the current dispensation came to an end with "the tribulation." Their interpretation of these books led them to expect that at the beginning of the seven-year tribulation period, Rome's leader, who dispensationalists viewed as the Antichrist, would make a covenant with Israel. Three and one-half years into the tribulation the Roman leader would change course, ending the revived temple worship of the Jews and beginning a terrible persecution that would culminate in the battle of Armageddon and Christ's return at the end of the seven years. ${ }^{84}$

All of this meant that the prospect of a restored Roman Empire was thrilling to the dispensationalists. Many dispensationalists expected that the territory of Italy's new empire

\footnotetext{
${ }^{83}$ Blackstone, Jesus is Coming, 112.

${ }^{84}$ See Louis T. Talbot, The Coming World Dictator, (Glendale, CA: Church Press, n.d.), 10-16. For a dissenting view regarding Babylon's identity see James Dunbar, "Will Babylon be Rebuilt," King's Business, October 1924, 619-620.
} 
would correspond closely to the ancient Roman one. Already in 1915 dispensationalists were predicting that the Great War would ultimately join together the nations of the old empire. After the war, but before Mussolini took power, dispensationalists were pointing out ways that the post-war territorial changes were making the reestablishment of the original Roman Empire's boundaries more plausible. ${ }^{85}$

Mussolini was not only the leader of Italy but from the beginning made clear his plans to establish an empire. Early Fascism was a diverse movement and scholars have struggled to agree on how to concisely define it but there is no doubt that a major feature was its expansive nationalism. ${ }^{86}$ Many early Italian Fascists were veterans of the Great War who were resentful of what they saw as unfair treatment of Italy's postwar claims. As the "least of the Great Powers" Italy did not have the leverage to enlarge their territory commensurate with the sacrifice these disillusioned veterans made. Mussolini was able to effectively harness these resentments in order to increase his influence, using constant imperial rhetoric. Weeks before the famous "March on Rome" in 1922 that precipitated his ascension to Prime Minister, Mussolini was making aggressive declarations about foreign policy and advocating the expulsion of foreigners from the Mediterranean, calling it "our lake." ${ }^{87}$ By 1923 he was describing Italy's "necessary expansion in the world." ${ }^{88}$

Although Mussolini focused more on consolidating his domestic position throughout the 1920s and Italy could not really claim to have reestablished an empire until 1935, sporadic smallscale military actions and regular bellicose pronouncements were more than enough to maintain

\footnotetext{
${ }^{85}$ See E.T Slaybaugh, "Effect of the Universal War," The Bridegroom's Messenger, May 1915, 4; Frodsham, "The Return of the Lord," 7.

${ }^{86}$ I will be capitalizing "Fascism" and "Fascist" when referring specifically to the Italian political movement. When referring to fascism as a more general and transnational political ideology I will be using the lower-case.

${ }^{87}$ Robert Mallett, Mussolini in Ethiopia, 1919-1935. (New York: Cambridge University Press, 2015$), 11$.

${ }^{88}$ Denis Mack Smith, Mussolini as a Military Leader. (Reading, UK: University of Reading, 1974), 3.
} 
dispensationalists' attention. The first actual shooting was very modest and ultimately resulted in no strategic benefit. In 1923 an Italian general was murdered in Greece, and Italy responded by bombarding and securing the Greek island of Corfu. The Navy was told a month ahead of time to prepare for an invasion, so Mussolini was obviously looking for a pretext to start working towards his promised domination of the Mediterranean. ${ }^{89}$ International pressure forced him to give up this small victory in exchange for reparations from Greece but maybe more importantly for Mussolini, his violent response enhanced his domestic reputation. It also impressed dispensationalists, including Aimee Semple McPherson who a few years later claimed that by giving Greece "a spanking" he "made the League of Nations the laughing stock of the world."

For the next decade much of Italy's military efforts were directed in exerting control in Libya, one of the few colonies the Fascists inherited from the Liberal government, along with Somalia, Eritrea, and the Dodecanese Islands. They managed to pacify the Bedouin rebels by 1932 but not without a great deal of trouble and the use of concentration camps. Although Mussolini claimed that Italy's prestige had been enhanced by the campaign, the fact that even with severe and treacherous methods it took a European power several years to defeat poorly armed tribesmen that probably never numbered more than one thousand at any given time did not impress the few members of the international community that were paying attention. Italy did successfully intervene in nearby Albania to bring Ahmed Zog to power, who agreed by treaty in 1926 to make Albania an Italian satellite. ${ }^{91}$ Despite the limited actual expansion during this time period, the rhetoric continued unabated and dispensationalists took Mussolini's pronouncements seriously.

\footnotetext{
89 Denis Mack Smith, Mussolini's Roman Empire. (New York: Longman, 1976), 5.

${ }_{90}$ Aimee Semple McPherson, "'Sunset Hour' Bespeaks Need of Keeping Ever Unceasing Vigil for Second Coming," Foursquare Crusader, November 7, 1927, 4.

${ }^{91}$ Smith, Mussolini's Roman Empire, 36-41, 20-21. Albania would be annexed by Italy in 1939.
} 
Already in 1924, fundamentalist magazines were publishing articles on Mussolini’s plans for empire and tying them explicitly to prophetic fulfillment. A Pentecostal Evangel article said that though one could not be sure that Mussolini was the Antichrist, he was "in the right place and has the right power. ${ }^{\prime 92}$ By 1925 Mussolini had weathered the controversy over the murder of a socialist parliamentarian by a Fascist squad, purged the cabinet of liberals, and solidified his dictatorship. In a less precarious position domestically, he made frequent pronouncements regarding his foreign policy aims. American newspapers covered him closely and dispensationalists avidly consumed and then cited the articles. For example, C. E. Robinson, the associate editor of The Pentecostal Evangel, mentioned a December 1925 Chicago Tribune article as support for his claim that Mussolini's plans to "re-establish the Roman Empire on its original lines" were "rapidly ripening." ${ }^{\prime 93}$ In January 1926, The King's Business first published an article by Louis Bauman, reproducing his address to the Southern California Premillennial Association. Bauman heavily emphasized the significance of a revived Roman Empire, which would remain a consistent feature of not only his articles but most of the dispensationalist articles on Mussolini published in the next 15 years. ${ }^{94}$ Bauman became a regular contributor to The King's Business and other major fundamentalist periodicals and was probably the most consistent advocate for Mussolini as the Antichrist.

Bauman's first article in The King's Business illustrates the beginning of a transition that took place in dispensationalist thinking during the 1920s. As we saw above, after World War I the League of Nations loomed large in their interpretations. An international body that bound nations together seemed like a development that would pave the way for the kind of one-world

\footnotetext{
92 John Goben, "The Revival of the Roman Empire," The Pentecostal Evangel, November 15, 1924, 2.

${ }^{93}$ C. E. Robinson, "When to Pray and How: Chapter Nine of Daniel," The Pentecostal Evangel, March 6, 1926, 8.

${ }^{94}$ Louis Bauman, "Is the Antichrist at Hand? What of Mussolini?" The King's Business, January 1926, 15-16, 42.
} 
government that they expected when the Antichrist would come. Under the heading "A Sure Word of Prophecy" Bauman stated: "We presume you know that the Antichrist will become the head of the great League of Nations, whose armies will at last gather against Jerusalem for battle." 95 This conflation between the revived Roman Empire and the League of Nations would disappear from Bauman's and other dispensationalist articles by the beginning of the next decade. In 1930 H.A. Ironsides rejected the idea that the League of Nations was the political union that would defy God but did think it "would soon give place to another." Bauman spoke of various "leagues" being formed by frightened nations that would set the political stage for the final confrontation described in prophecy but the League of Nations in particular was never mentioned. ${ }^{97}$ Usually when it was mentioned in the 1930 s, the League of Nations was portrayed as a well-intentioned but hopelessly naïve and powerless institution while the Beast's confederation of nations would be portrayed independent from it, forging an alternative path to global domination. By the time Mussolini invaded Ethiopia in 1935, Bauman was dismissing the League of Nations as a "demoralized old mollycoddle" with "the shaking palsy." 98

English suffragette turned Southern California dispensationalist Christabel Pankhurst was often cited in American fundamentalist periodicals and despite patriarchal positions regarding preaching and domestic roles, many prominent male fundamentalists seemed to respect her contributions. ${ }^{99}$ Pankhurst strongly emphasized the prophetic significance of a restored Roman

\footnotetext{
${ }^{95}$ Bauman, "Antichrist at Hand?," 15.

${ }^{96}$ H.A. Ironsides, "Looking Backward Over a Third of a Century of Prophetic Fulfillment," The King's Business, March 1930, 123.

${ }^{97}$ Louis Bauman, Present Day Fulfillment of Prophecy, The King's Business, January 1932, 6.

${ }^{98}$ Louis S. Bauman, "Socialism, Communism, Fascism, The Fascist Hosts are Marching: To Ethiopia or Armageddon?," King's Business, August 1935, 292.

99 John R. Rice vividly demonstrated the dispensationalist mindset on gender roles in the title of his Bobbed Hair, Bossy Wives and Women Preachers. (Murfreesboro, TN: Sword of the Lord, 1941); Arno Gaebelein, who spurned
} 
Empire throughout the 1920s. In 1924 she thought the League of Nations would have some role in "the promotion of the reunion of the Roman nations" but thought the actual revived empire would emerge independent from the League. ${ }^{100}$ Pankhurst had more of an emphasis on the role of ethno-racial affinities than most dispensationalists and by 1929 was talking about an emerging "Latin bloc" that would form the basis for the $20^{\text {th }}$ century version of the ancient empire. ${ }^{101}$

While interest in the League waned, speculation regarding how international events were leading to the reestablishment of the Roman Empire was ubiquitous in dispensationalist literature right up to World War II.

While some dispensationalists were speculating about the ways that the Great War paved the way for the Empire's resurgence before Mussolini came on the scene, his emergence caused more of them to find significance in how the war affected political boundaries. The Pentecostal Evangel thought it was significant that "Roman" nations (France, Belgium, and Britain) had fought "German tribes" and that Italy reversed course and sided with the Roman group. Russia left the war and therefore left the Roman group, while the breakup of the Austro-Hungarian Empire freed up former Roman areas, and Ireland (never part of the Roman Empire) became independent from Great Britain. ${ }^{102}$ Pankhurst believed Italy switched sides because to enter the war on the side of Germany and Austria "would have been a contradiction of history past and prophetic." Abandoning the Central Powers facilitated "its return to its original geographical and racial basis." She also noted that Russia's exit from the Entente meant that almost all of the alliance was Roman and almost everything Roman was in the alliance. Even the United States

\footnotetext{
Aimee Semple McPherson and was among the most orthodox of dispensationalists in his application of dispensationalism to church affiliation, nevertheless called Pankhurst "an interesting lecturer and writer on prophetic truths." Gaebelein, Half a Century, 209.

${ }^{100}$ Christabel Pankhurst, Pressing Problems of the Closing Age. (London: Morgan and Scott, 1924$), 103$.

${ }^{101}$ Christabel Pankhurst, Seeing the Future. (New York: Harper and Brothers, 1929), 309-314.

102 Unknown, "The Resurrection of the Roman Empire," Pentecostal Evangel, October 9, 1926, 1-2.
} 
was "not unconnected to Rome by reason of her national descent and the racial character of the main elements of her population."103

In the mid-1920s Fascists were starting to argue in print that Fascism was innately imperialist and that an empire must be acquired for reasons of prestige or even as an end in and of itself, irrespective of economic rationality. By 1927 Mussolini was claiming, without any empirically verifiable reason to do so, that Italy's military was ready for war and Fascist rhetoric made it sound as if the success of their imperial aims were guaranteed. ${ }^{104}$

Dispensationalists saw this as extremely significant and dispensationalist magazines closely kept watch for any signs of Italy's growing assertiveness and plans for expansion. Increasing nationalism, improved economic conditions, and growing military capabilities of Italy were consistently reported. Sometimes reports of those developments were accompanied by extensive explanations of how they fit into prophecy, sometimes they were accompanied by briefer statements regarding what "great interest" these events were to "students of prophecy," but sometimes they were just reported in a straightforward fashion without commentary. ${ }^{105}$ Given the other content of the magazines it can only be concluded that when commentary was absent the prophetic import was so obvious they did not need to spell out its relevance. Even in the absence of much actual expansion dispensationalists seemed to take Mussolini's pronouncements about not only his aims but his assured success at face value. While reporting Mussolini’s “[b]ombastic utterances, backed up by tremendous ability to perform” Ironsides claimed that "[h]is grandiose plans move on to fulfillment in spite of all opposition."

\footnotetext{
103 Pankhurst, Pressing Problems, 99-103.

104 Smith, Mussolini's Roman Empire, 32, 16.

105 For examples of the respective approaches see Bauman, "Socialism, Communism, Fascism," 292-294; Paul Rood, Around the King's Table, King's Business, September 1936, 332; Unknown, "Mussolini Forges Ahead," Pentecostal Evangel, May 15, 1926, 9.

106 Ironsides, "Looking Backward," 123.
} 
Italy's attempt to solidify the control of its relatively meager colonial possessions it inherited from previous liberal governments attracted some notice from dispensationalists. Pankhurst interpreted Fascist Italy's attempts to strengthen their grip in North Africa as "a return to Roman Africa." $" 107$

\section{The Empire Reestablished}

Mussolini was a master of manipulating impressions but at some point he had to deliver on his ambitious intentions, so in the early 1930s Mussolini began to make more concrete moves to establish his empire. Robert Paxton argues that to maintain their legitimacy fascist regimes needed to "to produce an impression of driving momentum," a constant pressure that ultimately forced Mussolini to more than merely rhetorical imperialism. ${ }^{108}$ He needed a significant victory, preferably at low cost with a low risk of failure. As the last non-colonized part of Africa, Ethiopia fit the bill. A successful invasion of Ethiopia would also avenge the 1896 defeat at the Battle of Adwa, where Emperor Menelik II and his Ethiopian troops repelled Italy, a source of embarrassment for nationalists. This would show that Mussolini could do what a liberalizing Italy could not.

Italy had its eyes on Ethiopia at least since the mid-1920s when the military produced contingency plans for its occupation. Italy and Ethiopia had signed a treaty of friendship in 1928, but Ethiopian Emperor Haile Selassie sought to maintain his nation's autonomy while Mussolini saw the treaty as a step towards de facto annexation. By 1929 Italy had begun to exploit the ambiguous borders between Ethiopia and both Italian-occupied Somaliland and Eritrea. Mussolini purposely delayed addressing Selassie's entreaties to define those boundaries.

\footnotetext{
107 Pankhurst, Seeing the Future, 322.

108 Robert O. Paxton, The Anatomy of Fascism. (New York: Alfred A. Knopf, 2004), 148, 164-165.
} 
This confusion would make it easier to blame Ethiopia for aggression if a pretext for invasion was needed. ${ }^{109}$

That pretext came in November,1934. Italy had a fortress within the disputed boundaries at the oasis of Wal Wal and Ethiopian troops confronted the Somalian soldiers there that were under Italian command. A standoff led to the outbreak of fighting by December 5. Each side blamed the other but whoever was at fault, Mussolini had his justification to escalate the situation. ${ }^{110}$ The invasion of Ethiopia finally came in October 1935. Despite poor planning, logistical logjams, and international pressure, Italy could declare victory by May of 1936 and announced complete pacification by that December. Even with superior technology and the backing of an industrialized economy, Italy's victory was not a smooth one and was helped along by extensive use of poison gas. Furthermore, pockets of resistance continued and some of the worst Italian atrocities occurred after the so-called pacification. For their trouble, Italians were to rule a hostile population for five years, derive little if any security benefit, and despite claims to the contrary, accrue a major net economic loss. That being said, an argument can be made that was a rousing success for Mussolini, at least in the short term. Mussolini's incredibly prolific biographer Renzo De Felice called the victory his "political masterpiece" due to how popular the war was domestically, which after all may have been the most important thing. Mussolini was now able to plausibly claim that his Fascist rule had stood up to the international community and reestablished the Roman Empire. Nevertheless, the whole incident permanently undermined the arguments of the dwindling group of apologists for Mussolini in the democratic world. ${ }^{111}$

\footnotetext{
${ }^{109}$ Smith, Mussolini's Roman Empire, 16, 59-60.

${ }^{110}$ Mallett, Mussolini in Ethiopia, 119-120.

${ }^{111}$ Smith, Mussolini's Roman Empire, 70-81; De Felice is quoted in J.B. Bosworth, The Italian Dictatorship (New York: Arnold, 1998), 76.
} 
America's response to the war was mostly censorious. While the American Left and Center opposed both Fascism and the invasion, American big business mostly opposed the instability that the conflict engendered and focused their criticism on Mussolini's judgement more than on the legitimacy of Fascism. Even the normally sympathetic Chicago Tribune became critical when attempts at economic penetration (which it supported) turned to overt military action. This opposition had tangible consequences for Italy as American credit became nonexistent. Italian Americans were the lone group that still evinced strong support for Mussolini, although American Catholics were somewhat divided. ${ }^{112}$

The dispensationalist interest in Mussolini that began shortly after his ascent to power never waned during the interwar period, but an unusual profusion of articles came after his invasion of Ethiopia. Dispensationalists had been expecting the revived empire to correspond exactly with the boundaries of the ancient one but inconveniently Ethiopia was never part of it in the past and possibly was referenced in Ezekiel as "Cush," who would fight in a "Northern Confederacy" against the Antichrist farther along in the prophetic timeline. Nevertheless, many saw this as the beginning of the Roman Empire's actual reestablishment. Some saw it as a foothold in the region that would allow for the future acquisition of formerly Roman territory, including Palestine. W.D. Herrstrom saw the events in Italy and Ethiopia as a "resurrection miracle." He thought that Ethiopia would serve as a convenient military base for Italy when the time would come to move on the Suez Canal and also saw road-building projects in Libya as part of this effort. ${ }^{113}$ Furthermore some dispensationalists were able to find ways that this conquest could fit into the prophecy. Ethiopia is mentioned in the Old Testament several times, although

\footnotetext{
112 Diggins, Mussolini and Fascism, 295-306.

113 See John R. Rice, "Mussolini Restores the Roman Empire," Sword of the Lord, May 22, 1936, 1; Harry J. Steil, "Ethiopia versus Italy," Pentecostal Evangel, October 9, 1935, 18; W.D. Herrstrom, "The Resurrection of an Empire," King's Business, September 1937, 336, 358.
} 
the references had rarely been significant for white fundamentalists before this time period. On the other hand, some African American theologians used verses like Psalm 68:31 to argue that Africans would rule with Jesus at the end of the age and the Abyssinian church would play a role in bringing about the Millennium. ${ }^{114}$

Unsurprisingly white fundamentalists did not draw the same conclusions, but they could turn to the book of Daniel for guidance. In chapter 11 a "willful king" is described that many dispensationalists equated with the "little horn" mentioned earlier in chapter 7 that they interpreted as the future leader of the revived Roman Empire. In Daniel 11:43 it says that this king will control "the treasures of gold and of silver, and over all the precious things of Egypt; and the Libyans and Ethiopians shall be at his steps." Bauman thought this passage revealed the Antichrist's "line of march to the battlefields of Armageddon," that is he would conquer Libya, Ethiopia, and Egypt before meeting the great Northern Army that Bauman believed to be the Soviet Union in a final great battle in Palestine. Prophetic and anti-evolutionary author Arthur I. Brown pointed out that Mussolini had expressed an interest in all three places mentioned in that verse and already possessed two of them. ${ }^{115}$ Harry Steil argued that Mussolini's motives were even predicted in this verse. He gave a long explanation of Italy's financial woes, claiming that Mussolini was interested in Ethiopia's supposed gold reserves. ${ }^{116}$

Afterwards, Bauman saw the successful invasion as a vindication of his predictions he had been making over the years. He reprinted part of a 1927 sermon in which he noted that

\footnotetext{
${ }^{114}$ Sutton, American Apocalypse, 63-64, 217. In the KJV the verse reads: "Princes shall come out of Egypt, Ethiopia shall soon stretch out her hands unto God." One white Pentecostal, Harry Steil, thought it was possible that the verse was fulfilled when Emperor Hailee Selassie called on his nation to pray for deliverance from the coming attack. Steil, "Ethiopia versus Italy," 1.

${ }^{115}$ Bauman, "Socialism, Communism, Fascism," 292-294. Arthur I. Brown, The Eleventh Hour. (Findlay, OH: Fundamental Truth, 1940), 55-56.

${ }^{116}$ Harry Steil, "Ethiopia versus Italy," 1, 17-18.
} 
people had "laughed the idea to scorn" when he first showed interest in Mussolini as the possible Antichrist but less "were laughing now." After that quote he stated "now, nine years later, as we write, fewer still are laughing that possibility to scorn." Bauman made much of Mussolini's May 9, 1936 public speech where "the new triumphant Caesar shouted," among other things: "After fifteen centuries, salute the reappearance of the Empire on the fateful hills of Rome!"117

Not all dispensationalists saw the defeat of Ethiopia as powerful evidence for Mussolini as the Antichrist. But even those that expressed some of the strongest doubts that Mussolini was the Antichrist saw this conquest as a step in the direction of Armageddon. L. Sale-Harrison rejected the prophetic import of Ethiopia, expected the Antichrist to remain in the good graces of other world powers in the leadup to Armageddon, and thought it was "utterly absurd" to think that Mussolini would be the Antichrist. He said this baldly acquisitive invasion disqualified Mussolini from consideration to be the "cunning and clever diplomat" who would use guile to get the respect of the nations. Still, even for Sale-Harrison the results of Mussolini's military build-up and aggressive foreign policy would be useful in the hands of "a stronger and more cunning dictator" to come. ${ }^{118}$

Belying the claims of their detractors, dispensationalists were not exclusively preoccupied with eschatological concerns. As Matthew Sutton argues, their apocalyptic mindset could serve as a spur to service more than an excuse for inaction. ${ }^{119}$ Alongside purely prophetic articles discussing the ways that events like the invasion of Ethiopia did or did not fit into the Bible's predictions were articles addressing the practical effects it would have on mission work in the region. Missionaries were concerned that if Italy won their access to Ethiopia would be

\footnotetext{
${ }^{117}$ Bauman, "Reappearance of the Empire," 257-258.

118 L. Sale Harrison, "The Resurrection of Imperial Rome," Moody Bible Institute Monthly, June 1936, 494.

${ }^{119}$ Sutton, American Apocalypse, 5.
} 
restricted, like it was in Eritrea. ${ }^{120}$ Although they did not share the messianic expectations related to Ethiopia that some African American churches did, white fundamentalists did express an affinity for Ethiopia and Selassie in their publications. By 1923 positive assessments of Ras Tafari began to show up in dispensationalist periodicals. ${ }^{121}$ Ethiopia's connections to the early spread of Christianity, claims of Solomonic descent, and openness to Protestant mission work were part of the appeal, but the ambiguous racial identity of the ruling Amharic peoples seemed relevant as well.

In an October 1935 King's Business interview with a missionary to Ethiopia the third question asked was whether or not Ethiopians were "negroes." The missionary said "real Ethiopians" were not, tracing their lineage to the Biblical "Cush" and he claimed their "standard of intelligence is quite above that of the ordinary Negro races" with a "proud and independent spirit," a "consciousness of superiority to the Negro races that gives them a certain quality of leadership," and an ability to "learn quickly." The interviewer and this missionary were not unique in the racial identification of Selassie and his ethnic kin as important. ${ }^{122}$

Two years earlier another missionary to Ethiopia had spoken rapturously at Moody Bible Institute's Founder Week about his personal meeting with Selassie. After describing the Emperor's appreciation and pledges of support for his work, the missionary pointed out that he was not a "negro." He approvingly reported Selassie's rebuke of "Harlemites" who had congratulated him on being a colored king. Selassie said he was not "colored" but rather could trace his lineage back to Solomon. In neither the interview or the address did they make it

\footnotetext{
120 Unknown, “An Ethiopian Missionary Speaks,” Pentecostal Evangel, November 16, 1935, 5.

121 Robert H. Glover, Missionary Department, Moody Bible Institute Monthly, October 1923, 74-75.

122 Unknown, “Ethiopia Today," King's Business, October 1935, 368-369, 373-374.
} 
explicit why this was important, but it obviously was to them and they seemed to expect the reader to understand its importance without explanation. ${ }^{123}$

The King's Business interviewer did ask how far away Ethiopia was from Jerusalem, but much of the interview was preoccupied with this-worldly issues, especially the prospects for continued mission work in light of the coming Italian invasion. The missionary did mention that although Ethiopia's place in prophecy is unclear, he interpreted Daniel 11 as a prediction that it would be conquered in the future by the revived Roman Empire. If that happened it would be a sign that the end is near. Still, he called for prayer that whatever happened politically mission work would be able to continue and for wisdom for Selassie, "the most enlightened monarch ever to occupy the Ethiopian throne." 124

Dispensationalists were also keeping their eye on Mussolini's interactions with the Muslim world. Muslims have played a more prominent role in prophetic speculation since the end of the Cold War, but they have had at least a subsidiary role throughout the $20^{\text {th }}$ century, mostly due to their opposition to the reestablishment of Israel. Even in World War I some dispensationalists were concerned the Kaiser's forces would extend into North Africa and stir “up a few million Moslems," giving the world "enough 'holy war' to satisfy all the nations." The degree of emphasis placed on Muslims fluctuated with international events and the interwar period saw some interest from dispensationalists that was not completely explained by their relationship with the Jews settling in Palestine. ${ }^{125}$

Much of North Africa was also part of the original Roman Empire, so many dispensationalists anticipated a large Muslim contingent among the Antichrist's forces. In the

\footnotetext{
123 George H. Rhoad, "Meeting the King of Abyssinia," Moody Bible Institute Monthly, August 1933, 540-541.

124 "Ethiopia Today," 368-369, 373-374.

${ }^{125}$ Frank Bartleman, "The War-Separation," The Bridegroom's Messenger, January 1916, 4.
} 
aftermath of World War I, Pankhurst detected a desire by European statesman to bring the Muslim world into European colonial holdings. As the victors carved up and distributed the former Ottoman Empire she saw the resulting mandate system as a move toward a more permanent incorporation. Although the mandate system was dominated by the British and French, Pankhurst still thought "the might, the prestige, the attraction, the glamour of the Roman Empire to which, in ancient times they actually did belong" would eventually bring Muslims in voluntarily. This prediction seemed to be based on Orientalist assumptions about Muslim psychology as much as literalistic Biblical exegesis. Pankhurst claimed Muslims would be particularly susceptible to "the magnetic power of leadership" that the final Caesar would possess in abundance, given that "the Moslem believes in leadership, thrills to it, answers to it." Threads of Orientalism run through dispensationalist depictions of Muslims as they were sometimes depicted with a latent bellicosity ripe to be stirred up. ${ }^{126}$

Bauman claimed that in North Africa "vast Moslem hordes are in ferment," given they are "badly afflicted with an ancient Moslem disease—a swelling of the chest." Demonstrating his sometimes-feverish prose that made him one of dispensationalism's favorite prophetic interpreters he claimed Mussolini's interactions had "not lessened their blood pressure any. With their hot warrior blood throbbing through ever quickening pulses they mount to ride- they know not where! All is dark!" He even saw India's Muslim minority as "ready, at a given signal, to swim through seas of blood that the Crescent may float over those teeming multitudes." Thankfully Great Britain was "leaning against the gates," resisting "this Islamic flood." When the coming pandemonium breaks out Muslims would be temperamentally inclined to play a significant role. ${ }^{127}$ The Pentecostal Evangel wondered if Italy's roadbuilding in its North

\footnotetext{
${ }^{126}$ Pankhurst, The World's Unrest, 60.

${ }^{127}$ Louis S. Bauman, “This Befogged and Befuddled World," The King's Business, June 1937, 209.
} 
African colonies was related to prophecies in Daniel that the Antichrist would conquer Egypt. The possibility of a Mussolini-led Muslim army likely explains why they thought it was significant that Mussolini was described by Libya's Governor-General as the "protector of Islam." ${ }^{128}$

\section{Antichrists but not the Antichrist}

Dispensationalist geographic interpretations also served to exclude figures that might have otherwise rivaled Mussolini. Even staying consistent with dispensationalist assumptions, the final leader of the Roman Empire would not necessarily have to hail from modern-day Italy but if a leader's country had a different role in prophecy that would be more problematic.

We will see below that economic collectivization and godless ideology were predicted by dispensationalists for eschatological reasons and also were major concerns in their own right. Just looking at those two measures Stalin would seem to be a better fit than Mussolini. Stalin was sometimes mentioned as a possibility, but it was much more common for dispensationalists to rule him out because of Russia's perceived prophetic role. Ezekiel 38 describes an ill-fated invasion of Israel by a northern Army headed by a Prince Gog of Magog. Throughout Christian history different nations have been associated with this group and the Ottomans were a common suspect between the $13^{\text {th }}$ and $18^{\text {th }}$ centuries. ${ }^{129}$ That changed in the $19^{\text {th }}$ century as apocalyptic minded Christians started to associate Russia with the northern kingdom. In 1809 British writer George Stanley Faber was one of the earliest to make this connection. He saw Napoleon as the head of a restored Roman Empire that would be unsuccessfully attacked by Russia. The Antichrist, Napoleon, would only be defeated by God when he attacked a "great maritime power" that Faber thought was alluded to in prophecy. Faber was pretty confident that power

\footnotetext{
128 Unknown, "Mussolini and the Moslems," Pentecostal Evangel, June 11, 1938, 17.

129 Paul Boyer, When Time Shall Be No More (Cambridge, MA: Belknap Press, 1992), 152-153.
} 
would prove to be England, especially if its people increased their piety. ${ }^{130}$ Unsurprisingly given the international situation Faber saw Russia's intentions as benevolent but this interpretation changed as global geopolitics changed and Russia's place in prophecy evolved and filled out over the $19^{\text {th }}$ century.

Scottish preacher John Cumming established in the 1850s what would become a common dispensationalist understanding of Russia. Cumming employed very questionable linguistic arguments to identify obscure Biblical names with current nations, including the areas mentioned in Ezekiel: "Rosh," "Mesech," and "Tubal," that he associated with different areas of $19^{\text {th }}$ century Russia. This meant the prince "Gog, of the land of Magog" would represent the leader of wider Russia. Chapter 39 of Ezekiel, one of the most important chapters in the Bible outside of Revelation and Daniel for end-times prognosticators, prophesies the destruction of Gog after an attack on Israel. Cumming and later, many dispensationalists then expected that this "Northern Confederacy" would sweep down into Palestine only to be obliterated in the battle of Armageddon. ${ }^{131}$ Dispensationalists were alert to any prophetic clues that would confirm their conclusions and Bauman thought it was significant that Ezekiel 38:15 described a vast army out of the North on horseback, while Russia possessed the most horseflesh in the world. ${ }^{132}$

By the 1920's most dispensationalists continued to embrace this interpretation with the added twist that it would be the Antichrist leading the Roman Empire that would destroy Russia during its invasion of the Holy Land, although there were a minority that thought they would join

\footnotetext{
${ }^{130}$ Wilson, Armageddon Now!, 20-21. Isaiah 24:15 and Isaiah 60:9 were the verses from which Faber derived this interpretation.

131 Wilson, Armageddon Now!, 26-28.

132 Louis Bauman, Light From Biblical Prophecy as Related to the Present Crisis, $3^{\text {rd }}$ e d. (New York: Fleming H. Revell Company, n.d.), 45; Louis Bauman, God and Gog or the Coming Meet between Judah's Lion and Russia's Bear (Long Beach, CA: n.p., n.d), 17-18. Both are reprinted in Louis S. Bauman, Biblical Prophecy in an Apocalyptic Age, Selected Writings of Louis S. Bauman, ed. Joel Carpenter (New York: Garland, 1988).
} 
together. In all versions God would ultimately destroy the Antichrist and whoever else was left standing. ${ }^{133}$ This meant the leader of Russia had a major prophetic (and evil) role but it was usually seen as distinct from the Antichrist and actually in opposition to him. Therefore, dispensationalist depictions of Lenin and then Stalin were uniformly eschatologically informed and negative, but they rarely were depicted as the Antichrist. The Bridegroom's Messenger illustrated this phenomenon and some of the various ways the Antichrist concept could be employed when they claimed Lenin was "not the anti-Christ but he is an anti-Christ."134

As Adolf Hitler surpassed Mussolini as the premier dictatorial threat in Europe it might be expected that he would also pass him in the Antichrist sweepstakes. His viscous antiSemitism made for a strong candidacy but as we will see below Mussolini's more ambiguous approach to Jews actually fit dispensationalist expectations better. Like Stalin he had a few backers, but he also shared an inconvenient geography with the Russian strongman.

Hitler had the same problem that caused The King's Business to rule out Kaiser Wilhelm a couple decades earlier: Germany could be found in prophecy in a role different than the Antichrist. Cumming not only associated Magog with Russia but identified how the other members of Magog's confederacy matched up with the contemporary political landscape. Ezekiel 38:6 includes "Gomer, and all its hordes" among the peoples who would assemble under Gog for the climactic battle. Cumming identified the descendants of Gomer listed in Genesis 10:3 (including Ashekenaz, whose name is the root from which Ashkenazim was derived) as the predecessors of modern Germans. This identification persisted among dispensationalists and influenced their interpretations into the 1930s. Therefore, to many dispensationalists, however

\footnotetext{
${ }^{133}$ Wilson, Armageddon Now!, 26-28, 51. These geographic references come from Ezekiel 38:2 and Ezekiel 39:1. Gog's destruction is described in Ezekiel 38:1 to Ezekiel 39:24.

${ }^{134}$ Unknown, "The Anti-Christ," The Bridegroom's Messenger, August 1923, 4.
} 
threatening Germany seemed to be it would have a subsidiary role to Russia and suffer the same fate. ${ }^{135}$

This does not mean that those dispensationalists who ruled Hitler out ignored him. Their understanding of the prophetic picture had room for many players besides the Antichrist. Arthur Brown claimed that Hitler, Mussolini, and Stalin were the "three most Satanic personalities yet to be turned loose on civilization."136 What these world figures shared is that they were all unwittingly part of the Divine Plan, in spite of their evil intentions. Dispensationalists were concerned above all with developments relevant to Israel and Hitler was sometimes associated with Haman, the Persian vizier from the book of Esther who unsuccessfully tried to eradicate the Jews. ${ }^{137}$ Louis Bauman likened him to a "scalping Apache" and thought it was possible that he could be associated with the "red horse" among the four horsemen of the apocalypse described in the sixth chapter of Revelation. Bauman, along with most dispensationalists, followed the commentary in the Scofield Reference Bible that identified the rider on the white horse as the Antichrist, while the rider on the red horse was identified with the coming of war. Nazism exhibited "the spirit of the Antichrist" and Hitler himself was "an outstanding embodiment of the spirit of the Antichrist." He was described as a "Deified Demon," a "demon-possessed maniac" and a German "Rahu," a Hindu snake demon. Bauman conceded that Hitler's evil and perceived power would make him a candidate for the Antichrist but the "prophetic seer will keep his eyes fixed, not upon the banks of the Rhine, but upon the banks of the Tiber!"138 Brown also claimed

\footnotetext{
135 Wilson, Armageddon Now!, 27, 114-118. The quote from Ezekiel is from the KJV.

136 Brown, Eleventh Hour, 29.

137 See Gaebelein, Hope of the Ages, 170; Keith L. Brooks, The Jews and the Passion for Palestine in the Light of Prophecy (Los Angeles: Brooks, n.d.), 24.

138 Bauman, Light From Biblical Prophecy, 112, 110; Louis Bauman, The Time of Jacob's Trouble, $3^{\text {rd }}$ ed. (Long Beach, CA: n.p., 1939), 31, 35, 40. Both are reprinted in Louis S. Bauman, Biblical Prophecy in an Apocalyptic Age, Selected Writings of Louis S. Bauman, ed. Joel Carpenter (New York: Garland, 1988); Louis Bauman, "The European
} 
it was impossible that Hitler would prove to be the "little horn" described in the book of Daniel. ${ }^{139}$ Hitler's relegation to a secondary role illustrates that while threat perception is part of how Antichrists get identified and there is a great deal of flexibility in dispensationalist prophetic application, it is not infinitely malleable and there is an identifiable tradition of interpretative patterns that exert an influence.

Their prophetic geographical interpretations not only heavily influenced dispensationalist speculations regarding the Antichrist, it guided their expectations regarding international affairs more generally. They watched the various interactions between nations, both friendly and unfriendly, explaining how new developments fit into the prophetic framework and if they did not, explaining why they would be short lived. Given some of the twists and turns that took place during the interwar period, this meant that at times dispensationalists were able to claim that events were confirming prophecy. Events that contradicted prophecy could be dismissed as temporary.

No matter what international events seemed to portend, dispensationalists were consistent in their expectations regarding the eventual alliance between Russia and Germany. Already in 1904, Arno Gaebelein expected they would cooperate one day to attack Israel. ${ }^{140}$ Since they expected Germany to be part of the Russian led Northern Confederacy, any hints of a rapprochement got dispensationalists' attention. They saw the 1922 Rapallo Treaty that canceled war claims and reestablished diplomatic relations between the Soviet Union and Germany as a first step toward the coming alliance. Shortly after that somewhat modest agreement The King's Business claimed that “[p]rophetic students have long seen the probable

\footnotetext{
Imbroglio: The Antichrist Marching On," King's Business, November 1938, 369. The white horse is mentioned in Revelation 6:2 and the red horse is mentioned in Revelation 6:4.

${ }^{139}$ Brown, Eleventh Hour, 40.

${ }^{140}$ Arno Gaebelein, The Harmony of the Prophetic Word (New York: Fleming H. Revelle, 1904), 67.
} 
formation in the near future of the great Northern power spoken of in Scripture" and predicted more military cooperation in this "union of Germanized Russia."141 Dispensationalists consistently expected and predicted a more robust relationship in the near future throughout the interwar period.

In 1932 a MBIM editorial cited the map of the original Roman Empire along with past comments by Kaiser Wilhelm where he claimed Germany had "roots to the East" as support for its assertion that Germany would one day align itself with Russia. ${ }^{142}$ In early 1933 Bauman published a series planned for three articles in The King's Business where he explained that Germany and the Soviet Union were destined to ally together to attack Israel but would be defended by the Roman ruler. He conceded it seemed unlikely using human logic but stated that "[s]trange forces are at work these days" and foresaw a "three cornered fight" in Israel, superficially between "Communist and Fascist, Gog and the Beast" but really between both representatives of the fallen world against "The Stone" depicted in Daniel as crushing what the Scofield Reference Bible calls "the Gentile world system." The Roman Beast will be victorious against Gog, but it will be a short-lived victory after the hosts of heaven destroy him and his armies. Although the anti-communist Adolph Hitler became Chancellor of Germany as the second issue of the series was being printed, Bauman doubled-down on his prediction and extended the series to address objections. He argued that Hitler's ascension actually helped his argument, since the anti-Semitic nature of Germany's fascism meant an alliance with Italy was unlikely. If Hitler's persecution of the Jews did not result in a premature end like Haman, it could draw Germany and the Soviet Union together due to their shared animosity toward true religion. For Bauman, the anti-religious affinity he perceived between Germany and the Soviet

\footnotetext{
${ }^{141}$ Unknown, Notes Concerning Prophecy and Signs of the Times, King's Business, February 1923, 136.

142 Unknown, Editorial Notes, Moody Bible Institute Monthly, March 1932, 328.
} 
Union would prove to be a more powerful tie than the political affinity between Germany and Italy. Furthermore, whatever might make sense to man, God would work out his purposes that are laid out in prophecy irrespective of the supposed agency of these world figures. Bauman cites Ezekiel 38:4, where God is depicted as sinking his "hooks" into the jaws of Gog and his hordes (including Gomer) to send them on their ill-fated expedition. In fact, the Antichrist, in spite of himself "becomes the sworded servant of Israel's God for the execution of judgement upon Gog."143

To his credit Bauman never wavered from this prediction. After the 1938 Munich Agreement he noted that the Soviet Union was excluded and upset with France and England, or as he saw it, "forced to one side, to act her lonely part exactly as she must according to Ezekiel 38 and 39." While Bauman thought the improvement in relations between Italy and Great Britain fit into the Roman versus Russian end-time scenario, he did not expect the cooperation with Germany to last. The coming response to Nazi aggression would compel Germany to "seek an ally in the cave of the famous 'Bear."' His analysis of this international agreement illustrates how dispensationalists could simultaneously claim events vindicated their expectations as they dismissed aspects that were problematic. ${ }^{144}$ Dan Gilbert, a dispensationalist who tended to use more this-worldly arguments than Bauman and became one of the most prominent interpreters of current events during World War II era, also argued Russia and Germany were destined for cooperation, not conflict. He occasionally cited Bauman approvingly but he focused on the shared totalitarian natures of the regimes more than prophetic blueprints. ${ }^{145}$

\footnotetext{
${ }^{143}$ Louis S. Bauman, "God and Gog and 1937, part 2," King's Business, February 1933, 54-55; The reference to the stone is from Daniel 2:34, 35; Louis S. Bauman, "God and Gog and 1937, part 4," King's Business, April-May 1933, 133-134.

${ }^{144}$ Bauman, “European Imbroglio," 398.

${ }^{145}$ Dan Gilbert, Views and Reviews of Current News, King's Business, January 1939, 8-9, 17; Dan Gilbert, Views and Reviews of Current News, King's Business, June 1939, 213.
} 
Dispensationalists were never shy about claiming credit for accurate predictions and when Germany and the Soviet Union signed their short-lived German-Soviet Pact of Nonaggression in 1939, they would claim that their understanding of prophecy had been confirmed. Brown claimed the alliance did not make sense from a secular perspective but did from a prophetic one. Arno Gaebelein reminded his magazine's readers of the prediction made in his book 35 years before. Bauman pointed out his statements that were made over five years before the agreement was signed and illustrated the uniquely fundamentalist variant of empiricism when he denied any prophetic giftedness. Rather he claimed he "was not a prophet in 1934, even as I am not a prophet now. I simply believe that God's word cannot fail.” For Bauman and other non-Pentecostal dispensationalists, reading the signs of the times did not require special skill, secret knowledge, or unusual leading from the Holy Spirit. One just needed to trust what they saw as plain as day in the scriptures. ${ }^{146}$

Their prophetic framework not only meant that dispensationalists saw the German-Soviet Pact of Nonaggression as a fulfillment of prophecy that presaged a much greater degree of cooperation for these two countries, it meant they doubted the durability of another important agreement. Three months before the shocking German-Soviet pact, Italy and Germany had signed the "Pact of Steel," which required each country to come to the aid of the other in case of conflict. Many dispensationalists believed scripture clearly showed that it was doomed to fail. In the months before the pact became official, the editors of The King's Business claimed that any alliance between Italy and Germany would never last since Germany was not part of the original Roman Empire. After it had been inked, Bauman thought Rome was sure to drop out. He said a Russian, German, and Japanese alliance would fit "more perfectly into the prophetic

\footnotetext{
${ }^{146}$ Brown, Eleventh Hour, 155; Wilson, Armageddon Now!, 118; Bauman, Light from Biblical Prophecy, 30.
} 
chart." No one should buy into the idea "that the Roman's heart enters into the militaristic parades of the German cock of the walk." Rather, Mussolini was "playing the shrewdest game" and the pact was all part of his masterful strategy to manipulate Germany for his own ends. Bauman thought it was more likely that Mussolini was using the agreement with Germany as a way to intimidate France and Great Britain into being more amenable to an alliance with Italy, which would ultimately oppose the Soviet-German Northern Army. Alva Mclain, who was less confident that Mussolini would prove to be the final Caesar, nevertheless believed that if war did break out, Italy would desert Germany and make an alliance with the Jews. Gilbert agreed that the pact was unstable but mostly relied on secular newspaper reports of friction between the two countries to make his case. ${ }^{147}$

Throughout the interwar period dispensationalists filtered their interpretations of international events through their prophetic grid, whether they were earth-shaking agreements between powers like the Soviet Union and Germany or relatively minor discussions and rumors. Examples besides the issues discussed above include post-World War I negotiations between the Soviet Union and Japan, the controversy between Great Britain and Turkey over the administration of Mosul, cooperation between Italy and France, Mussolini's resistance to the Austro-German Anschluss, relations between Italy and Great Britain, and of course, anything relevant to the administration of Palestine and the possibility of Israel's statehood. ${ }^{148}$

\footnotetext{
147 Unknown, Around the King's Table, King's Business, January 1939, 8; Bauman, Light from Bible Prophecy, 20, 49, 43, 21, 22-24; Alva Mclain, “Daniel's Prophecy of the Seventy Weeks, Part 3," King's Business, August 1939, 298299, 324; Dan Gilbert, Views and Reviews of Current News, King's Business, July 1939, 253.

148 See, respectively Unknown, Editorial Notes, Moody Bible Institute Monthly, September 1924, 4; Pankhurst, World's Unrest, 61; L. Sale-Harrison, "League of Nations and the Coming Superman," Moody Bible Institute Monthly, August 1936, 605; Bauman, European Imbroglio, 369; Paul W. Rood, Around the King's Table, King's Business, September 1937,331.
} 


\section{The Romanization of Italy}

Mussolini not only explicitly equated his territorial ambitions with the Roman Empire, he and other Fascist intellectuals tried to associate the regime with ancient Rome in many other ways, invoking Rome in their rhetoric, holidays, monuments, and architecture. The Fascists propagated the theme of regeneration, and portrayed contemporary Rome as a modern, improved version of its once-lost self. Mussolini was often equated with Caesar, Augustus, and Rome itself. Fascist Party Secretary Achille Starace described an inextricable bond between his leader and the city that he called the "Rome-Mussolini binomial."149 By claiming Rome's legacy Fascists hoped to legitimize their rule and facilitate greater commitment from the masses. At a celebration of the founding of Rome Mussolini said, "Rome is our point of departure and our reference; our symbol, or if you wish, our myth." Emilio Gentile argues that this embrace of all things Roman and the corresponding increase in archaeological activity did not illustrate a reverence for the past as much as "an updating of the vestiges of Romanity" that would show "Fascism to be the inheritor and culmination of the Roman tradition." Fascist theoreticians like Giuseppe Bottai were clear about this, saying that for Fascists the idea of Rome was not "petrified" or "traditional" but rather had "the seal of Fascism" and was being remade in their image, conferred with "the fresh originality of the modern world."150

This Fascist understanding of Rome as possessing ancient continuity but also taking on a new and modern form actually matched dispensationalist beliefs pretty closely.

Dispensationalists breathlessly reported any statements or policies that revived the Roman legacy. Bauman found the increase in Latin usage in placards and signs for businesses,

\footnotetext{
${ }^{149}$ Eugene Pooley, "Mussolini and the City of Rome," in The Cult of the Duce, ed. Stephen Gundle, Christopher Duggan, and Guiliana Pieri (Manchester, UK: Manchester University Press, 2013), 209.

${ }^{150}$ Emilio Gentile, The Sacralization of Politics in Fascist Italy. (Cambridge, MA: Harvard University Press, 1996), 7677.
} 
restaurants and hotels "intensely interesting to the student of prophecy." He extensively quoted a London Times article detailing the ways that the "Latinization of Italy" was progressing and mentions a photograph of Mussolini at archeological diggings in Rome. For Bauman these were not merely examples of manipulating history and culture for contemporary political legitimation but were examples of prophecy being fulfilled. Israel had always been the focus of dispensationalist attention and for Bauman it was more than coincidental that when "the language of Abraham returns to the streets of Jerusalem (Zeph. 3:9), the language of Caesar returns to the streets of Rome."151 Bauman was not the only one who saw significance in archeological activity. In more than one work Pankhurst noted that remains from the time of Roman rule were being uncovered in the United Kingdom "with a strange frequency" suggesting that it was "more than accidental." She speculated that it might be a "portent that the Roman Empire is reviving" or even a way to prepare the British public for a future reconnection to it. ${ }^{152}$

The Fascist adoption of its namesake fasces as a symbol was a way to connect to the unity of ancient Rome that reinforced dispensationalists' perceptions of the Empire's revival. The bundle of rods bound by ropes while surrounding an axe could be a powerful stimulus to the prophetic imagination. Bauman saw its reappearance as a possible return of the same kind of axe that beheaded Paul, in time to commit the expected martyrdom of the end-times. Bauman saw it, along with the Swastika, the Hammer and Sickle, and even the Blue Eagle of the National Recovery Act, as at least a precursor for the "Mark of the Beast" mentioned in Revelation, while others were convinced the fasces was that mysterious mark. This led to conspiratorial and even occult speculations. The fact that the fasces was a widely used symbol by many governments

\footnotetext{
${ }^{151}$ Louis Bauman, There Shall Be Signs, The King's Business, June 1931, 245.

152 Pankhurst, Seeing the Future, 320; Christabel Pankhurst, The World's Unrest: Visions of the Dawn. (London: Morgan and Scott, 1926), 42.
} 
before Fascism meant that dispensationalists could find them everywhere. The Jewish convert to fundamentalist Christianity, Nathan Cohen Beskin, claimed he had found the fasces on hundreds of American products and that its presence on the American dime issued during that period was explained only by "[f]ulfillment of prophecy." One dispensationalist even reported an Italian child had been born with a fasces birthmark, although he was unsure if the story was the result of superstitious parents or a "Satanic miracle." Either way Fascism already had the symbol that would "one day be the world-wide sacrament of the Antichrist." 153

The dispensationalist focus on Mussolini and their arguments demonstrate that Antichrist watching cannot be reduced to threat perceptions. There were other candidates that were equally or more threatening to Americans in general and American fundamentalists in particular during this time period. Dispensationalist patterns of eschatological interpretation matter. When a plausible candidate seems to fit those historical patterns, they will have a leg up on other would be antichrists. The perceived revival of the Roman Empire and the self-styled "Romanization" of Italian society fit dispensationalist expectations to a much greater degree than previous threatening regimes like Wilhelmine Germany. The eschatological framework that had been in place at least a century also excluded for many dispensationalists godless world powers like the Soviet Union and Nazi Germany. That being said, this was not the first time Italy engaged in colonial expansion and the Savoy monarchy had ruled Italy since 1861. The monarchy persisted throughout and even beyond Mussolini's rule and yet none of the Italian kings or other leaders of political Rome were a major source of speculation until Mussolini came on the scene. If ignoring the importance of eschatology is problematic, so is ignoring the way that perceived

\footnotetext{
${ }^{153}$ Louis S. Bauman, "Socialism, Communism, Fascism: Three Unclean Spirits Like Frogs," King's Business, June 1935, 214; Beskin, "Mark of the Beast," 8; Charles Trumbull, Prophecy's Light on Today (1937; repr.; New York: Garland, 1988), 99.
} 
threats, anxieties, and even domestic controversies shape and intensify the ways that dispensationalists viewed the Antichrist. If this chapter succeeded in illustrating the powerful role that eschatology plays, hopefully the next will illustrate how Mussolini and Fascism not only fit their theological expectations but were relevant to their more earthbound contemporary concerns. 


\section{CHAPTER III: THE ANTICHRIST AND CENTRALIZATION}

Although Rome's perceived revival seemed to fit perfectly into dispensationalist eschatology, their fascination with Mussolini cannot be reduced to geography. They, like many Americans, had concerns with political, military, economic, and ideological trends that seemed to point in the direction of greater centralization in these areas. Unlike other Americans, it is something their theology taught them to expect. Dispensationalists believed the Antichrist would come to dominate the entire world-politically, militarily, economically, and spiritually. Bauman noted the ubiquitous use of "mass" as an adjective in popular culture and argued that it was a Biblically predicted trend. He cited a British paper that referenced the need for individuals to work together with "one mind" for the benefit of society and used the term "Mass Man." Bauman saw this concept prophesied in Revelation, when the ten kings are said to "have one mind, and shall give their power and strength unto the beast." For Bauman, there were signs everywhere "[p]aving the way for the reign of the Mass Man." He could find many examples of "the consolidation of our moral, social, religious, industrial, educational, and political life; so that the whole structure of human activity can be brought readily and easily under the control of one gigantic corporate mind." These trends were not only portents of the end, they were troubling in their own right. Bauman's brand of prophecy-watching was much less focused on averting disaster than many subsequent dispensationalists and he usually sounded thrilled the prophetic schedule was moving along, but even he belied his anxiety over these changes, lamenting "the sacrifice of the free individual" and warning "the United States of America, earth's freest nation, ever before in the vanguard of human liberty, is in grave danger of rendering her rich heritage of freedom to a coming Mass Man."154 Even as they looked forward to a glorious eternal destiny,

\footnotetext{
154 Louis T. Bauman, Present-Day Fulfillment of Prophecy, King's Business, January 1932, 5-6; Bible quote is from Rev. 17:13;
} 
Bauman and others did not relish the idea of losing their political and economic freedoms and their published work illustrates their anxieties. Their eschatology gave them an ultimate hope of salvation but also led them to be pessimistic about the future of democracy and capitalism. Mussolini was not only the head of a revived Rome, he was a central figure in both secular and religious discussions of these centralizing tendencies. This confluence of earthly concerns and spiritual expectations made for a particularly intense interest in Mussolini as a possible Antichrist.

\section{The Antichrist as Dictator}

While the association with Rome and its imperial expansion was important, so was the nature of Mussolini's rule. Dispensationalists closely watched global trends and the proliferation of dictatorships fired their imagination. Dictatorships were not only perceived as a threat to democracy but as having prophetic importance. They knew from Revelation 13:7 that the Antichrist would have "power over all kindreds, and tongues, and nations." Therefore, he was expected to be an all-powerful political leader. They thought they recognized an "ominous shadow" of the Antichrist's political system in the rule of the various dictators that emerged during this time period. ${ }^{155}$

Even before the spread of dictatorships became apparent in the 1920s, dispensationalists thought they saw a precursor in the Wilsonian expectations during the Great War that democracies would proliferate once the Allies were victorious. Echoing their theological understanding of God submitting humankind to tests that they would fail in each dispensation, they saw the increase in democracy as a way to test and show people that they were unable to

\footnotetext{
${ }^{155}$ Rev. 13:7 (KJV); Unknown, The Passing and the Permanent, Pentecostal Evangel, February 20, 1937, 7.
} 
govern themselves. The ensuing chaos would result in a turn to authoritarianism, making the Antichrist's form of governance more likely. ${ }^{156}$

With the economic and social upheaval after the war in places like Italy, they did not have to wait very long to see an increase in non-democratic forms of government. Dispensationalists were not the only Americans to watch this trend closely. Americans in general paid attention to this phenomenon but their view of dictatorships was "more multifaceted and ambivalent" than it would become in the later 1930's. While a relatively small number of Americans saw dictatorship as an attractive system for the United States, the concept did not possess the uniformly negative associations that would later emerge and the dictators themselves, especially Mussolini, enjoyed a mixture of negative and positive perceptions. The dictator represented something powerful, romanticized, and since it was perceived as a European phenomenon, non-threatening. The Studebaker car company even named one of their models the "Dictator." This changed by the mid-1930s as dictatorships and dictators themselves began to take on the more consistently negative associations that are more familiar to the modern reader. Benjamin Alpers identifies several reasons American perceptions changed. The Great Depression resulted in short-lived calls for temporary dictatorial powers by some commentators that made the threat of dictatorships seem much closer to home. In fact, many of President Roosevelt's critics, including dispensationalists, used that label to oppose his interventionist economic policies. In response to these criticisms, Roosevelt and his defenders went to great pains to distinguish between American democracy and dictatorship, resulting in a bigger perceived gulf between the two systems than before the Depression. Alpers argues that voices from big business became disillusioned with Mussolini's corporatist economic system (which

\footnotetext{
${ }^{156}$ Weber, Living in the Shadow, 121-122; James McAlister, "Startling Signs of the End Times," in Startling Signs of Great World Changes Soon to Take Place, ed. D.M. Panton, James McAlister, A. Sims (Toronto: A. Sims, n.d.), 6-7.
} 
will be discussed below), which undermined support for his dictatorship in some of the American quarters that had expressed the most sympathy for his regime. But for Alpers the most discrediting turn of events was the 1933 rise to power of Adolph Hitler and National Socialism in Germany. Hitler was not only more brutal from the beginning of his rule, but Alpers points out that his victims had more powerful and sympathetic constituencies in the United States than Mussolini's victims: Jews, labor unions, and Christians that opposed him compared to Communists, the Mafia, and Italian Freemasons. Alpers argues that Hitler enjoyed much less support in the United States than Mussolini. Furthermore, support for Hitler was much more likely to be qualified and expressing that support publicly quickly became much more discrediting. As Hitler became the preeminent dictator, dictatorship as a political system became more likely to be perceived in an unambivalently negative light. ${ }^{157}$

Dispensationalists shared some of this early ambivalence. But while their attitudes were affected by broader American trends, their eschatology did result in some unique perceptions. Their prophetic understanding both seemed to heighten their awareness of the dictatorial threat, and increased their sense of democracy's shortcomings. And the spread of dictators certainly caught their attention. In 1924 Pankhurst observed "[t]he fashion is all for dictators now," and noted that the trend spanned the political spectrum from "the reddest Reds" to the "conservative elements who hope for a strong man who shall make an end of social and industrial rest." She believed this development was "humanly unforeseen but biblically foreshown." 158 Dispensationalist periodicals frequently cited secular sources describing the spread of dictatorships. The Pentecostal Evangel thought it was significant that Revelation speaks of ten

\footnotetext{
${ }^{157}$ Benjamin L. Alpers, Dictators, Democracy, and American Public Culture (Chapel Hill, NC: North Carolina Press, 2003), 15-40.

158 Pankhurst, Pressing Problems of the Coming Age, 115; Pankhurst, The World's Unrest, 80.
} 
kings with no kingdom but who "receive authority of kings" and said it was "difficult to resist the conclusion" that John was describing the uncrowned present-day dictators. ${ }^{159}$

Italy in particular served as an example of how modern tyranny manifested itself in a different form than traditional monarchy. King Victor Emmanuel III remained the constitutional source of power and Mussolini did continue to follow the procedural formality of having the king sign off on his decisions, but by 1926 no one was under any illusions as to who held the real power. In 1939, King Victor himself told an American diplomat who was sent by President Roosevelt to make a last-minute appeal to avoid war that he was only a constitutional monarch and could do nothing, before changing the subject to how his fishing was going. He did ultimately relieve Mussolini of his duties and have him arrested but only in 1943, after the disaster of the war cost the Duce all credibility, and in response to a vote by the Grand Council of Fascism. This was only a few years removed from our period of interest but was light-years away regarding Mussolini’s prestige and therefore, his power. ${ }^{160}$

Dispensationalists during this period saw King Nebuchadnezzar's dream that was interpreted by Daniel as a prediction of this trend. The king saw an image of a large statue with a head of gold, chest and arms of silver, belly and thighs of bronze, legs of iron, and feet that were a mixture of iron and clay. A stone smashed the statue to pieces and turned into a mountain that "filled the whole earth." Daniel explained to Nebuchadnezzar that the various components stood for a succession of kingdoms that would end with God's kingdom (the stone) that would last forever. ${ }^{161}$ Dispensationalists believed those kingdoms could not only be equated with

\footnotetext{
159 Unknown, Editorial Flashpoints, King's Business, April 1927, 202; Unknown, The Passing and the Permanent, Pentecostal Evangel, February 20, 1937, 7.

160 David L. Kertzer, The Pope and Mussolini: The Secret History of Pius XI and the Rise of Fascism in Europe (New York: Random House, 2014), 390-391.

161 This account is found in Daniel 2:31-45.
} 
kingdoms that succeeded Nebuchadnezzar's Babylonian rule in the ancient Middle East, but like many Old Testament prophecies, had a double application to the end-times. Bauman surely exaggerated (and limited his population of relevant scholars to dispensationalists) when he claimed "all schools of interpreters" agreed that the clay imagery stood for democracy and the iron stood for autocracy, but that was a very common interpretation during the interwar period. Many believed the profusion of dictatorships alongside those countries clinging to their democracy meant we were in the predicted "iron and clay period" of the last days.

Dispensationalists believed that the "brittle, easily broken" nature of clay was not an accidental feature of the symbolism and some saw the stages of human government as degenerative. ${ }^{162}$

The perceived increase in dictatorships was a source of anxiety for dispensationalists, many of whom preferred democracy to other man-made and therefore fallible systems. Although they shared with other Americans the desire to have a say in how they were governed, theological and eschatological considerations meant their perspective on democracy was a bit more complex. Given their pessimism regarding the fate of fallen humankind they believed all forms of government would ultimately fail. Some dispensationalists expressed a preference for the form of government that would finally come: a God-ruled autocracy. James R. Gray, dean and eventual president of Moody Bible Institute, argued that democracy was "the antithesis of autocracy - God's ideal of government," French Oliver argued that a theocracy was the Biblical ideal for a government, and Scofield called himself a "monarchist," if only in the sense of the coming rule of Christ. In the lead-up to America's entrance to World War I many dispensationalists were critical of Wilson's democratic rhetoric. They knew that even a

\footnotetext{
162 Bauman, Light from Bible Prophecy, 131; Unknown, "Dictatorship," Pentecostal Evangel, June 11, 1938, 15; Charles O. Benham, 101 Signs of Christ's Coming: X-Raying Today's Crisis, (Joliet,IL: Charles O. Benham, 1937), 28; Oliver, "League of Nations and Prophecy's Program," 926.
} 
successful war would not either end armed conflict or end tyranny. Furthermore, even if it was a plausible outcome, democracy promotion was not a legitimate reason for going to war. The war on Germany was in response to aggression, and utopian ideals regarding universal freedom were just transparent justifications that only fooled "thoughtless people." Despite their pessimism about democracy, they did not seem to be in a hurry to get rid of it in the United States. In the same article that questioned exporting it by force to Germany, the author expressed concern that war measures would undermine democracy at home. ${ }^{163}$

Stung by criticisms that they were not sufficiently committed to the war effort during World War I, dispensationalists were less likely to express ambivalence about patriotism, militarism, and democracy during the interwar period, but given the pessimism inherent to their eschatology it did not completely disappear. Even though he thought Mussolini's accomplishments and ambitions were an important sign of the coming end, Oswald Smith did not count himself among the critics of Mussolini's form of government. After all, "it takes a one man government to really do things" and he expected a similar set-up once the Lord returned. Most dispensationalists were loyal Americans who enjoyed democracy, but they also recognized it would ultimately fail as a political system and they had ample reason to fear the dictatorial trends they observed. They could always comfort themselves with the expected final outcome but even as pilgrims in this fallen world it was likely difficult to shake off all their unease regarding the concentration of political power that would lead up to the tribulation. Bauman illustrates this residual ambivalence as he made clear that he preferred democracy and repeatedly warned Americans not to "cravenly" give up "our precious blood-bought freedom," but almost in

\footnotetext{
${ }^{163}$ Weber, On the Road to Armageddon, 84; Oliver, "League of Nations and Prophecy's Program," 925; Unknown, "Will This Be the Last War?," King's Business, June 1917, 483; Unknown, "What Are We Fighting For?", King's Business, October 1917, 867.
} 
the same breath concluded that humankind was unable to save themselves and that a society made up of unbelievers had to curtail freedom. ${ }^{164}$

During the 1920s, much of their attention was focused outward on trends they observed in Europe, but the Great Depression alerted them to the possibility of dictatorship within their own country. These concerns were not limited to dispensationalists, but their eschatological interpretations led many of them to believe that the collapse of democracies was inevitable. As we will see below, their concerns about political centralization were closely connected to fears of economic centralization, but there was more than just state intervention in the economy that would produce dictatorships. A more broadly construed sense of lawlessness was creating conditions that would necessitate autocracy. For Bauman the trajectory was " $[\mathrm{m}]$ oral chaos, then anarchy, then dictatorship!"'165

It became extremely common to refer to the Antichrist as a dictator and at least two different pamphlets were entitled The Coming World Dictator. One article called him the "coming universal dictator," "arch-dictator," and "superdictator" at different points. In another, the Babylonian King Nebuchadnezzar that appears in the book of Daniel was described as a "Babylonian dictator" who "lifted up his heart in dictatorial pride" against God. ${ }^{166}$ The Pentecostal Evangel linked dictatorships so closely with end times they even described Jesus

\footnotetext{
${ }^{164}$ Oswald J. Smith, When Antichrist Reigns (New York: Christian Alliance, 1927), 38; Bauman, "European Imbroglio, 399; Louis T. Bauman, "Socialism, Communism, Fascism: Three Unclean Spirits Like Frogs," King's Business, May 1936, 171; Louis T. Bauman, NRA: The Sign and its Spiritual Significance (Long Beach, CA: n.p., 1933), 4,9. Reprinted in Louis S. Bauman, Biblical Prophecy in an Apocalyptic Age, Selected Writings of Louis S. Bauman, ed. Joel Carpenter (New York: Garland, 1988).

165 Bauman, NRA, 8.

166 See, respectively, Paul Rader, The Coming World Dictator (Chicago: World Wide Gospel Couriers, 1934); Talbot, Coming World Dictator; Ezra S. Gerig, "The March of Events," King's Business, February 1936, 44-45; Bauman, "Socialism, Communism, Fascism," 213.
} 
Christ as "the Divine Dictator." 167 The worldly versions were merely demonic distortions of where governance was heading for eternity.

The trend toward dictatorships was not only a matter of who was able to get into power and the resulting governing structure but also the result of a shift in ideology. The merits of democracy were being questioned during the interwar period, even before the depression intensified the perception that it may not be up to the task of solving modern problems. Fascists articulated perhaps the main alternative to liberal democracy during this period. Fascist ideology will be discussed more below, but Italian Fascism explicitly emphasized the priority of the State, but more importantly a state with unusual power held by a leader that encapsulates the spirit of the people in a way that democratic proceduralism was unable to. Emilio Gentile argues this "ideology of the leader" was "the distinctive cornerstone and basic element of fascist ideology." ${ }^{168}$ He credits Mussolini and Italian Fascists as creating this alternative model that heavily influenced other fascist and authoritarian regimes of the period. Contemporary dispensationalists would have agreed. Pankhurst claimed the "philosophy of dictatorship finds its chief exponent in the Fascist leader, Signor Mussolini." Paul Rader argued that not just autocracy but "Fascism, a new form of government, which has many characteristics of Anti-Christ's rule," was found in prophecy. ${ }^{169}$

By the end of the interwar period Arthur Brown would claim the "outstanding national and international trend during the past 25 years in national and international politics has been toward centralization of government control." For dispensationalists this centralization of power was interconnected with and had a causal relationship with the numerous other portents that time

\footnotetext{
167 Unknown, The Passing and the Permanent, Pentecostal Evangel, March 18, 1933, 5.

168 Emilio Gentile, The Origins of Fascist Ideology, 1918-1925 (New York: Enigma Books, 2005), 345.

169 Pankhurst, The World's Unrest, 83; Rader, Coming World Dictator, 40.
} 
was rapidly approaching the end. Given the evil and often war-like nature of these dictatorships, they were associated with dispensationalist expectations of increasing sin and conflict. For Brown, it was in dictatorial societies that "the abyss of blasphemy has been reached!" Concentrated political power also was closely connected to centralization in the spiritual realm. Pankhurst saw the rise of dictatorships as an indication of how easy it would be for the prophetic fulfilment of a "Superman exalting himself and claiming supremacy in all things—even things spiritual." ${ }^{170}$ As the preeminent dictator through the early years of this period, Mussolini personified the fears and the sympathies that dispensationalists felt toward that form of government. However, despite dispensationalist expectations to be raptured before their retirement, maybe the topic where anxiety and eschatology had the greatest convergence regarded the economy.

\section{Economic Collectivization and the Antichrist}

The consolidation of political power was not the only worrying global trend dispensationalists perceived that fit their prophetic expectations. Any trend that seemed to point to the possibility of greater economic consolidation both had eschatological implications and sparked anxieties about the loss of economic and personal freedom. Dispensationalists were typically hostile to what they saw as un-American socialist economic policies, and this was only amplified when the Great Depression set in and collectivist approaches were more likely to be entertained by politicians and academics. For them, these economic policies had an evil lineage that started long before Karl Marx. Giles Knight traced the "Communistic spirit" back to Satan's fall from heaven, who then passed it on to Cain. The flood temporarily extinguished it but Nimrod, a mysterious figure from Genesis, "a confirmed Socialist," reestablished that mindset

\footnotetext{
${ }^{170}$ Brown, Eleventh Hour, 48, 149; Christabel Pankhurst, The Lord Cometh (London: Marshall, Morgan and Scott, 1934), 104
} 
when he proposed building the Tower of Babel. Furthermore, in the dispensationalist reading of Revelation, the politically powerful beast/Antichrist figure would wield absolute economic control. Only those who received the "mark" or "the number of the beast" would be able to "buy or sell." ${ }^{\prime 171}$

Many dispensationalists thought they were observing worldwide trends in the direction of greater economic consolidation that would make this kind of control possible. Louis Bauman said that Christ's return would be preceded by "a world-wide consolidation, a gigantic monopoly, a colossal corporation, a titanic 'trust'- a 'trust of trusts"” headed by "the devouring 'beast." He saw mass production, "robot-facturing," larger and larger corporations, and increasing government regulation as necessary precursors that had arrived. ${ }^{172}$

If economic control was the only important variable, the Soviet Union would be the obvious choice for the Antichrist's location, but the prophetic geography was problematic, and as we saw above, the Soviet Union was much more commonly associated with the Northern Kingdom that was expected to wage war with the Antichrist towards the end of the tribulation. Nevertheless, dispensationalist attitudes to the Soviet Union and communism more generally help us get a sense of their opposition to economic collectivism. Dispensationalist articles often displayed a more visceral disgust with the Soviet Union, a bear with "blood-foaming jaws," than with Italian Fascism. Unlike Faber, who saw Russia's attack on the Antichrist (Napoleon) as virtuous, interwar dispensationalists seemed to relish the beating the Northern Confederacy would suffer at the hands of the Antichrist. They also seemed to approve of Mussolini's successful opposition to communists in Italy. It may seem odd to argue that dispensationalist fears, both prophetic and secular, of economic collectivization help explain their speculations

\footnotetext{
${ }^{171}$ Giles N. Knight, “Utopia," Bridal Call-Crusader Foursquare, May 15, 1935, 5, 10, 20; Rev. 13:17-18 (KJV).

172 Bauman, "Socialism, Communism, Fascism," 212.
} 
about an anti-communist like Mussolini. But there are reasons this is not as illogical as it sounds. Dispensationalists during the interwar period were uncomfortable with any form of economic centralization, not just the communist or socialist variety, and both Fascism and Mussolini had socialist roots that developed into an alternative vision of collectivism. ${ }^{173}$

Some fundamentalists of this era were not completely at ease with unfettered capitalism and many still harbored a more populist suspicion of wealthy businessmen. There was a probusiness thread among evangelicals that goes back at least to leaders like D.L. Moody in the late $19^{\text {th }}$ century, and wealthy businessmen helped bankroll not only Moody Bible Institute and its West Coast counterpart The Bible Institute of Los Angeles but also the publication of The Fundamentals (1910-1915), the multi-volume publication that gave the movement its name. ${ }^{174}$

Even so, among early dispensationalists there was more ambivalence about economic ideology than the modern Religious Right would later exhibit. Fundamentalists were consistently anti-Communist and often managed to tie the threat of socialism to almost any issue, but they also occasionally made statements that indicated they were not yet steeped in Chicago School apologetics for laissez-faire and were yet to feel unmixed appreciation for virtuous, job creating capitalists. In the early years, alongside opposition to economic radicalism, there existed a prophetic voice that called the unprincipled wealthy to repentance.

A ubiquitous feature of dispensationalist articles and books was the list of signs pointing to the fact that humans were nearing the end of the current dispensation. Blackstone's list in Jesus is Coming included "Rich Men" and cited warnings to the wealthy from the book of James that they "would weep and howl" because they "have heaped treasures together for the last

\footnotetext{
173 Bauman, "Socialism, Communism, Fascism," 172; See Herrstrom, "The Resurrection of an Empire," 358; Unknown, Editorial Notes, Moody Bible Institute Monthly, February 1934, 252;

174 Darren E. Grem, The Blessings of Business: How Corporations Shaped Conservative Christianity (New York: Oxford University Press, 2016), 19-21, 38.
} 
days." He saw the continual growth of the estates of "financial kings" in Isaiah 5:8: "Woe unto them that join house to house, that lay field to field" and wondered how far this concentration of property might go. ${ }^{175}$

Frank Bartleman, a preacher who participated in the Azusa Street revivals that spawned the modern Pentecostal movement, was unafraid to challenge not only the evils of capitalism, but warmongering and nationalism. He blamed World War I on "national capitalists who used up the lives of common people for their own aggrandizement," along with "Wall street [sic] interests., pork barrel administration, brewers' corporation, syndicate and monopolist, steel trust and armor plate, powder trust, etc." and claimed that a "handful of rulers, capitalists, and ammunition makers are exploiting the whole human race for gain."176

The pacifism of early Pentecostalism may have made them more inclined to criticize capitalist motives, but fundamentalists also expressed discomfort with the byproducts of unfettered capitalism. The article on "The Church and Socialism" in The Fundamentals unsurprisingly was critical of socialism but also commented on the occasional cruelty of capital and the responsibility of some capitalists who were "grinding the faces of the poor" for class conflict. Before the first Red Scare (1917-1921) they even sometimes expressed sympathy for striking workers. The King's Business published an editorial entitled "Wicked Follies of the Rich" called the extravagant living wealthy "the real authors of the most desperate and dangerous forms of anarchy."177

\footnotetext{
175 Blackstone, Jesus is Coming, 234. The quotes from James are from 5:1 and 5:3 (KJV).

${ }^{176}$ Frank Bartleman, "The War-Separation," The Bridegroom's Messenger, January 1, 1916, 4; Frank Bartleman, "War and the Christian," The Bridegroom's Messenger, February 1, 1916, 4.

177 Grem, Blessings of Business, 22; Sutton, American Apocalypse, 182-184; Unknown, "Wicked Follies of the Rich," King's Business, February 1917, 99-100.
} 
Even as views hardened against unions during the interwar period, some of them continued to criticize excessive inequality, large corporations, and wealthy individuals who were selfish with their profits. The verses from the fifth chapter of James that Blackstone used earlier were commonly cited by fundamentalists of this period. Some dispensationalists expressed a concern about forms of collectivization and bigness that went beyond a simple fear of the proletariat taking over the means of production, Bolshevik-style. Often in the same paragraph that they railed against communism they warned of massive corporations that exploited the masses. Like Blackstone a few decades earlier, Bauman's extensive list of signs of the times include both the "outcry of the proletarian" and the "howling of the capitalist." While he espoused the capitalist talking point that some wealth accumulation was necessary to create employment, it also served "the selfish purposes of certain capitalists." Bauman distinguished between the deserving, useful wealthy and "unrighteous corporate wealth." Arthur Brown was less measured in his criticism, claiming "God hates Big Business, or world commerce," and condemned "the spirit of commercialism" that permeated the world and ruined many Christians. Unintentionally sharing the viewpoint of their Marxist enemies, some of them understood that exploitation and radicalism could be causally linked. That is not to say that they had any sympathies for Marxist solutions. In fact, at times they sounded skeptical of any earthly solution, and consistently saw the restriction of economic freedom as a cure worse than the disease. Even strikers were portrayed as tyrannical, "whose leaders bore names unpronounceable to an American tongue." ${ }^{178}$

While they shared a fear of communism with big business advocates of a more laissezfaire system, the strong link between fundamentalists and what is labeled "conservative"

\footnotetext{
${ }^{178}$ Bauman, Light from Bible Prophecy, 134-135; Brown, Eleventh Hour, 118-119; Louis T. Bauman, "The Death Struggle of Two Tyrannies," King's Business, January 1937, 12.
} 
economics had yet to be established. The latter part of the interwar period is when the foundations of this closer connection were laid. Several scholars have recently examined the origins of this odd marriage. Sarah Ruth Hammond and Darren Grem have both shown how upwardly mobile, lay "entrepreneurial Evangelicals" played a major role in the 1930s in developing the close relationship between Evangelical religion and anti-labor welfare capitalism that would be strengthened during World War II and be consolidated during the Cold War. Kevin Kruse describes the deep connections between wealthy industrialists and influential clergy that developed in the late 1930s to spread the Gospel of Jesus Christ alongside the Gospel of free markets, creating what Kruse calls "Christian Libertarianism." Even so, those vociferous free market advocates were as likely to be theological liberals like James Fifield, the Congregationalist minister of a glamourous Los Angeles church who founded the free market organization Spiritual Mobilization, as fundamentalists, who still had limited cultural pull outside their own community. The strong theological and economic correlation was to come later, as the neo-evangelical movement gained social and political clout. ${ }^{179}$

Organized religious advocacy against economic collectivization emerged simultaneously but distinct from secular, more academic initiatives. Scholars from several countries that shared a concern with growing collectivization first met in 1938. World War II put their collaboration on hold, but in 1947 they formed the Mont Pelerin Society, spawning the "neoliberalism" that became associated with "Chicago School" economics in the United States. These movements

\footnotetext{
${ }^{179}$ Sarah Ruth Hammond, God's Businessmen: Entrepreneurial Evangelicals in Depression and War (Chicago: University of Chicago Press, 2017; Darren Grem, The Blessings of Business: How Corporations Shaped Conservative Christianity (New York: Oxford University Press, 2016); Kevin Kruse, One Nation Under God: How Corporate America Invented Christian America (New York: Basic Books, 2015), 7.
} 
quickly began to overlap, as by 1947 Spiritual Mobilization was advertising Friedrich Hayek’s The Road to Serfdom in its magazine. ${ }^{180}$

After the conservative consensus developed during the second half of $20^{\text {th }}$ century, it became useful, if overly simplistic, to explain that economic conservatives feared the overly interventionist state, while economic liberals feared the damage that could be done by unregulated business interests. These developments were in embryo or still to come during our period of focus. Therefore, interwar fundamentalists, at least the clergy who published on prophecy, seemed less Manichean than their successors when it came to assigning blame for class conflict. Probably more consistent with their understanding of a fallen world destined for a looming destruction, they could still see the potential for evil among not only a radicalized proletariat but also for the capitalist. Bauman wrote about the "tyranny of the unregenerate havenots" and their struggle with "the unregenerate haves" that left freedom "bleeding and dying." The fifth chapter of James reads mostly as a jeremiad against the exploitative wealthy, and Bauman used it that way, but he also interpreted it as a prophetic warning of coming class warfare and as a text to criticize the Roosevelt administration that he believed was exacerbating those tensions. What is clear from dispensationalist sources is that there is a great deal of anxiety over economic issues, including the failures of capitalism, the perceived loss of freedom that collectivist responses entailed, and the disorder that would result from class conflict. ${ }^{181}$

This more nuanced view should not be overstated: they uniformly opposed overturning the capitalist system and more ink was spilt criticizing socialism. They were as likely to blame

\footnotetext{
${ }^{180}$ Kruse, One Nation Under God, 19. For a history of the Mont Pelerin Society and its influence see Angus Bergin, The Great Persuasion: Reinventing Free Markets since the Depression (Cambridge, MA: Harvard University Press, 2012).

${ }^{181}$ Bauman, "Death Struggle of Two Tyrannies," 10; Louis T. Bauman, "1935-A Prophetic Review," King's Business, April 1936, 128-130.
} 
the excesses of capitalism on the sinful motives of individual capitalists as problems inherent in the system. But importantly for our purposes, it meant that they were more open to recognizing forms of economic collectivization that did not just fit the socialist model. They also were more "conservative" than their reflexively pro-capitalist, pro-big business successors in that they had a more holistic fear of bigness, whether that took the form of a large proletariat movement, a powerful state, powerful corporations, or as in the case of Italy, a powerful state working in conjunction with industrialists.

The ideological trajectory of Frank Norris, "The Texas Tornado," who pastored megachurches in Dallas and Detroit simultaneously, serves as a stand-in for the trend among fundamentalists more generally. His early career was characterized by a populist sensibility that was extremely critical of economic elites, and during the first few years was very supportive of the New Deal. In his 1934 article "Fifteen Bible Reasons Why I Support Roosevelt's Recovery," he said that if people wanted to call it socialism "To hell with your socialism or whatever people want to call it! People are starving!” By the end of the thirties he had completely shifted, associating the New Deal with Russian Communism, calling Roosevelt a dictator, and severely criticizing the unions that agitated in his new part-time home of Detroit. ${ }^{182}$

Most dispensationalists did not experience as abrupt of a change as the temperamental Norris did but a growing fear of centralization not only in Soviet Russia, but within the United States was common. As governments tried to respond to the Great Depression it became clear that there were potentially many different paths to collectivization besides violent revolution or even more peaceful socialist reform. For both earthly economic and prophetic reasons,

\footnotetext{
${ }^{182}$ Frank Norris, "Fifteen Bible Reasons Why I Support Roosevelt's Recovery," Fundamentalist, March 23, 1934, 6. Cited in Barry Hankins, God's Rascal: J. Frank Norris and the Beginnings of Southern Fundamentalism (Lexington, KY: University Press of Kentucky, 1996), 97.
} 
dispensationalists were extremely wary of the varieties of government intervention, including those that came with the New Deal. Dispensationalist preacher John R. Rice criticized how the New Deal was leading the United States away from "old time American standards" and asked if America would "go Communist, Socialist, or Fascist?" as if one of those outcomes was inevitable. $^{183}$

These critiques became ubiquitous in dispensationalist periodicals in the mid-1930s. Bauman thought the National Recovery Administration was creating government power that "corresponds amazingly" to the Antichrist's rule and that the "economic dictatorship" ushered in by Roosevelt was predicted by John, the author of Revelation. He quoted those calling for a "central brain" to manage the economic recovery and responded, "Satan will supply." Bauman lamented the first American female cabinet member, Frances Perkins, as the "'Red-tinged' Secretary of Labor, and that a woman." MBIM cited a secular professor calling for a "speedy" government that would make the necessary economic interventions and their editors responded that when the Beast appeared he would "represent a very speedy government indeed." J.A. Saynan claimed Roosevelts "brain trust" was made up of many "communistic and perhaps atheistic college professors" and that the National Industrial Recovery Act was "the practical socialization or communization of industry." If successful, it would lead to international dictatorship. Paul Rood thought Roosevelt's 1936 re-election indicated that the efforts of "the socalled 'brain trust' to repudiate our cherished national principles" was supported by the American electorate, and an indication of Christ's imminent return. ${ }^{184}$

\footnotetext{
183 John R. Rice, “What Will Happen in 1935," Sword of the Lord, January 4, 1935, 1.

184 Bauman, NRA, 13; Louis T. Bauman, Present-Day Fulfillment of Prophecy, King's Business, June 1933, 180; Bauman, "Socialism, Communism, Fascism," 212; Unknown, Editorial Notes, Moody Bible Institute Monthly, November 1933, 96; J.A. Saynan, "The Antichrist A Near Political Possibility," The Advocate, January 11, 1934, 2; Paul W. Rood, Around the King's Table, King's Business, January 1937, 4.
} 
In sum, American dispensationalists expected to see greater economic concentration for prophetic reasons, but also expressed a great deal of anxiety about all forms of it and for how it would change the American way of life they preferred. Their anxieties were broader than their more single-minded anti-Communist predecessors would be during the Cold War. They feared big business consolidation and exploitation, along with economic radicalism, government intervention, and union agitation. Therefore, Fascism seemed as likely a vehicle as any for the coming world-wide economic dictatorship.

Fascism, especially in its embryonic form, did in fact possess Leftist economic strands and did not fit neatly anywhere on a Left-Right economic continuum. Some non-Italian (but less successful) forms of fascism, especially the Romanian variety, managed to maintain a largely proletarian membership and outlook. Even in retrospect there is a good deal of debate not only over the best way to describe Fascist economics but whether there is a discernable Fascist economic orientation. There may be room for disagreement regarding their actual practice, but it is indisputable that Fascists claimed to have a unique approach. Fascist intellectuals strived to transcend and solve the class struggle by finding a "third way," developing the concept of the "corporate state" where workers and owners would cooperate to advance the cause of the nation. ${ }^{185}$

Leftist accounts tend to emphasize Fascism's cooperation with and support received from big capitalism. The Comintern set the pattern for this perspective, calling Fascism "the open terrorist dictatorship of the most reactionary, most chauvinistic, most imperialistic elements of finance capital." This interpretation is understandable for Italian Fascism, given the violent

\footnotetext{
${ }^{185}$ Marco Palla, Mussolini and Fascism, trans. Arthur Figliola and Claudia Ratazzi Papka (New York: Interlink Books, 2000), 72-79; On the proletarian nature of Romanian fascism see Michael Mann, Fascists, (Cambridge, UK: Cambridge University Press, 2004), 261-295.
} 
attacks on Socialists in the name of "anti-Bolshevism" and opportunistic alliances it made with the rural propertied classes and big industrialists. The means of production remained in the hands of private capital and the alleged cross-class power sharing was mostly propaganda. Indeed, in the only two places fascism was able to gain and sustain power, Italy and Germany, they were assisted by establishment conservatives and business leaders who coveted their base of support, appreciated their attacks on socialists, and hoped to control them once in power. In both countries fascists rapidly gained more power than their conservative backers anticipated but as long as their property was protected, they probably did not mind very much. Nevertheless, the appearance of a working alternative to the failures of capitalism and socialism helped justify the regime beyond its borders. Even if the implementation of corporatism was superficial and Marxist analysis is mostly accurate it does not follow that Fascism was anti-collectivist. ${ }^{186}$

Fascism has been described as not only "violently anti-Bolshevik" but also "militantly anti-capitalist." The actual economic policies of Fascist Italy may have been accommodating to big business but the mix of "corporatismo" and "direct state intervention" exhibited more than sufficient levels of consolidation to suit many dispensationalists. Fascists undoubtedly failed in their attempt to bridge the class divide and once in power "tilted towards the capitalist class" but although property rights were maintained, business and industry were expected to serve the interests of the state. Corporatism was established in stages and there is debate over whether it actually followed a consistent or coherent path, but the idea was that "corporative assemblies" made up of workers, owners, and representatives of the state would work together to make decisions in their respective sectors of the economy that would advance the greater good. Mussolini argued that the corporative system took the "real needs which gave rise to socialism

\footnotetext{
${ }^{186}$ Paxton, Anatomy of Fascism, 102-106; Comintern quote in Bosworth, Italian Dictatorship, 50; Benito Mussolini, Fascism: Doctrine and Institutions (Rome: Ardita, 1935), 11.
} 
and trade-unionism" but rather than allowing them to be used "as a class weapon" the "divergent interests" in the economy "are coordinated and harmonized in the unity of the State."187

Mussolini's personal background also provided fodder for suspicion of his collectivizing tendencies. He was a vociferous socialist in his earlier years, even if his commitment was "skin deep" and he later argued that his experience of socialism was not "doctrinal." Even as Mussolini downplayed his socialist youth, he was very explicit that he thought capitalism had run its course and a new model was necessary. He thought capitalism entered a stage of decline after about 1870, when "the era of cartels, syndicates, combines, and trusts" begins. The "supercapitalism" that resulted "finds inspiration and justification in the Utopia of unlimited consumption," and resulted in a push for standardization that necessitated a turn to the State to support it. He believed corporatism would improve the "wealth, political power and well-being of the Italian people" in a way that was impossible in liberal capitalism or socialism. Lest there remained any confusion regarding his view of capitalism, he claimed that just as the establishment of the Fascist Grand Counsel in 1923 had buried political liberalism, the 1933 resolution regarding the corporate state was "burying economic liberalism as well."188

For our purposes an accurate understanding of Fascism's economic ideas and the actual effects of their policies may be less important than ascertaining how they were perceived by Americans in the interwar period. Most of the important speeches and writings by Mussolini on corporatism were widely available in the United States, translated into English and published shortly after they appeared in Italy. Corporatism elicited a variety of responses in the United States. American labor mostly saw it as a way to undercut and control unions, and liberal

\footnotetext{
187 David Baker, "The Political Economy of Fascism: Myth or Reality, or Myth and Reality," New Political Economy 11, no. 2 (June 2006): 231, 234; Mann, Fascists, 360.

188 Peter Neville, Mussolini, (London: Routledge, 2004), 27. Benito Mussolini, The Corporate State (Firenze, ITL: Vallecchi Editore, 1936), 13, 16, 23.
} 
thinkers were a mixed batch, some downplaying the militarism and admiring the "cohesive features" of corporatism, while others took the more menacing aspects of Fascism seriously and saw it as "mere window dressing that cloaked the interests of unregenerate capitalists." 189

When the corporate idea was first announced in 1926 it resulted in "cautious curiosity" among American businessmen but when Mussolini began to make invidious comparisons to capitalism in 1927, more voices in that community began to criticize the shortcomings they saw in excessive regimentation of the economy. After the onset of the Depression, with their faith in laisse-fair temporarily shaken, some American businessmen saw Mussolini's economics as a plausible alternative to unrestrained capitalism and far better than communism. In 1934 Fortune ran a special issue on the Corporate State that was mostly positive regarding its economic accomplishments, although it did express some unease that in the future Mussolini would use his power to "bind capital" in the same way he had bound labor. Their admiration was short-lived as their opposition to the New Deal (in which they saw parallels to corporatism) grew and Mussolini's pronouncements became more explicitly anti-capitalist. What is clear is that Italy's economic ideology was a source of discussion and debate among Americans throughout the period. ${ }^{190}$

Dispensationalists were no different. They watched and commented on Italy's economic policies. Like many secular commentators, dispensationalists saw similarities between American responses to the Great Depression and Italy's corporatist response. Already in 1931 Bauman claimed that calls in the United States to implement "public machinery for planning and control" were "parallel with Russia's 'five-year plan' and likewise the political doctrines of the Italian Duce." Where they differed was that they interpreted corporatism through a prophetic prism.

\footnotetext{
189 Diggins, Mussolini and Fascism, 174, 234.

190 Diggins, Mussolini and Fascism, 159-167.
} 
Whether one considered it good, bad, or indifferent regarding its earthly merits, it would have been hard to ignore that it was a powerful form of collectivism that seemed to fit the world-wide move towards what was depicted in the thirteenth chapter of Revelation. ${ }^{191}$

As we saw above, communism was the form of economic organization most loathed by dispensationalists. Still, Mussolini's corporatism was more than sufficient in its degree of centralization and as an option taken seriously by many intellectuals, could be looked at as a more subtle form that the wily Beast could use to gradually consolidate power. Furthermore, dispensationalists emphasized the link between socialism and fascism and tended to lump different forms of economic and political collectivization together. Herrstrom plausibly pointed out that "Communism created Fascism" and although he was not addressing Italian Fascism, Dan Gilbert demonstrated these tendencies when he argued that Nazis and Soviets "feed off each other" and believed "the two nations were moving together within the common temple of collectivization." Gerald Winrod was addressing Italy's version when he argued that "from a prophetical viewpoint Marxism and Fascism look very much alike" and saw Fascism as an "illegitimate child of Communism." Bauman dismissed the "supposed differences" of socialism, communism, and Fascism claiming, "at bottom, they are very much alike."192

Another prolific dispensationalist, Ava McClain, saw the various prominent theories of government emerging during this time period as "distinct" and in conflict but ultimately all of them were examples of "collectivism." McClain used mostly geographic criteria to identify the four kingdoms that he believed would soon clash at Armageddon, but he thought it was extremely significant that they each possessed a different version of collectivism. Communist

\footnotetext{
191 Louis T. Bauman, Present-Day Fulfillment of Prophecy, King's Business, July 1931, 294.

192 Herrstrom, "The Resurrection of an Empire," 358; Dan Gilbert, Views and Reviews of Current News, King's Business, January 1939, 9; Gerald B. Winrod, Writings (Wichita, KA: Defender Publishers, 1936), 31. Bauman, "Socialism, Communism, Fascism," 213;
} 
Russia would lead the Northern Kingdom and Fascist Italy would represent the revived Roman Empire. He predicted the Eastern kingdom would be led by Japan, who he described as a "bureaucratic oligarchy based on Emperor worship, dominated by the military caste." Maybe his least intuitive claim was that the Kingdom of the South was represented by Great Britain, due to the control they exerted over Egypt. He said that even Great Britain's democracy was "yielding here and there to the pressure of Socialist and Fascist philosophies." For McClain this unprecedented alignment of politics and geography coupled with the application of force necessary to maintain collectivism would result in internal conflicts that would rapidly turn into external ones. World conflict would then only be solved by a global "vast supergovernment" like the one described in prophecy. ${ }^{193}$

Italian Fascism was mostly lumped with the other forms of economic and political collectivization but occasionally was identified as being particularly relevant to predictions about the Antichrist. MBIM directly tied the Corporate State to the "one mind" mentioned in Revelation 17:13 and Paul Rader saw Mussolini's political and economic system as uniquely suited to the Antichrist, calling Fascism "a corporation of corporations," where "economically and politically the State is EVERYTHING, it absorbs EVERYTHING, it does EVERYTHING." 194

The political and economic upheaval around the world, along with the centralizing tendencies sometimes observed in response to that upheaval, was a source of anxiety for dispensationalists, who despite their pessimism regarding this world's destiny, valued their notions of economic and political freedom. Their scriptural interpretations taught them to associate these developments with the coming of the Antichrist. Mussolini not only led a

\footnotetext{
${ }^{193}$ Alva J. McClain, "The Four Great Powers of the End-Time," King's Business, February 1938, 81-82.

194 Unknown, Editorial Notes, Moody Bible Institute Monthly, January 1934, 208; Rader, Coming World Dictator, 42.
} 
reconstituted Roman Empire, he was maybe the world figure that most embodied the trends of dictatorship and economic collectivization. To those looking for the signs, it was a powerful mix.

As important as politics and economics were to dispensationalists, their main priority was spiritual. More dangerous than the loss of political or economic freedom were attacks on the tenets of their understanding of Christianity. That was the most terrifying thing about the centralization described above. Dictatorship and economic control could facilitate spiritual centralization as well. Mussolini and Fascism fueled those anxieties and fit their prophetic expectations in ways that no one else could. It is to these fears of spiritual challenges to Christianity that we now turn. 


\section{CHAPTER IV: THE THREAT OF THE "ISMS"}

The centralized political and economic power of the dictatorships that dispensationalists observed was not the only thing that grabbed their attention. The ideologies that accompanied the application of power were also deemed important. Dispensationalists had concerns about the many different belief systems that they saw as a challenge to their understanding of Christianity. They embraced the labels of fundamentalism and premillennial dispensationalism, but they saw almost any belief system that did not apply to them as threatening. Since at least Blackstone, it was common for prophetic writers to list a number of ideologies that not only undermined the truth but were somehow linked. Dispensationalist publications were filled with news, warnings, explanations, and apologetic guidance regarding these deceitful ideas. In 1919 it cost $\$ 3.00$ for interested students to take a correspondence course from the Bible Institute of Los Angeles instructing them "[h]ow to meet modern isms."

Almost anything with that suffix was criticized somewhere in the pages of their magazines, as at least deluded, but often as evil. "Modernism" was the most prevalent term, referring mainly to liberal theology but also serving as a catch-all category for false teaching. It was called a "harbinger of the Antichrist" and perceived as an insidious force that affected everything. E.L. Pace, a popular fundamentalist cartoonist that appeared in most of the major dispensationalist periodicals, depicted modernism as an octopus, with its tentacles wrapped around several buildings, including a church, college, religious press, YMCA, YWCA, seminary, and a Sunday school. Bauman ridiculed "Socialists, Altruists, Utopians, ethical culturalists, humanists, Oxford Groupists, behavioralists, nudists, and every other sort of an amicus humani generis that can be classified under the term "modernist"' who thought they could solve this

195 “How to Meet Modern Isms," King's Business, August 1919. 
fallen world's problems without God. Besides the aforementioned ideologies, these ubiquitous lists included Communism, Bolshevism, Catholicism (or Romanism or Popery), relativism, rationalism, evolutionism, Darwinism, spiritualism, paganism, liberalism, New Dealism, materialism, Freudianism, Fascism, pacifism, nihilism, other religions, and a number of cults with Protestant origins. Counterintuitive connections were identified, and ancient origins claimed for even the most modern ideas. The King's Business equated German theology with "Mohammedanism," and The Church of God Evangel approvingly cited an Episcopal Bishop who equated Communism with paganism, but without the benefit of "spiritual ideas." In a "Warning Against Modern Cults" MBIM linked Christian Science, New Thought, and Theosophy to modernism, all of which can be traced "more or less directly to German philosophy," which possessed aspects of atheism, agnosticism, pantheism, and Hegelianism. It all leads to the "deification of man" that "was the teaching of Satan in Eden." N.J. Poysti borrowed from Dostoyevsky, equating socialism with an atheist attempt to build the Tower of Babel. These false philosophies not only had ancient origins, they would be part of the unbroken lineage from Satan's earliest lies to the coming false religion of the Antichrist. John Goben argued that the $20^{\text {th }}$ century representative of these ancient lies were the "Modernists! Up-todatists! Antichrists!" who should be labeled not as modernists but as "NOT OF GOD, HAVING THE SPIRIT OF THE ANTICHRIST."196

\footnotetext{
${ }^{196}$ Stanley H. Frodsham, "Modernism, the Harbinger of the Antichrist," Pentecostal Evangel, October 25, 1924, 5; E.J. Pace, "The Octopus," Moody Bible Institute Monthly, December 1925, 158; Bauman, "1935-A Prophetic Review," 128; R.A. Torrey, "The Prostitution of German Scholarship," King's Business, April 1918, 279-280; E.C. Clark, "Bishop Says Communism is Paganism," The Church of God Evangel, March 9, 1935, 3; Unknown, "'Philosophy and Vain Deceit' - a Warning against Modern Cults," Moody Bible Institute Monthly, November 1928, 101-102; N.J. Poysti, "What is Bolshevism," Pentecostal Evangel, February 1, 1936, 4; Goben, "The Revival of the Roman Empire," 4.
} 
These ideologies challenged the hegemony that they thought their understanding of Christianity deserved, and that they believed was America's heritage. Like the centralization they observed politically and economically, they saw these intellectual and religious trends as foreseen in prophecy. Dispensationalists believed the Antichrist would not only consolidate power and exert complete economic control, he would institute a false religion that rebelled against God's authority. Bauman argued that three "stepping stones" would facilitate the beast's ascension to power: political centralization, economic centralization, and spiritual centralization, and that this was all described in the $13^{\text {th }}$ chapter of Revelation. The Antichrist would speak blasphemies and those that refused to worship him would be executed. This made dispensationalists extremely wary of ecumenical calls for greater religious unity, even those that were limited to Christendom. T.C. Horton claimed that a "League of Churches would be a league with the devil." Maybe more threatening than the ominous organizational developments were the false ideas that seemed to be proliferating. Part of their opposition to world-wide Christian unity was their belief that not only Catholicism and Eastern Orthodoxy were in error, but that most of Protestantism was so permeated by modernist thinking it had fallen into apostasy. Although we will see that they thought the Catholic Church would play a major role in the career of the Antichrist, at times they sounded more critical of liberal Protestantism. James M. Gray said that unlike many liberal Protestants, the Catholic Church at least believed in the divine inspiration of scripture, although "each is doing its share to bring about the development of the "man of sin."” These ideologies that dispensationalists criticized were paving the way for the ultimate false ideology. They believed the "deification of man" in modern thinking would 
make it "natural and logical" to go farther and worship one man. The Antichrist "will be what the popes have long aspired to be- - head of the World-State, and head of the World-Church."197

\section{Fascism as False Religion}

Dispensationalists saw all false ideologies as precursors to the coming satanically inspired world religion, including those typically thought of as primarily economic or political ideologies, like Communism or Fascism. The anti-Christian elements of these ideologies were deemed especially significant. Here again, stories of anti-religious policies coming out of the Soviet Union provided plenty of fodder for speculation. But Mussolini's statements and Fascist philosophy were more than sufficiently anti-Christian to strengthen his candidacy for the Antichrist. Fascism's elevation of the state and explicit exaltation of power fit their expectations perfectly. ${ }^{198}$

Mussolini was extremely anti-religious in the years before Fascism came to power and a strong anti-clerical faction persisted within the Fascist party throughout his rule. Many dispensationalists mentioned his atheism as a young man and recounted incidents where he challenged religion. They included a debate with a theology professor, where he denied the existence of God and equated religion with "absurdity," "immorality," and "a disease." He also was said to have defied God to strike him down in the next five minutes. Dispensationalists were intensely interested in reports of a "Fascist Creed" that Italian school children were expected to commit to memory filled with idolatrous exhortations to "believe in the genius of Mussolini" and a reference to "our Holy Father Fascism." They saw it as a "blasphemous parody of our

\footnotetext{
197 Bauman, Light from Bible Prophecy, 154-155; T.C. Horton, "League of Nations and League of Churches," King's Business, June 1919, 491; James M. Gray, Satan and the Saint (New York: Fleming H. Revell, 1909), 117; Trumbull, Prophecy's Light on Today, 90; Arthur Pink, The Antichrist (1923; repr.; Minneapolis: Klock and Klock, 1979), 146; The verses relevant to spiritual centralization are Revelation 13:4-8, 15.

198 Smith, "Is Antichrist at Hand," 2.
} 
Apostles' creed." At least one dispensationalist saw the creed, "blasphemous in every line," as a revitalization of pagan Roman religion. Mussolini was quoted in the New York Times as saying, "If the Eternal Father were to say to me, 'I am your friend' I would put up my fists to him." E.J. Pace, the long-time cartoonist for the Sunday School Times, depicted a raised fist with "Mussolini" written on the forearm with that quote in the background in a cartoon entitled "The Spirit of Anti-Christ." Even as Mussolini became more conciliatory toward religion during his rule, dispensationalists saw these earlier anti-Christian expressions as a reflection of Mussolini's true character. D.M. Panton argued that Mussolini's combination of "absolute autocracy and fundamental irreligion" was at least a foreshadowing of the Antichrist's character and cited the Duce's embrace of Machiavelli's "devilish" philosophy. This animosity toward Christianity by such a powerful world figure was both a sign of the end times and a force moving the world toward the acceptance and worship of the Antichrist. ${ }^{199}$

It was not only Mussolini's personal views that were problematic. A look at the practices and ideas that made up Fascism makes it clear why dispensationalists would find it threatening. There is an immense body of literature on all aspects of Fascism and differing interpretations of how to best define it, how effective it was at shaping the Italian population's identity, and whether or not it even constituted a coherent ideology. Regarding the last question, scholars range from Emilio Gentile, who believes Fascism had identifiable intellectual roots that can be traced back to the pre-war Italian intellectual avant-garde, to Denis Mack Smith, who argues that

\footnotetext{
199 Bauman, "Reappearance of the Empire," 257; Winrod, Writings, 32; Talbot, The Coming World Dictator, 5; Bauman, Light From Biblical Prophecy, 18. Reprinted in Louis S. Bauman, Biblical Prophecy in an Apocalyptic Age, Selected Writings of Louis S. Bauman, ed. Joel Carpenter (New York: Garland, 1988); Unknown, "The Resurrection of the Roman Empire," Pentecostal Evangel, October 9, 1926, 1-2; John Carter, "Mussolini, Master of Italy," New York Times, February 7, 1926; E.J. Pace, The Spirit of Anti-Christ. Pen and Ink on Paper, 1926?, $28.5 \times 25 \mathrm{~cm}$, Digital Commons @ Biola https://digitalcommons.biola.edu/ejpace-cartoons/42/; D.M. Panton, The Panton Papers (1928; repr.;Miami Springs, FL: Schoettle, 1988, 87.
} 
Fascism even at the beginning was merely a method to win power, and Martin Clark, who calls it an "incoherent" mix of "syndicalists and bankers, revolutionaries and monarchists, anti-clericals and Catholics." Robert Paxton argues the answer to this question depends on which stage of Fascism you are trying to explain. Ideology did play an important role in Fascism's founding stage and reasserted its importance during the final war-time stage but during the middle stages when they looked to establish and consolidate their power he argues ideology became less important. Whatever the answer, the important thing for our purposes is that Fascists did make numerous claims about values and truth, and dispensationalists saw Fascism as one of the nefarious modern "isms" that challenged Christianity. ${ }^{200}$

Identifying the essential elements of Fascist doctrine is somewhat difficult since Fascists themselves made contradictory statements regarding the nature of Fascism and its ideology. In the early stages of Fascism, members denied having an ideology or even a concrete political program. One Fascist claimed "The fist is the synthesis of our theory" while another pointed to the Browning pistol. Shortly after coming to power, Mussolini claimed the Fascist program consisted of "breaking the bones of the democrats of Il Mondo," an Italian paper. Paxton points out that as the most recent of the competing "isms" of the time, it did not have a corpus of systematic doctrinal elaborations that it needed to demonstrate fidelity to. During his rule, Mussolini did attempt to codify a Fascist doctrine, if a somewhat ambiguous one, with "a form correlated to contingencies of time and space." It mostly prioritized the "State... as the expression of a universal ethical will" that had ultimate authority, was "totalitarian" and "interprets, develops, and potentiates the whole life of a people." ${ }^{\text {201 }}$

\footnotetext{
${ }^{200}$ For the various positions see Gentile, Sacralization of Politics; Smith, Mussolini, 138; Martin Clark, Mussolini, (Harlow, U.K.: Pearson, 2005), 164. Paxton, Anatomy of Fascism, 18-19.

${ }^{201}$ Cited in Bosworth, Italian Dictatorship, 39; Paxton, Anatomy of Fascism, 16; Mussolini, Fascism, 7, 11, 12.
} 
For dispensationalists, any ideology that claimed a higher loyalty than Jesus Christ was religious in nature and they used the term "statolatry" to describe Mussolini's regime. While the veracity of their perspective as applied to many political philosophies might depend on one's definition of religion, it was less of a stretch to see Fascism as a religious ideology. Emilio Gentile argues that the French Revolution spread the tendency to sacralize the nation throughout Europe and that Italy had been groping about for an effective "civil religion" ever since the $19^{\text {th }}$ century Risorgamento. Gentile claims that a lasting patriotic religion never really took hold during the Liberal period (1870-1915) that followed Italian unification. For him, the Fascist movement that developed after The Great War was able to successfully fashion a national religion in a way their predecessors could not. Fascists were not just using propaganda techniques to encourage consent and instill pride in the nation. Gentile argues that like religion, Fascism tried to transform the population's basic values and beliefs, its source of meaning, and its purpose, relegating those who resisted conversion to damnation. He even sees the rampant thuggery of early Fascist squadristis as "purifying violence" in a "holy crusade" against the nation's internal enemies. Gentile claims their expeditions against Socialists were an attempt to "redeem the proletariat from idolatry, from the false gods of internationalism, to reconstruct the symbols and holy places of the motherland, to bring the country back to the altar of civic devotion." ${ }^{202}$

Some scholars think Gentile's claim is overstated, including Stephen Gundle who thought that Mussolini's appeal is better understood by emphasizing the nascent celebrity culture of the age. Mussolini should be looked at more like a star than a religious figurehead. Given Gundle's

\footnotetext{
202 William Booth-Clibborn, "The Pulse of a Dying World," Latter Rain Evangel, September 1933, 13; Gentile, Sacralization of Politics, 1-3, 11, 69, 21-24. Gentile seems to use the terms "civil religion," "political religion," "patriotic religion," and "national religion" interchangeably here. Below we will see Fattorini distinguishes between "civil religion" and "political religion."
} 
argument that the "secularization of the modern era led to the attachment of sacred attributes to practices that were not strictly religious" and all areas of life were capable of "religious properties," this criticism seems to amount to a distinction without a difference, at least for how dispensationalists viewed Fascism and Mussolini. Whether or not all of Gentile's religious analogies are justified, there is ample evidence that the basic claims of his analysis would have been shared by Fascists themselves, and dispensationalists were adept at seeing the potential for idolatry in all manner of areas, be it politics, religion, or celebrity stardom. ${ }^{203}$

Fascism practiced martyrolatry extensively and a 1923 pamphlet published by the party called Fascism and Religion, referring to the solemn ceremonies that remembered the fallen, said the "silent meetings of the black-shirts with companions who have abandoned the earthly struggle are religion." One squadristi leader, at the funeral of three Fascists who were killed during one of their missions, equated them with the godhead, saying "O Holy Trinity, born of blood: your blood, our blood. The veins are emptied of their most vital flow to create a new baptismal font: the chalice full of its scarlet gift." The need for "faith" was a reoccurring theme in Fascist literature and Fascist journals and leaders often explicitly equated Fascism with religion, including Mussolini who said the "Fascist conception of life is a religious one," and saw the "Fascist State" as "a force, but a spiritual one" that "permeates the will no less than the intellect" and "dwells in the heart of the man of action" and the "soul of the soul." While Mussolini's conception of "spiritual" was probably quite different than that of the dispensationalists they cited him in their articles and agreed with his statements. Paul Rader said that the "Fascist state is a spiritual force" and some authors saw Fascism as one of the "three unclean spirits, like frogs" that according to Revelation would come from the mouth of the

\footnotetext{
${ }^{203}$ Stephen Gundle, "Mass Culture and the Cult of Personality," The Cult of the Duce, ed. Stephen Gundle, Christopher Duggan, and Guiliana Pieri (Manchester, UK: Manchester University Press, 2013), 72-73.
} 
dragon, the beast, and the false prophet, including Bauman, who authored an eight-issue series on the topic in The King's Business. ${ }^{204}$

\section{Fundamentalism, Fascism, and Modernity}

When dispensationalists criticized "modernism" they were usually referring to what they saw as God-denying doctrine, primarily what they saw as the apostatizing doctrine of liberal Protestants, but also scientism, atheism, or any other number of ideologies that they opposed. Often it was shorthand for all of them. But their writing also belied a discomfort with the experience of modernization more broadly. They had an adversarial relationship with modern science, modern education, innovations in the arts, and even seemed uncomfortable with many technological advances. Along with criticism of alcohol, dancing, movies (irrespective of the content), and modern forms of music ("an abandonment and defiance of the principles that make for beauty and truth"), the adverse consequences of cars were a common theme in their periodicals. Articles on the fatalities and even the negative economic consequences the increased mobility had on rural areas appeared. Any advances in weaponry were reported, usually tied to the inevitability of coming war with destruction never seen before. They even sometimes saw those advances prophesied in scripture. In the book of Nahum, which prophesied the destruction of Nineveh, the author writes "chariots shall rage in the streets, they shall jostle one against another in the broad ways; they shall seem like torches, they shall run like the lightning." Bauman said that the "simplest child, reading these words, would have but one vision - the automobile!" In Daniel, the author was told by God to seal up the book he had written until the end, when "many shall run to and fro, and knowledge will be increased."

\footnotetext{
${ }^{204}$ Gentile, Sacralization of Politics, 26, 27, 59; Mussolini, Fascism, 9, 13; Rader, Coming World Dictator, 50; Benham, 101 Signs of Christ Coming, 27-28; Louis T. Bauman, "Socialism, Communism, Fascism," King's Business, January-August, 1938; The verse on the unclean spirits is from Revelation 16:13.
} 
Dispensationalists saw examples all around them of human achievement generally and advances in transportation specifically that they believed were prophesied in this verse. Arthur Brown included the increasing speed of transportation as one of his twenty signs that pointed to the rapidly approaching apocalypse. Charles Benham, maybe possessing the keenest eye for modern developments that were foreseen in prophecy, included among his 101 signs: new explosives, submarines, airplanes, tanks, modern fighting ships, bombs, cars, "broad thoroughfares," telephones, telegraphs, and radios, each with corresponding scripture showing that prophets glimpsed and wrote about these inventions long before they appeared. They not only were fulfillments of prophecy in and of themselves, they pointed to a coming war that would make all previous wars seem insignificant in their destruction, which also fulfilled dispensationalist expectations. These interpretations belied a fear of where all this technological development was heading that could not be reduced to connecting eschatological dots, though the theological framework certainly intensified it. Their criticisms of these advances also seemed to betray a this-worldly sense of loss as lifestyles changed. Despite this discomfort with these various aspects of modernity, they were far from neo-Luddites and were often quick to embrace technology that they could use to advance the Gospel. They also were not as traditional in their theology as they often claimed. Dispensationalism was full of theological innovations and B.M. Pietsch argues that dispensationalist epistemology was based on modern assumptions and methods of taxonomy. Despite these contradictions, they saw themselves as defenders of ancient truths that were being constantly attacked in the modern world. ${ }^{205}$

\footnotetext{
205 Trumbull, Prophecy's Light on Today, 120; Bauman, Light from Bible Prophecy, 128; Bible quotation from Nahum 2:4 (KJV); Mary Winey Morris, Prophecy: What the World is Coming to in the Light of the Book of Revelation (Elgin, II: Brethren Publishing House, 1931), 82-84; Brown, Eleventh Hour, 135; Benham, 101 Signs of Christ Coming, 3138; B.M. Pietsch, Dispensational Modernism, New York: Oxford University Press, 2015.
} 
Like fundamentalism, fascism can be partly understood as a response to the perceived problems of modernity. But in a different way than fundamentalism, fascism also had a complicated relationship with modernity. It was formed in response to the perceived shortcomings of modern life, but its adherents saw fascism as the harbinger of a new future, not a return to some sacralized past. Juan Linz partly defines fascism by what it is against and includes many features associated with modernity. It is not only "anti-Marxist, anti-communist" and "anti-proletarian" but is also "anti-liberal, anti-parliamentarian," "anti-international," "anticosmopolitan," "anti-individualism," and some factions possessed "anti-urbanism," "antifeminism," and a "distinctive type of anti-capitalism." But he also argues it would be problematic to summarize all of this as anti-modernism. Fascism also possessed a strong anticlerical strand and was "in a very special sense, anti-conservative." Futurists were prevalent among the early Italian Fascists and while Fascism ultimately disappointed Futurist truebelievers, their emphasis on speed, action, machines, and perpetual change hurtling to an unknown future persisted in Fascist rhetoric and style. ${ }^{206}$

Zeev Sternhill sees fascism in general as a revolt against the industrial revolution and urbanization, going as far as to suggest it may have been "the first environmentalist ideology" of the $20^{\text {th }}$ century in its advocacy for a life that returned to "nature and the soil." Even so he disagrees with scholars who have called fascism "antimodern." Despite fascist criticisms of the comforts and corresponding emptiness of modern urban, bourgeoisie life and their usage of agrarian nostalgia, they availed themselves of the most up to date methods of propaganda and sought greater industrialization and technological developments to further their imperial

\footnotetext{
${ }^{206}$ Juan J. Linz, "Some Notes Toward a Comparative Study of Fascism in Sociological Historical Perspective," in Fascism: A Reader's Guide, ed. Walter Laqueur (London: Wildwood House, 1976), 16; On Futurism's relationship to early Fascism, see Gentile, Fascist Ideology, 86-103.
} 
ambitions. They also embraced the idea that they were creating a new future, a new man that would transcend the restrictions of both outdated tradition and modern sterility. Paxton argues that fascism in general can be understood as an "alternate modernity" intended to obliterate "modernity's strains and divisions." Michael Mann says that fascists saw dangers and crises in modernity but were not merely reactionary, but rather had "novel visions of modernity," even if fascism was best looked at as the "dark side of modernity." Gentile saw the "myth of 'conquering modernity"' as one of the consistent threads between the Italian pre-World War I avant-garde movements and Fascism, resulting in a "modernist nationalism" that did not oppose modernization but wanted to subordinate it to the interests of the nation. Other attempts to capture the essence of how fascism related to modernity includes a uniquely "Italian modernity," "reactionary modernism," and as a "conservative revolution." Roger Griffin reverses Gentile's label and therefore his respective emphases, calling Fascism "nationalist modernism" and argues that its glorification of ruralism and attempts to connect to a Roman past should "be read in a modernist key" and looked at as an attempt "to realize an 'Italian modernity."”207

Whatever the best way to understand how Fascism fits in with modernity, the movement possessed many characteristics that would grab the attention of a prophetic-minded fundamentalist who was uncomfortable with aspects of modernization. Fascists promised a new future and were in a hurry to get there, which corresponded to the dispensationalist sense of rapidly approaching change in all spheres of life that would lead to the eschaton. Even if Marxist scholars were accurate in their interpretation that Fascism was completely reactionary in the

\footnotetext{
207 Zeev Sternhill, "Fascist Ideology," in Fascism: A Reader's Guide, 341; Paxton, Anatomy of Fascism, 12-13; Mann, Fascists 354-355, 364-365; Gentile, Origins of Fascist Ideology, 388-391; Herf, Reactionary Modernism (New York: Cambridge University Press, 1984.); Fritz Stern quoted in Sternhill, "Fascist Ideology," 361. Roger Griffin, Modernism and Fascism: The Sense of Beginning under Mussolini and Hitler (New York: Palgrave Macmillan, 2007), 223, 241.
} 
economic sphere (which is debatable), it was revolutionary in their conception of the state and individual loyalties. They promised rapid technological advances, unprecedented military power, and cultivated a style that was far from traditional. A relatively unimportant but telling difference between the two groups can be seen in their attitude towards modern advances in transportation. While for many fundamentalists the automobile and airplane were seen as harmful and prophetic fulfillments of an increased capacity for mayhem, Fascists embraced fast cars and airplanes as tools to master in the brave new age that they intended to dominate. More generally, dispensationalists were watching an evil world rush onward to its destruction, while Fascists were lionizing action in the service of bringing about an ill-defined but glorious future. $^{208}$

\section{Mussolini, Man of Mystery!}

If Fascism's anti-Christian elements, sacralized ideology, and version of modernity all reinforced the case for Mussolini as the Antichrist, the cult of personality that he and the Fascists cultivated made his candidacy even more plausible. It not only served as an obvious example of false religion similar to what was expected out of the Antichrist, but dispensationalists seemed to take some of the cult's claims at face value. While Mussolini's geographic context, political and economic power, ideology, atheistic biography, and as we will see, relationship with Catholicism, already combined to make a compelling case for dispensationalists that he might be the one, many of them cited what they perceived to be his singular personality. Obviously, the Antichrist would be unique. Dispensationalists believed, along with John, there were many antichrists and the spirit of the antichrist had existed for millennia, but there would be one Antichrist with unprecedented power and several characteristics described in the Bible. Arthur

\footnotetext{
${ }^{208}$ Sternhill, "Fascist Ideology," 342.
} 
Pink provided Biblical citations to show that the Antichrist would be an intellectual, oratorical, political, commercial, military, governmental, and religious "genius." Mussolini claimed expertise in most, if not all, of these areas. ${ }^{209}$

The perception that there was something unique about Mussolini was something he and his Fascist regime cultivated from the beginning. Despite all the various intellectual currents that fed in to the founding of Fascism, Emilio Gentile argues that "the distinctive cornerstone and basic element of fascist ideology" became the role of the "leader" to rally, discipline, and transform the masses. As time passed, Fascism generally and Mussolini specifically consolidated power and the competing ideologies became secondary to the primacy of Il Duce. In fact, once his power became secure Mussolini discouraged factional disputes within Fascism, preferring an undifferentiated front that would facilitate his real goal: maintaining an iron grip on power. Whether we interpret this emphasis on the "leader" as retrospectively transparent selfinterest or with Gentile interpret it as a genuine ideological position influenced by Nietzsche and Gustave LeBon's The Crowd, it resulted in the development of an effective personality cult. ${ }^{210}$ After he took power, Mussolini used every medium he had at his disposal to foster the image of the charismatic, omnicompetent leader. Each of the Fascist Party secretaries played a big role in implementing new rituals to reinforce this impression, reaching ridiculous proportions during the tenure of Achille Starace (1931-1939). The cult's propagation accelerated in 1925 as remaining forces of opposition were purged, and it was "institutionally embedded in the Fascist

\footnotetext{
209 Pink, The Antichrist, 77-83.

${ }^{210}$ Gentile, Origins of Fascist Ideology, 344-351.
} 
state" by 1926. The effectiveness of this propaganda seems to have peaked between the signing of the Lateran Accords in 1929 and the aftermath of the Ethiopian invasion in $1936 .{ }^{211}$

One method that Mussolini used to foster this infallible image was by authorizing several biographies, which constructed what R.J.B. Bosworth calls the "imagined Mussolinis." Several of these were translated into English, meaning they had the potential to not only shape Italian perceptions, but American ones. Maybe the most important was The Life of Mussolini (1925) written by his long-time mistress and leading art critic Margherita Sarfatti. The English edition actually preceded the Italian one and helped spread the Mussolini myth beyond Italy's borders. To call this work a hagiography would be an understatement. Sarfatti made no effort at journalistic accuracy and had no problem admitting that her intention was "[t]o create a legend." The book contains most of the themes that would become ubiquitous in Mussolini's depictions in the years to come. This included the focus on the Duce's body as a tangible representation of his dynamic personality and the ideal representation of the Roman essence. His leadership abilities were depicted as almost supernatural, his personality as charismatic, enigmatic, paradoxical, energetic, ambitious, action-oriented, but yet somehow "a man of the people" who encapsulated the Italian population. Sarfatti claimed he was "[i]mpulsive and meditative, a realist and an idealist, perfervid and yet wise, a romantic in his aspirations but a classic in his handling of practical affairs" but with "a groundwork of consistency in him underlying all these seeming incompatibilities." She relished in anecdotes illustrating his physical courage, claiming "the very idea of cowardice revolts him." These themes persisted throughout Mussolini's rule and Giorgio Pini’s 1939 official biography included an even broader range of fields that Mussolini excelled

\footnotetext{
${ }^{211}$ Stephen Gundle, Christoper Duggan, and Guiliana Pieri, "Introduction," and Christopher Duggan, "The Propagation of the Cult of the Duce," in The Cult of the Duce, ed. Stephen Gundle, Christopher Duggan, and Guiliana Pieri (Manchester, UK: Manchester University Press, 2013), 2, 34, 39.
} 
in. Not only do we learn that his "subtle instinct enables him to estimate the imponderable elements of the various situations and gives him a presentiment of the future," but we also find that "his muscular tension is as constant as his mind" and learn of his naturally dexterous movements "driving a car, a speedboat or a motor-cycle, on his guard in fencing, piloting an aeroplane, ski-ing, his bare torso exposed." Mussolini anticipated the pictures found in Vladimir Putin's hunky, often shirtless calendars by several decades, with photos of him frolicking with his favorite lioness at the zoo, others showing him stripped to the waist while threshing the grain among peasants or striding through waves at the beach. These perceptions informed almost every form of mass media in Fascist Italy, including the architecture of Rome. ${ }^{212}$

This blatant self-aggrandizement seems ridiculous with the benefit of hindsight and it strains credulity that intelligent, moral people could be taken in by it. But this probably says more about the difficulty of inhabiting the viewpoint of people in the past than it does about their mental disposition. For admiration of Mussolini or at least some of his qualities was not limited to reactionary rubes or simple-minded fundamentalists. Especially in the first decade of his rule Mussolini enjoyed a great deal of popularity outside Italy, including in the United States. Many Americans admired Mussolini without reservations, others who were more uncomfortable about his intentions found things to respect, and even some who disliked him found him unique.

Several of the images his biographers presented were adopted by American observers, including the "spiritual savior" who rescued his people from communism and materialism, the "pragmatic

\footnotetext{
212 Bosworth, Italian Dictatorship, 61; Simona Storchi, "Margherita Sarfatti and the Invention of the Duce," in The Cult of the Duce, ed. Stephen Gundle, Christopher Duggan, and Guiliana Pieri (Manchester, UK: Manchester University Press, 2013), 41-54; Margherita G. Sarfatti, The Life of Benito Mussolini, trans. Frederic Whyte (New York: Frederick A. Stokes, 1926), 342; Giorgio Pini, The Official Life of Benito Mussolini, trans. Luigi Vilarri (London: Hutchison and Co., 1939), 222-223,228; Pooley, "Mussolini and the City of Rome," 209.
} 
statesman," the "hero of sport," the "man of action," a "self-made man," and even "the great lover." 213

Dispensationalists were not completely dissimilar to other Americans when it came to how they perceived Mussolini. Like Americans more generally, there was often a mixture of concern and admiration, with some variation within the group regarding the balance of those emotions. Of course, the main difference was that dispensationalists saw his traits through an eschatological filter, more specifically in light of what their reading of scripture led them to expect from the Antichrist.

Mussolini's arrogance and boasting fit their expectations for a world dictator with the temerity to demand worship. His exaltation of violence and force was also consistent with the king mentioned in Daniel who will "honor the god of fortresses" that dispensationalists believed represented the Antichrist. Louis Talbot compared those Biblical passages with quotes from Mussolini's speeches that called for soldiers with "a more aggressive spirit" whose "ruling passion is combat." Again, Mussolini's characteristics not only fit in with scriptural expectations of coming violence and strife, but his violent spirit reflected dispensationalist concerns with increasing crime rates domestically and fears of war internationally, both very common themes in their magazines, especially in the ubiquitous lists of reasons to believe that the end was near. $^{214}$

Arrogance, blasphemy, and violence may not have made for such a convincing case if Mussolini was perceived as a fool. Dispensationalists believed the Antichrist would be a powerful and clever manipulator. But dispensationalists seemed genuinely impressed by

\footnotetext{
${ }^{213}$ Diggins, Mussolini and Fascism, 24, 58-73.

214 Talbot, Coming World Dictator, 8; Louis S. Bauman, There Shall Be Signs, King's Business, March 1931, 101-102; Unknown, Editor's Notebook, Pentecostal Evangel, September 13, 1930, 4.
} 
Mussolini's perceived competence and charisma. This was especially true in the 1920s when the perception that he could be the Antichrist was being formed. A 1925 Pentecostal Evangel article listing all "the most noteworthy developments in the signs of the times" had a heading simply titled "Mussolini" along with many other ominous indicators like "Centralization" and "Women Behave as Men." It said he was "the strongest character in world politics today." The author of a 1926 article that thought "Rome was crammed with apocalyptic atmosphere" claimed that Mussolini was "the only great surviving personality" to emerge from the wake of the Great World War. ${ }^{215}$

Bauman, who was probably the most consistent and prominent advocate for Mussolini as the Antichrist, called him a "strange and wonderful character." He made much of Mussolini's supposed mysteriousness, citing newspaper articles that called him "a man of mystery" and pointing out that the scarlet harlot in Revelation will have "mystery" written on her head and the "man of sin" in Second Thessalonians is associated with "the mystery of lawlessness." Mary Winey Morris thought his meteoric rise to power was mysterious and called him a "gigantic genius." A book reviewer in The King's Business said his accomplishments were "almost unbelievable." Some dispensationalists would become less impressed by the late 1930s but several continued to be awestruck. After describing the order and "marvelous transformation" of Italy, W.D. Herrstrom called Mussolini a "superstrategist" in 1937 and claimed that when he speaks "Europe trembles and the League of Nations cowers with fear." 216

\footnotetext{
${ }^{215}$ A.H. Argue, "Perilous Times-A Survey," Pentecostal Evangel, February 7, 1925, 6.; Unknown, "Resurrection of the Roman Empire" 2, 7.

${ }^{216}$ Bauman, "Antichrist at Hand," 15; Bauman, "Marks of the Antichrist," 75; Rev. 17:5 (KJV); 2 Thess. 2:7 (KJV). Morris, Prophecy, 92; Unknown, Our Literature Table, King's Business, September 1928, 566; W.D. Herrstrom, "The Resurrection of an Empire," King's Business, September 1937, 336.
} 
Sometimes the way they expressed their fascination with both Mussolini and Fascism crossed into admiration. Even as Mussolini seemed to embody some of their greatest threats he also served as a misguided but intriguingly effective response for some of their concerns. Dispensationalist magazines were rife with warnings about the increasing lawlessness and immorality in the United States and it was hard for them not to admire a leader who did not tolerate disorder. Oswald Smith approved of his "[r]eal leadership" that "saved Italy." Mrs. Gilbert Potter's 1923 dispatch from Rome published in the MBIM was one of the earliest articles that hinted at a link between Mussolini and prophecy. A good part of her article focused on Mussolini's success in creating a well-ordered society. Although she thought he would eventually team up with the Vatican to inhibit religious liberty she was obviously impressed with what she called an "ethical awakening" and approvingly told of a young Fascist who restrained from checking out "a rather questionable, showy woman" because of his commitment to Mussolini and Fascism. Two missionaries that were granted an interview with Mussolini (and informed him of their suspicions that his revival of Rome was predicted in prophecy) were extremely complimentary in their article on the encounter, fawning not only over "the order and cleanliness and courtesy" of Mussolini's Italy but also over his "remarkable physiognomy" that included a "jaw of almost incredible proportions" expressing his "driving power, iron discipline, and inflexible will. ${ }^{217}$

When dispensationalists were doubtful that he would be the Antichrist, this admiration could become less ambiguous. The friction that was sometimes manifested between Mussolini and Catholicism was one source of respect. In 1934 an editor of MBIM was so impressed with the English translation of Mussolini's book on the proto-Protestant martyr John Huss that he

\footnotetext{
${ }^{217}$ Smith, When Antichrist Reigns, 38; Potter, "Will Mussolini and the Pope Join Forces," 110; Ralph C. Norton and Edith F. Norton, "A Personal Interview with Mussolini," Sunday School Times, August 13, 1932, 432.
} 
claimed it would convince readers that Mussolini was not the Antichrist, "as some thoughtlessly imagine." While he acknowledged Fascism could have a role in setting the stage for the Antichrist, he argued that Mussolini's version of it protected Italy from the evils of "Vaticanism and Communism," and for the time being Christians ought "to wish it success." 18

Dispensationalists also were not immune to the eugenic fears of the time and could be attracted to Mussolini's racist pronouncements. Arno C. Gaebelin did not believe Mussolini was the Antichrist and so made no effort to restrain his admiration. Gaebelin's staunch anticommunism made him predisposed to admire Mussolini and he left hints in his writing that he had problems with interracial contact. We saw above that he implied that the role African Americans had in the early Pentecostalism was discrediting and he also told in his autobiography of preaching in a southern church where blacks had to ask to attend and were only allowed in the gallery. This observation was made without any censure of the hosting church's segregationist policies, but he did mention how excited his talk made the black attendees. He made his racial anxiety more explicit when he approvingly quoted Mussolini's warnings that white America's declining birth rates combined with the "extraordinary fecundity" of American blacks would result in an "Africanized America" and even "within a century a negro in the White House." He also cited Mussolini's Huss biography and claimed "[h]is love for the Bible is well-known." Gaebelin called Mussolini a "great statesman" and "benefactor to his native land." His unabashed appropriation of Mussolini in support of his own issues was rare, but even those most convinced of the evil role he would play were often impressed with his accomplishments and personal traits, especially when they thought he effectively dealt with concerns they shared. ${ }^{219}$

\footnotetext{
${ }^{218}$ Unknown, Editorial Notes, Moody Bible Institute Monthly, February 1934, 252.

${ }^{219}$ Gaebelin, Half a Century, 187-188; Arno C. Gaebelin, “Listen, America, To Mussolini," Our Hope, June 1934, 739740.
} 
Dispensationalists also were vigilant about finding relatively obscure connections between prophecy or other foreshadowing in the scripture and what they observed with Mussolini. For example, dispensationalists watched closely for any news that statues were being built to honor him. Articles on Mussolini statues started appearing in their magazines as early as 1928. When news got out in the mid-1930s that the Fascists were planning a massive statue, the Colossus of Fascism, dispensationalists immediately saw its prophetic importance. It was only the latest attempt to "materialize aspects of the cult in the cityscape" but given it was designed to be 86 meters tall and visible from everywhere in Rome, it attracted even more attention from dispensationalists than usual. Its features would resemble the Duce's, creating "a sublimated and deified ideal" of the great leader. The colossus was never built, likely due to scarce funds and more pressing concerns as the next world war loomed. Rumors of this statue made dispensationalists think of both the great statue built by Nebuchadnezzar in the book of Daniel and the image that the beast would build, according to Revelation. Dispensationalists thought Nebuchadnezzar's "image" was a precursor to the beast's, as they both were meant for worship. Even if the Colossus of Fascism did not prove to be the image of the beast it was certainly part of the trend to prepare the world "for great, awe-inspiring images." 220

Given dispensationalist understandings of the Antichrist, Mussolini and his regime's combination of statolatry, personality cult, concentration of political and economic power, aggressive military ambitions, and geographic position seemed to add up to a viable candidacy to be the government of the prophesied "man of sin." But if those considerations were not enough, Mussolini had a complicated relationship with a long-standing source of prophetic speculation,

\footnotetext{
${ }^{220}$ See Unknown, "Giant Monument for Mussolini," Pentecostal Evangel, September 29, 1928, 5; Pooley, "Mussolini and the City of Rome," 209, 219-220; Trumbull, Prophecy's Light on Today, 98; Relevant Bible verses include Daniel 3:1-7 and Revelation 13: 14, 15.
} 
the Catholic Church. Not only did his interactions fit their expectations, but Catholicism's role in American society was one of the most important issues for fundamentalists during the interwar period.

\section{The Great Harlot}

Ever since the Protestant Reformation, Catholicism and the Pope have been expected by some Protestants to play a malevolent role in end-times prophecy. Dispensationalists were not only heirs to this tradition but were living in a time of American Protestant concern with the greater public role played by a growing Catholic population. Although this is one of the few issues that they were in agreement with their more liberal Protestant counterparts, fundamentalists were some of the most virulent anti-Catholic voices of the time. Opposition to Catholicism was important enough of an issue to merit space in The Fundamentals. There, T.W. Medhurst claimed Catholicism was not only in error, it is "so different from, and so hostile to, real Christianity, that it is not, in fact Christianity at all.” It not only was not Christian, much like socialism Catholicism had ancient, demonic origins. Louis Talbot traced Catholicism back to the "mystery religion" established by Nimrod and the founding of Babel (later Babylon), the same Biblical figure who we saw earlier was associated with the origins of socialism. When Constantine converted he actually was blending Christianity with that already ancient mystery religion, meaning that the Papacy was "not a successor to Simon Peter, but is rather the successor to the high priest of the heathen mysteries that began way back there in Babel." The influence of this Satanic counterfeit was present in all false religions, but Catholicism has been its most “conspicuous exemplification" since Rome's adoption in the fourth century. ${ }^{221}$

\footnotetext{
${ }^{221}$ T.W. Medhurst, "Is Romanism Christianity," The Fundamentals, reprinted in Barry Hankins, ed. Evangelicalism and Fundamentalism: A Documentary Reader (New York: New York University Press, 2008), 218; Louis Talbot, The Scarlet Woman (Los Angeles: Talbot Publications, n.d.), 14; Keith L. Brooks, Prophecy and the Tottering Nations (Los Angeles: Brooks, 1935), 18.
} 
Dispensationalists purported to respect the right of Catholics to worship as they pleased but believed that the Papacy wanted to exert global political control, therefore they were suspicious of Catholic loyalties and saw their proselytization as extremely dangerous. Competition from Catholics, both domestically and in foreign mission fields, was also part of their concern. $M B M I$ even blamed Catholicism's aggressive tactics and unwillingness to be fully American for the activities of the Ku Klux Klan. Dispensationalist publications were full of complaints regarding the "rancorous Romanists" that were competing in the mission field and in predominantly Catholic countries, oppressing Protestant missionaries and their converts. Even before Mussolini's rise, Catholicism was linked to many contemporary issues of concern, including the "liquor element," wider nativist fears, and the perceived laxity of mainline Protestantism. The Papacy was associated with Kaiser Wilhelm, accused of orchestrating World War I, accused of bribing President Woodrow Wilson, and suspected of dominating the League of Nations. $^{222}$

Catholics were an ever-present target in dispensationalist periodicals, but anxiety reached a peak when Al Smith won the 1928 Democratic nomination for President. Smith was a "wet," which was bad enough, but what really concerned dispensationalists and many other Protestants was the suspicion that as a Catholic he had divided loyalties. Their periodicals closely followed the race and the widespread debate over whether a Catholic President was acceptable. For the editors of the $M B I M$ the question was not "one of personal religious freedom, but one of the

\footnotetext{
222 Unknown, Editorial Notes, Moody Bible Institute Monthly, September 1924, 3; William H. Hockman, Missionary Department, Moody Bible Institute Monthly, September 1928, 24; Unknown, "Rum and Romanism," King's Business, October 1917,873; Hankins, God's Rascal, 53-54; Unknown, Editorial Notes, Moody Bible Institute Monthly, August 1926, 555; Unknown, "The Pope and the Kaiser," King's Business, January 1918, 5-7; R.A. Torey, "Rome Behind the Great War," King's Business, June 1919, 574-575; Unknown, "Wilson's \$40,000 Handout from the Pope," King's Business, June 1919, 498; W.H.P., "Will Rome Again Dominate the World," King's Business, September 1919, 299-300.
} 
control of the government by an alien power." Therefore, William Taft's presidency was not anywhere near as problematic as a hypothetical Smith presidency would be, despite the greater degree of heterodoxy found in Taft's Unitarian religious affiliation. Many prominent fundamentalist preachers openly campaigned against Smith, including New Yorker John Roach Straton in the North and Frank Norris in the South. Norris's rhetoric illustrates the various issues that were associated with the Smith candidacy in the South. He warned a Smith victory would result in an invasion of "the dregs of Southern Europe," lumped together "Tammany Hall, Roman Catholicism, bootleggers, carpet bag politicians and negros," and called on "red-blooded white folks...who love God, who love the flag, and who love order" to stand up to "the lowdown whiskey-soaked imps of hell.".223

Frank Norris was tireless in his criticism of Catholicism, especially the Catholic politicians of his Forth Worth home. In the summer of 1926 he accused the Catholic mayor of conspiring with a Catholic school to overvalue some of their property that the city government would need to build a street. When one of the mayor's prominent (and unarmed) Catholic supporters confronted Norris in his office, Norris shot him dead. The details of the incident were murky, but in January 1927 the jury agreed with Norris that the shooting was an act of selfdefense and acquitted him, which pleased the editors of MBIM. ${ }^{224}$

The tone at Moody Bible's house organ was actually more measured than some of the more flamboyant fundamentalists, even though they opposed Smith's candidacy. Some of their readers thought that when they expressed admiration for Smith personally they were compromising their stand, and despite constant coverage and consistent opposition to his

\footnotetext{
${ }^{223}$ Unknown, Editorial Notes, Moody Bible Institute Monthly, September 1927, 4; Barry Hankins, Jesus and Gin (New York: Palgrave Macmillan, 2010), 201-202.

${ }^{224}$ Hankins, God's Rascal, 118-120; See Editorial Notes, Moody Bible Institute Monthly, March 1927, 324;
} 
candidacy, readers exhorted them to "speak out" more. The sense of cosmic import was felt across all dispensationalist factions, as The Pentecostal Evangel called the 1928 election "the greatest crisis since the Civil War" with implications that as "a struggle between the powers of light and darkness," much more was at stake than mere earthly political policies. As it turned out, Herbert Hoover won, and a Pope-controlled American executive branch was averted. But the perceived Catholic menace would remain, especially among dispensationalists. The religious xenophobia of the broader Protestant population was intensified by their interpretations of Biblical prophecy. ${ }^{225}$

Dispensationalists interpreted verses in Revelation that refer to a "great harlot," "arrayed in purple and scarlet" as symbolizing the Catholic Church and what they saw as its apostate form of Christianity. This harlot is depicted riding the beast and "drunk on the blood of the saints" until the beast turns on her, eating and burning her flesh. They interpreted this to mean that Catholicism would be aligned with the Roman ruler for a time, even exerting influence over his policies, until the Antichrist reverses course and then destroys it. If such an alignment transpired, it would be a clear sign that prophecy was rapidly moving toward fulfillment. ${ }^{226}$

From the beginning of their speculations about Mussolini, dispensationalists watched his relationship with the Vatican closely and it is not difficult to see how they could fit their observations with their interpretation of scripture. Despite his long, published record of anticlericalism, Mussolini began to change direction around 1920. At the second Fascist congress he acknowledged the power of the Vatican and the possibility of using it to facilitate the advance of the nation. Once in power the relationship between Mussolini and the Church was wary but

\footnotetext{
225 Unknown, Editorial Notes, Moody Bible institute Monthly, November 1928, 101; Unknown, “A Day of Prayer for America's Crisis," Pentecostal Evangel, September 29, 1928, 5.

${ }^{226} \operatorname{Rev}$ 17:1-18 (KJV); Talbot, The Scarlet Woman, 3-7; Arthur I. Brown, I Will Come Again (Findlay, OH:

Fundamental Truth, 1947), 84-85.
} 
cooperative, with many twists and turns. It was obvious that the various accommodations made by Mussolini and the Catholic Church towards each other were self-interested and tenuous. Early in the relationship Pope Pius XI referred to Mussolini as he "whom providence has sent us" but Pius XI also admitted that he would "make a concordant with the devil if it benefited the Church." 227

In 1929 Mussolini and Pius XI signed the Lateran Accords, which granted sovereignty to Vatican City, established its boundaries, affirmed that Catholicism was the sole religion of the Italian state, resolved the Church's economic claims for the loss of the Papal States, and addressed a variety of civil issues, including marriage, education, and voluntary organizations. The agreement was the result of pragmatic decisions made by both sides. Emma Fattorini claims that Mussolini saw religion as a necessary instrument while the Catholic Church saw Mussolini as a vehicle to regain a "leading role" for the Church in society that had been in jeopardy since the French Revolution. But "reciprocal expectations" resulted in "reciprocal manipulations" with Mussolini attempting to "fascitize the Church" while Pope Pius XI "sought to Catholicize fascism." Bosworth thinks that Pius XI was at least as ambitious as Mussolini was in advancing the fortunes of his organization and that this "uneasy relationship" is best understood "as a meeting between a long-sighted Church and a short-sighted regime." The pragmatic nature of this relationship was recognized by many at the time and the journalist George Seldes, who was a frequent critic of Mussolini, described the agreement as "a magnificent example of political

\footnotetext{
${ }^{227}$ R.J.B. Bosworth, Mussolini, (London: Bloomsbury Academic, 2010), 117; Emma Fattorini, Hitler, Mussolini, and the Vatican: Pope Pius XI and the Speech That was Never Made, trans. Carl Ipsen (Malden, MA: Polity Press, 2011), $1,8$.
} 
opportunism" but argued that the two sides "cannot exist forever, morally function, side by side. ${ }^{228}$

Dispensationalists were watching the interested but wary interactions between these two totalizing ideologies almost immediately after Mussolini took power, long before the historic Lateran Accords of 1929. In 1923, one of the first articles to appear in MBIM addressing Mussolini was entitled "Will Mussolini and the Pope Join Forces?" In 1926 The Pentecostal Evangel thought their ambivalent relationship was lining up perfectly with what students of prophecy expected: "a close but embarrassed alliance," pagan empire and "church, awkwardly housed under the same roof." Referring to Revelation's portrayal of the scarlet woman sitting on the beast, in 1926 Bauman claimed the Vatican had its "foot in the stirrup" and that "the 'woman' is about to mount the 'beast!'” In 1929 Mussolini and the Pope signed the Lateran Accords and by 1931 Bauman claimed that "the marvelously bedecked harlot" was riding. Bauman thought that Mussolini's past evidence of anti-Christianity combined with his accommodation to the church fit the part perfectly. He and many other dispensationalists expected a close relationship where Mussolini would use the church for his own benefit, but that would end with Mussolini showing his true colors in a violent betrayal. As the Vatican leapt into the saddle she was "vaulting to her doom." Fascism was using "a screen of religious patronage to hide its real purposes as an aspirant for world domination. ${ }^{229}$

\footnotetext{
${ }^{228}$ David I. Kertzer, The Pope and Mussolini (New York: Random House, 2014), 106-107; Fattorini, Hitler, Mussolini, and the Vatican, x-xi; Bosworth, Italian Dictatorship, 144-145; George Seldes, Sawdust Caesar (New York: Harper and Brothers, 1935), 258-260.

${ }^{229}$ Potter, "Will Mussolini and the Pope Join Forces," 110; Unknown, "The Resurrection of the Roman Empire," Pentecostal Evangel, October 9, 1926, 2; Louis T. Bauman, "Is the Antichrist at Hand? What of Mussolini," King's Business, January 1926, 16, 42; Louis T. Bauman, Present-day Fulfillment of Prophecy, King's Business, September 1931, 390; Unknown, "Resurrection of the Roman Empire," 2; Louis Richard Patmont, The Mystery of Iniquity:An Expose of the Spirit and Nature of International Communism (Fresno, CA: Graeter Publishing Concern, 1933), 47.
} 
Dispensationalists believed that the partnership between Catholicism and Fascism was not only prophesied to end treacherously but agreed with secular critics like Seldes that the nature of both ideologies demanded total allegiance, meaning the relationship was doomed even using merely this-worldly logic. Nicholos Pirolo, an Italian-American dispensationalist evangelist who wrote a book on the topic of Mussolini and the Catholic Church in 1937, claimed that Mussolini would not be satisfied with political control and that Fascism "seeks to reign religiously," while "Popes have always wanted to rule politically." The coming clash prophesied in Revelation was inevitable. Whatever the merits of dispensationalist prophetic interpretation there was ample evidence to support their more earthly claims. Fattorini claimed that as long as Fascism served as a "civil religion" excessive friction was avoidable but when it became a "true political religion" that tried to "penetrate consciousness and control individual subjectivity" a collision was inevitable. ${ }^{230}$

Within a month of signing the Lateran Accords it became obvious that each side interpreted the issue of "sovereignty" differently. Mussolini argued in two speeches during May of that year that the part of the treaty referencing a "free and sovereign Church; a free and sovereign state" did not imply "two coexistent authorities." Rather "within the state, the Church is neither sovereign or free." Pope Pius XI responded immediately, arguing that the Concordant meant that the Fascist state could "not allow anything that is not in accordance with Catholic thought and doctrine."231

Obviously both entities saw their spheres as overlapping and taking precedence over the other. Mussolini had appropriated the term "totalitarian" from some of his early critics and

\footnotetext{
${ }^{230}$ Nicholas Pirolo, Babylon, Political and Ecclesiastical Showing Characteristics of the Anti-Christ and False Prophet Considering Mussolini and the Pope (Milwaukee: Word and Witness, 1937) 94-96; Fattorini, Hitler, Mussolini, and the Vatican, xi. See footnote 117 regarding the way these terms are being used differently from Gentile.

${ }^{231}$ Fattorini, Hitler, Mussolini, and the Vatican, 38.
} 
proudly applied it to his regime, famously stating "all is for the state, nothing is outside the state, nothing and no one are against the state." He claimed a sphere of dominance for Fascism that went well beyond the purview of liberal democracy, including areas that were important to the Church, like education and "spiritual life." As the relationship soured in the late 1930's Pope Pius XI illustrated the accuracy of dispensationalist analysis when he told a group of French Catholic workers that "if there is a totalitarian regime - totalitarian by facts and by rights - it is the regime of the Church" and only the Church "has the right and obligation to lay claim to the totality of its power over individuals." ${ }^{232}$

Upon Pius XI's 1939 death, Pius XII adopted a more conciliatory posture with the Fascist government and strengthened the uneasy alliance. The cooperation and conflict expected between the Catholic Church and the Roman ruler led to a curious situation where examples of either friction or harmony could be cited as evidence as long as there was not a complete break in the relationship before the rapture arrived. Bauman once cited news about acrimony between the two as a prophetic sign in his column, only to cite examples of their cooperation as evidence in the following month's issue. ${ }^{233}$

Besides reviving imperial Rome, Mussolini's relationship with the Catholic Church was the topic most commonly remarked on by dispensationalist authors. There was an almost perfect alignment between eschatological tradition, contemporary American concerns, and the ambivalent nature of his interactions with Rome, to incite dispensationalist speculation. Another area where Mussolini's ambivalence actually worked to fuel prophetic speculations was in how he related to Judaism.

\footnotetext{
232 R.J.B. Bosworth, Mussolini's Italy (New York: Penguin Press, 2006), 215. Mussolini, Fascism, 13; Fattorini, Hitler, Mussolini, and the Vatican, 169.

${ }^{233}$ Louis T. Bauman, Present-day Fulfillment of Prophecy, King's Business, August 1931, 341; Louis T. Bauman, Present-day Fulfillment of Prophecy, King's Business, September 1931, 389-390.
} 


\section{Mussolini, Jewish Fascist?}

Premillennial dispensationalists have a complicated relationship with Judaism. This is partly due to the persistence of anti-Semitic stereotypes that they inherited from the wider Christian tradition, but their views are also shaped by an eschatology that places Israel and the Jewish people in a particularly prominent place. The details vary but a standard timeline was shared by most interwar dispensationalists. They believed that the Jewish people would return to Palestine and rebuild the Temple by the beginning of the seven-year Tribulation period. Somehow the Antichrist would become their leader as a false messiah. Three and one-half years into the Tribulation the Antichrist will turn on the Jews and demand worship. A godly remnant will refuse and cry out to God, resulting in horrible persecution at the hands of the beast. At the end of the seven years Christ will return and destroy the Antichrist before Israel is completely annihilated. ${ }^{234}$

Dispensationalists agreed on the general outline of the expected events but there were a range of attitudes towards Jews. This is much less common today, but during the interwar period there were still dispensationalists with strong anti-Semitic tendencies. At the same time, there were prominent preachers who expressed a philo-Semitism that was similar to more current tendencies among Christian Zionists. Maybe most common was a position somewhere between these two poles, a mixture of admiration and respect for that godly remnant of the chosen people along with a suspicion of the majority of Jews that they saw as rejecting Christ and involved with a number of anti-Christian movements. Gerald Winrod was on the anti-Semitic end of the spectrum, enough so that he became less welcome in dispensationalist circles by the 1930s. That being said, even he exhibited some of this ambivalence. He consistently denied he was anti-

\footnotetext{
${ }^{234}$ See Louis T. Bauman, “False Christs and False Prophets....a Sign,” King's Business, August 1934, 308.
} 
Semitic, supporting this claim by distinguishing between good Jews and those involved in the global conspiracies that he bought into. He argued that members of the lost tribe of Dan were actually the Jews who were causing the problems. He claimed to have nothing against other Jews. This conveniently allowed him to rail against all the nefarious Jewish (Danite) activities going on while believing that he was not opposing God's chosen people. Leo Ribuffo points out that even as Winrod's dispensationalist beliefs partly explained his anti-Semitism, those same beliefs limited how far it could go. Winrod believed in the veracity of the Protocols of the Elders of Zion but claimed to reject oppression of Jews based on "race or religion." On the other end of the spectrum was Louis Bauman, who while describing the Jewish remnant that would refuse to worship the beast in the face of unimaginable persecution, could not help but exclaim "[n]o wonder Jehovah loves the Jews!" Often dispensationalists emphasized the chosenness and coming blessing for the Jewish people, even as they explained their historical sufferings as a result of their disobedience. Apparent attempts at complimentary generalizations often were uncomfortably similar to common negative stereotypes. In his aptly named The Remarkable Jew, Leonard Sale-Harrison said they are no more questionable in their business tactics than their Gentile counterparts, but he called them "wizards of finance" with "wonderful keenness in business matters," enjoying remarkable "control" over numerous industries. Concerns about Judaism were linked to the anti-Semitic tropes relevant to other issues prominently on the minds of dispensationalists like the polluting influences of the movie industry, the Red Scare, and nativist concerns, so Jewish issues were salient for both eschatological and non-eschatological reasons. ${ }^{235}$

\footnotetext{
${ }^{235}$ Ribuffo, Old Religious Right, 114; Bauman, Light from Bible Prophecy, 166; L. Sale-Harrison, The Remarkable Jew: His Wonderful Future, God's Great Timepiece (New York: Sale-Harrison, 1934), 54-55.
} 
Italian Fascism was actually one of the least anti-Semitic of the fascist variants, at least until 1938. This relative friendliness to Jews worked to the favor of Mussolini's candidacy, especially given all of the other fitting characteristics he possessed. Dispensationalists reasoned that if the Antichrist was to be accepted by Israel as its leader and protector it would not make sense for him to be a blatant, anti-Semitic maniac like Hitler. But Mussolini, the anti-clericalist who shrewdly contained his anti-Christian tendencies, seemed to fit the mold of the cunning beast who would deceive the Jewish people, only to turn on them in fury when they resisted his demands for worship. Dispensationalists often contrasted and reported Mussolini's friendliness to Jews with Hitler's persecution, like his role in founding a Chair of Romance Languages at Hebrew University and his appointments of Jews to high political offices. Mussolini at times seemed sympathetic to the establishment of a Jewish state in Palestine, which also fit nicely into dispensationalist prophetic scenarios. They explicitly tied these positive relations to the Antichrist. When Mussolini's alliance with Hitler in 1938 suddenly moved Italy's policies in a more racialist and anti-Semitic direction this became problematic. But this was late in the period, and as we will see below, Mussolini's star was beginning to fade in a variety of ways, including his candidacy for the Antichrist. Bauman, Mussolini's staunchest advocate, argued that Italy had little zeal for their new anti-Semitic programs and that he was merely posing as a "Jew-baiter" in order to utilize Hitler to weaken France and England. ${ }^{236}$

The congruence between Mussolini and their prophetic interpretations was not always perfect, but there was enough flexibility built into the dispensationalist system and more secular interpretations that this was not usually too big of an obstacle. One contested but not uncommon

\footnotetext{
${ }^{236}$ Thomas M. Chalmers, “The Present Situation in World Jewry, King's Business, June 1934, 217; Arthur U. Michelson, The Jews and Palestine in Light of Prophecy (Los Angeles: Jewish Hope Publishing House, n.d.), 73; Bauman, Light From Bible Prophecy, 156-157.
} 
dispensationalist belief about the Antichrist that cast some doubt on Mussolini's candidacy was that he would be Jewish. This belief was mostly based on the fact that when Daniel described the "willful king" that many dispensationalists equated with the Antichrist, he said "[n]either will he regard the God of his fathers, nor the desire of women." Dispensationalists have drawn a variety of conclusions from this verse, but some saw the "God of his fathers" as a uniquely Jewish formulation that implied the Antichrist would be a Jew that rejects the Jewish God. The “desire of women" passage also had many interpretations, but some argued that this was referring to the desire of Jewish women to be chosen to bear the Messiah. Some dispensationalists also reasoned that if the Antichrist was going to pass himself off as a false Messiah he would have to be a Jew himself. ${ }^{237}$

This could easily be dealt with since a Jewish heritage for Mussolini could not be disproven. The intensely anti-Semitic Gerald Winrod, who believed that the lost Israelite tribe of Dan was responsible for much of the world's mischief, including Communism and Fascism, suspected that Mussolini's ancestors were from this nefarious group, meaning he met the Jewish requirement and "may be a party to the age-old plot to enslave the Gentiles of the world." He mentioned rumors of a Jewish background and thought it was significant that Mussolini's daughter's husband was close to the Rothschilds. Using another strategy, an article in MBIM argued that the Roman ruler described in Revelation was a distinct figure from the Jewish Antichrist, even though many dispensationalists saw them as the same person. While the Jewish figure was identified as the Antichrist, the author claimed there was a "distinct advantage in this position" in that Mussolini could still be the "man of sin" that immediately preceded the Antichrist's emergence and Christians could still rejoice that the end was near. Apparently at

\footnotetext{
${ }^{237}$ Dan. 11:37 (KJV); Talbot, Coming World Dictator, 7.; Bauman, “Marks of the Antichrist," 76.
} 
least part of the motivation for this unique interpretation was to somehow fit Mussolini in the picture..$^{238}$

Dispensationalists during the interwar period believed that Satan was the originator of all types of competing ideologies that directly contradicted or subtly undermined their understanding of Christianity. Given the ways that many of these ideologies could be plausibly connected to Mussolini reinforced the likelihood that he was either a precursor of the Antichrist or that dreaded figure. Even setting aside their eschatological beliefs, many of these ideologies were threatening to dispensationalists and their vision of an ideal society. This combination of threatening social trends and seeming eschatological fit magnified their interest in end-time speculation, especially in the man who had revived the Roman Empire.

${ }^{238}$ Winrod, Writings, 24-25; Robert T. Ketcham, "The Man of Sin not the Antichrist," Moody Bible Institute Monthly, August 1933, 535. 


\section{CHAPTER V: CONCLUSION}

This study has attempted to discover the reoccurring themes that dispensationalists used in writing about Mussolini, while identifying the ways those themes paralleled their anxieties and concerns. An exhaustive study of all the individual arguments and speculations would be impossible, but it is worth pointing out that once an Antichrist candidate is identified, the interpretive flexibility inherent to dispensationalism means that there are many opportunities to mine the scriptures for signs that point to a particular person. An internal critic of the excesses of dispensationalist speculation has chalked this up to broader "American democraticindividualistic notions of the clarity of scripture" that are especially well represented among those with eschatological interests. Furthermore, dispensationalists and fundamentalists more generally lack a central source of authority to referee eschatological speculations. Nevertheless, early fundamentalism did possess "a web of mutually legitimating relationships" and there was an interpretative tradition within dispensationalism that provided a general outline. World events and individuals possess varying levels of correspondence to these expectations and Mussolini was an uncommonly good fit for much of his public career. But as circumstances changed, so did perceptions of Mussolini. ${ }^{239}$

Articles on Mussolini in dispensationalist magazines became less common by the end of the 1930s and almost disappeared entirely by WWII. Mussolini's status in secular American circles had diminished considerably due to a variety of reasons, including his invasion of Ethiopia, his growing relationship with Hitler, and an increase in unflattering journalistic portrayals. While his increasingly aggressive imperialism and belligerent attitude helped sustain

\footnotetext{
239 Dale S. Dewitt, Dispensationalist Theology in America during the $20^{\text {th }}$ Century (Grand Rapids, MI: Grace Bible College, 2002), 398; Molly Worthen, Apostles of Reason: The Crisis of Authority in American Evangelicalism (New York: Oxford University Press, 2014), 103.
} 
the perceived link between Mussolini and the Antichrist for dispensationalists, they were not completely immune to these secular attitudes. The Antichrist would be evil, but he also would be omnicompetent. Mussolini increasingly appeared to be subordinate to Hitler and doubts grew about Italy's prowess. As Italy's military misfortunes began to pile up, former boosters of Mussolini "quietly dropped" the topic. ${ }^{240}$

Bauman held out the longest, arguing in 1941 that Mussolini's setbacks may be the head wound that the beast was prophesied to recover from in Revelation. Mussolini's inability to further expand his empire and the exposure of his shortcomings may not be the only explanation, as magazines like The King's Business shifted to more of a this-worldly emphasis right before and during the war. The existence of actual conflict seemed to focus the mind on more immediately pragmatic issues. World events were less likely to be fitted into a prophetic scenario and articles showed more of an emphasis on winning the war and discussing the implications for missionary work when it was done. Articles and books linking Mussolini with the Antichrist disappeared before he was forcibly removed from office and arrested in 1943. When the Nazis rescued him from his mountaintop prison and reinstalled him as the puppet leader of the shortlived Salõ Republic, no one claimed the Antichrist was resuscitated. By 1945, when he was executed by partisans and hung upside down from the girder of a gas station with his mistress Clara Petacci, there apparently was no one left who was surprised that he did not prove to be the "man of sin." After the war, Mussolini was rarely mentioned in dispensationalist sources, and when he was mentioned he was either listed as one in a long line of oppressors who have come and gone or pointed to as a lesson in the futility of arrogance. ${ }^{241}$

\footnotetext{
${ }^{240}$ Wilson, Armageddon Now, 157.

${ }^{241}$ Louis T. Bauman, "Have Mussolini and his 'Resurrected Roman Empire' both Collapsed," King's Business, April 1941, 164. See Revelation 13:3 for the recovery of the beast's head wound; See Dan Gilbert, Significance of the
} 
Premillennial dispensationalists possessed a framework of Biblical interpretation that shaped how they understood the world around them. Because of the ambiguity in some of the prophetic texts, there was a range of possible interpretations and emphases. This meant that dispensationalist prophetic speculations were heavily influenced by the anxieties they felt in their own lives and the problems they saw in their own society. The roughly fifteen-year period that dispensationalists closely tracked Mussolini illustrates this combination of eschatological beliefs with contemporary concerns. His position as the ruler of Rome gave him a leg up as a candidate for the Antichrist, but the intensity of dispensationalist interest was also due to a long list of his characteristics that not only could be made to fit with prophecy but seemed immediately relevant to their own uneasiness with global and domestic changes.

The way dispensationalists evaluate international events and figures cannot be reduced to just a strict eschatological determinism that flows logically from their scriptural interpretations. At the same time, their positions and understandings are not mere reflections of their interests cloaked in an infinitely flexible system of justification. Rather, the dispensationalist viewpoint is determined by a combination of inherited eschatological traditions with contemporary anxieties and concerns. In understanding premillennial dispensationalists of the interwar period, fundamentalists more generally, and current religio-political movements like Christian Zionism, it is important to take both their belief system and their social context seriously.

News, King's Business, April 1942, 124,160 as a representative example of the changed emphasis in fundamentalist periodicals; M.R. DeHaan, The Jew and Palestine in Prophecy (Grand Rapids, MI: Zondervan, 1950), 73. 


\section{BIBLIOGRAPHY}

\section{Primary Sources}

\section{Periodicals}

Advocate

Bible Study for Bereans. https://www.bereanbiblesociety.org/category/bible-study/bible$\underline{\text { study-for-bereans/. }}$

Bridegroom's Messenger

Christian Evangel

Church of God Evangel

Foursquare Crusader

King's Business

Latter Rain Evangel

Moody Institute Monthly

New York Times

Our Hope

Pentecostal Evangel

Sword of the Lord

Sunday School Times

Books, Pamphlets, Cartoons, Radio

Bauman, Louis S. Biblical Prophecy in an Apocalyptic Age: Selected Writings of Louis S. Bauman. Edited by Joel Carpenter. New York: Garland, 1988.

Benham, Charles O. 101 Signs of Christ's Coming: X-Raying Today's Crisis. Joliet, IL: Charles O. Benham, 1937. 
Blackstone, William E. Jesus is Coming. 1908. Reprint, Old Tappan, NJ: Fleming H. Revell Company, 1932.

Brooks, Keith L. The Jews and the Passion for Palestine in the Light of Prophecy. Los Angeles: Brooks, n.d. Prophecy and the Tottering Nations. Los Angeles: Brooks, 1935.

Brown, Arthur I. The Eleventh Hour. Findlay, OH: Fundamental Truth, 1940.

_ I Will Come Again. Findlay, OH: Fundamental Truth, 1947.

DeHaan, M.R. The Jew and Palestine in Prophecy. Grand Rapids, MI: Zondervan, 1950.

Feinberg, Charles Lee. “World's Zero Hour Zech 12 verse 1- ch 13 verse 1Pt. 2," Feinberg Messages. 1976. https://digitalcommons.biola.edu/biola-radio-feinberg/122

Gaebelein, Arno. The Harmony of the Prophetic Word. New York: Fleming H. Revelle, 1904.

_ Half a Century: The Autobiography of a Servant. 1930. Reprint, New York: Garland Publishing, 1988.

The Hope of the Ages: The Messianic Hope in Revelation, in History and in Realization. New York: Our Hope, 1938.

Gray, James M. Satan and the Saint. New York: Fleming H. Revell, 1909.

Hankins, Barry, ed. Evangelicalism and Fundamentalism: A Documentary Reader. New York: New York University Press, 2008.

Lindsey, Hal. The Late, Great Planet Earth. Grand Rapids, MI: Zondervan, 1970.

Michelson, Arthur U. The Jews and Palestine in Light of Prophecy. Los Angeles: Jewish Hope, n.d.

Mussolini, Benito. Fascism: Doctrine and Institutions. Rome: Arditi, 1935. The Corporate State. Firenze, ITL: Vallechi Editore, 1936. 
Morris, Mrs. Mary Winey. Prophecy: What the World is Coming to in the Light of the Book of Revelation. Elgin, IL: Brethren, 1931.

Pace, E.J. The Spirit of Anti-Christ. Pen and Ink on Paper, 1926?, 28.5 x 25 cm, Digital Commons@Biola, https://digitalcommons.biola.edu/ejpace-cartoons/42/.

Pankhurst, Christabel. Pressing Problems of the Coming Age. London: Morgan and Scott, 1924.

The World's Unrest: Visions of the Dawn. London: Morgan and Scott, 1926.

- Seeing the Future. New York: Harper and Brothers, 1929.

— The Lord Cometh. London: Marshal, Morgan and Scott, 1934.

Panton, D.M., James McAlister, and A. Sims, eds. Startling Signs of Great World Changes Soon To Take Place. Toronto: A. Sims, n.d.

Panton, D.M. The Panton Papers. 1928. Reprint, Miami Springs, FL: Schoettle, 1988.

Patmont, Louis Richard. The Mystery of Iniquity: An Expose of the Spirit and Nature of International Communism. Fresno, CA: Graeter, 1933.

Pini, Giorgio. The Official Life of Benito Mussolini. Translated by Luigi Villari. London: Hutchison \& Co., 1939.

Pink, Arthur. The Antichrist. 1923. Reprint, Minneapolis: Klock and Klock, 1979.

Pirolo, Nicholas. Babylon, Political and Ecclesiastical, Showing Characteristics of Anti-Christ and False Prophet Considering Mussolini and the Pope. Milwaukee: Word and Witness, 1937.

Rader, Paul. The Coming World Dictator. N.p .: 1934.

Rice, John R. Bobbed Hair, Bossy Wives and Women Preachers. Murfreesboro, TN: Sword of Lord, 1941. 
Sale-Harrison, L. The Remarkable Jew: His Wonderful Future, God's Great Timepiece. New York: Sale-Harrison, 1934.

Sarfatti, Margherita G. The Life of Benito Mussolini. Translated by Frederic Whyte. New York: Frederick A. Stokes, 1926.

Scofield, C.I., ed. The New Scofield Reference Holy Bible. Rev. ed. New York: Oxford University Press, 1967.

Seldes, George. Sawdust Caesar. New York: Harper and Brothers, 1935.

Smith, Oswald J. When Antichrist Reigns. New York: The Christian Alliance, 1927.

Talbot, Louis. The Coming World Dictator. Glendale, CA: Church Press, n.d.

The Scarlet Woman. Los Angeles: Talbot Publication, n.d.

Trumbull, Charles G. Prophecy's Light on Today. 1937. Reprint, New York: Garland Publishing, 1988.

Winrod, Gerald B. Writings. Wichita, KS: Defender Publishers, 1936.

\section{Secondary Sources}

Alpers, Benjamin, L. Dictators, Democracy, and American Public Culture. Chapel Hill, NC: North Carolina Press, 2003.

Ariel, Yaakov. "Israel in Contemporary Evangelical Christian Millennial Thought." Numen: International Review for the History of Religions 59 (2012): 456-485.

Baker, David. "The Political Economy of Fascism: Myth or Reality, or Myth and Reality?” New Political Economy 11, no. 2 (June 2006): 227-250.

Bergin, Angus. The Great Persuasion: Reinventing Free Markets Since the Depression. Cambridge, MA: Harvard University Press, 2012.

Bosworth, R.J.B. The Italian Dictatorship. New York, Oxford University Press, 1998. 
L Mussolini's Italy: Life Under the Fascist Dictatorship, 1915-1945. New York: Penguin Press, 2006.

Mussolini. New York: Bloomsbury Academic, 2010.

Boyer, Paul. When Time Shall Be No More. Cambridge, MA: Belknap Press, 1992.

Carpenter, Joel A. Revive Us Again: The Reawakening of American Fundamentalism. New York: Oxford University Press, 1997.

Clark, Martin. Mussolini. Harlow, U.K: Pearson, 2005.

Clark, Victoria. Allies for Armageddon: The Rise of Christian Zionism. New Haven: Yale University Press, 2007.

Cole, Stewart G. The History of Fundamentalism. Eugene, OR: Wipf and Stock, 1931.

Cohn-Sherbok, Dan. The Politics of Apocalypse. Oxford: Oneworld, 2006.

Dewitt, Dale S. Dispensationalist Theology in America During the 20 th Century: Theological Development and Cultural Context. Grand Rapids, MI: Grace Bible College, 2002.

Diggins, John Patrick. Mussolini and Fascism: The View from America. Princeton: Princeton University Press, 1972.

Fattorini, Emma. Hitler, Mussolini, and the Vatican: Pope Pius XI and the Speech That was Never Made. Translated by Carl Ipsen. Malden, MA: Polity Press, 2011.

Furniss, Norman F. The Fundamentalist Controversy, 1918-1931. Hamden, CN: Archon Books, 1963.

Fuller, Robert C. Naming the Antichrist. New York: Oxford University Press, 1995.

Gentile, Emilio. The Sacralization of Politics in Fascist Italy. Cambridge, MA: Harvard University Press, 1996.

— The Origins of Fascist Ideology, 1918-1925. New York: Enigma Books, 2005. 
Grem, Darren. The Blessings of Business: How Corporations Shaped Conservative Christianity. New York: Oxford University Press, 2016.

Griffin, Roger. Modernism and Fascism: The Sense of Beginning under Mussolini and Hitler. New York: Palgrave Macmillan, 2007.

Gundle, Stephen, Christopher Duggan, and Guliana Pieri, eds. The Cult of the Duce: Mussolini and the Italians. New York: Manchester University Press, 2013.

Hankins, Barry. God's Rascal: J. Frank Norris and the Beginnings of Southern Fundamentalism. Lexington, KY: University Press of Kentucky, 1996. Jesus and Gin: Evangelicalism, the Roaring Twenties and Today's Culture Wars. New York: Palgrave Macmillan, 2010.

Halsell, Grace. Prophecy and Politics: Militant Evangelists on the Road to Nuclear War. Chicago: Lawrence and Company, 1986.

Hammond, Sarah Ruth. God's Businessmen: Entrepreneurial Evangelicals in Depression and War. Chicago: University of Chicago Press, 2017.

Herf, J. Reactionary Modernism. New York: Cambridge University Press, 1984.

Jackman, David. The Message of John's Letters. Downers Grove, IL: Intervarsity Press, 1988.

David I. Kertzer. The Pope and Mussolini: The Secret History of Pius XI and the Rise of Fascism in Europe. New York: Random House, 2014.

Kiracofe, Clifford A. Dark Crusade: Christian Zionism and US Foreign Policy. New York: I.B. Tauris, 2009.

Krause, C. Norman. Dispensationalism in America. Richmond, VA: John Knox Press, 1958. Laqueur, Walter, ed. Fascism: A Reader's Guide. London: Wildwood House, 1976. 
Palla, Marco. Mussolini and Fascism. Translated by Arthur Figliola and Claudia Rattazzi Papka. New York: Interlink Books, 2000.

Patterson, James Alan. "Changing Images of the Beast: Apocalyptic Conspiracy Theories in American History." Journal of the Evangelical Theological Society 31, no. 4 (December 1988): 443-452.

Paxton, Robert O. The Anatomy of Fascism. New York: Albert A. Knopf, 2004.

Pieterse, Jan Nederveen. "The History of a Metaphor: Christian Zionism and the Politics of the Apocalypse.” Archives de Sciences Sociales des Religions 75 (1991): 75-104. https://www.jstor.org/stable/30116133

Pietsch, B.M. Dispensational Modernism. New York: Oxford University Press, 2015.

Mann, Michael. Fascists. New York: Cambridge University Press, 2004.

Mallett, Robert. Mussolini in Ethiopia, 1919-1935: The Origins of Fascist Italy's African War. New York: Cambridge University Press, 2015.

Marsden, George M. Fundamentalism and American Culture. $2^{\text {nd }}$ ed. New York: Oxford University Press, 2006.

Niebuhr, H. Richard. The Social Sources of Denominationalism. 1929. Reprint, Cleveland: Meridian Books, 1965.

Nelson, Brent F. and James L. Guth, "European Union or Kingdom of the Antichrist? Protestant Apocalyptic Narratives and European Unity," National Identities 19 no. 2 (June 2017): 251-267.

Neville, Peter. Mussolini. New York: Routledge, 2004.

Ribuffo, Leo P. The Old Christian Right: The Protestant Far Right from the Great Depression to The Cold War. Philadelphia: Temple University Press, 1983. 
Salya, Nilay, "Onward Christian Soldiers: American Dispensationalists, George W. Bush and the Middle East," Holy Land Studies 11 no. 2 (2012): 175-204.

Sandeen, Earnest R. The Roots of Fundamentalism: British and American Millenarianism, 18001930. Chicago: University of Chicago Press, 1970.

Sizer, Stephen. Zion's Christian Soldiers? The Bible, Israel and the Church. Nottingham: InterVarsity Press, 2007.

Smith, Denis Mack. Mussolini as a Military Leader. Reading, UK: University of Reading, 1974.

- Mussolini's Roman Empire. New York: Longman, 1976.

Mussolini. New York: Alfred A. Knopf, 1982.

Spector, Stephen. Evangelicals and Israel: The Story of American Christian Zionism. New York: Oxford University Press, 2009.

Sturm, Tristan. "Imagining Apocalyptic Geopolitics: American Evangelical Citationality of Evil Others.” In Mapping the End Times: America Evangelical Politics and Apocalyptic Visions, edited by Jason Dittmer and Tristan Sturm, 133-154. Burlington, VT: Ashgate Publishing, 2010.

Sutton, Mathew Avery, "Was FDR the Antichrist? The Birth of Fundamentalist Antiliberalism in a Global Age," Journal of American History 98, no. 4 (March 2012): 1052-1074.

— American Apocalypse: A History of Modern Evangelicalism. Cambridge, MA: Belknap Press of Harvard University Press, 2014.

Wacker, Grant. Heaven Below: Early Pentecostals and American Culture. Cambridge, MA: University of Harvard Press, 2001.

Weber, Timothy P. Living in the Shadow of the Second Coming: American Premillennialism, 1875-1982. Chicago: University of Chicago Press, 1987. 
On the Road to Armageddon: How Evangelicals Became Israel's Best Friend. Grand Rapids, MI: Baker Academic, 2004.

Wilson, Dwight. Armageddon Now! The Premillenarian Response to Russia and Israel Since 1917. Grand Rapids, MI: Baker Book House, 1977.

Worthen, Molly. Apostles of Reason: The Crisis of Authority in American Evangelicalism. New York: Oxford University Press, 2014. 